Faculdade de Medicina da Universidade de São Paulo Departamento de Patologia Programa de Pós-Graduação em Ciências - Patologia

\title{
AVALIAÇÃO DOS CONSTITUINTES E DO POTENCIAL MUTAGÊNICO DO MATERIAL PARTICULADO ORIUNDO DO BENEFICIAMENTO ARTESANAL DA CASTANHA DE CAJU
}

THIAGO DE MELO CABRAL

São Paulo - SP

2010 


\section{THIAGO DE MELO CABRAL}

\section{Avaliação dos constituintes e do potencial mutagênico do material particulado oriundo do beneficiamento artesanal da castanha de caju}

Tese apresentada à Faculdade de Medicina da Universidade de São Paulo para obtenção do título de Doutor em Ciências

Orientador: Prof. Dr. Paulo Hilário Nascimento Saldiva 
Dados Internacionais de Catalogação na Publicação (CIP)

Preparada pela Biblioteca da

Faculdade de Medicina da Universidade de São Paulo

Creprodução autorizada pelo autor

Cabral, Thiago de Melo

Avaliação dos constituintes e do potencial mutagênico do material particulado oriundo do beneficiamento artesanal da castanha de caju / Thiago de Melo Cabral. -São Paulo, 2010.

Tese(doutorado)--Faculdade de Medicina da Universidade de São Paulo.

Departamento de Patologia.

Área de concentração: Patologia.

Orientador: Paulo Hilário Nascimento Saldiva.

Descritores: 1.Biomassa 2.Anacardium occidentale 3.Genotoxicidade 4.Micronúcleo germinativo 5.Tradescantia 6.Mucosa bucal 7.Material particulado

USP/FM/SBD-108 /10 


\section{FOLHA DE APROVAÇÃO}

Thiago de Melo Cabral

Avaliação dos constituintes e do potencial mutagênico do material particulado oriundo do beneficiamento artesanal da castanha de caju

Tese apresentada a Faculdade de Medicina da Universidade de São Paulo para obtenção do título de Doutor. Área de concentração: Patologia

Aprovado em:

\section{Banca Examinadora}

Prof. Dr. (a).

Instituição: Assinatura:

Prof. Dr. (a).

Instituição: Assinatura:

Prof. Dr. (a). Instituição: Assinatura:

Prof. Dr. (a). Instituição: Assinatura:

Prof. Dr. (a). Instituição: Assinatura: 
"Dedico essa tese aos meus pais, Tarcísio Gondim Cabral e Maria Eunice de Melo Cabral. De forma exemplar, sempre exerceram a função de pai e mãe em plenitude, promovendo uma formação rica em valores morais devido a uma dedicação constante na educação dos seus três filhos". 
"Mais do que de máquinas, precisamos de humanidade. Mais do que de inteligência, precisamos de afeição e doçura. Sem essas virtudes, a vida será de violência e tudo será perdido."

Charles Chaplin

"É Dele a vitória

Alcançada em minha vida"

Frederico Cruz 


\section{AGRADECIMENTOS}

Certamente, para ser correto de verdade, uma parte significativa desse trabalho deveria ser de agradecimentos. Durante esses 36 meses tive a oportunidade de relacionar-me com pessoas incríveis, as quais ficarão para sempre em minha lembrança. Devo o presente trabalho à participação de muitos, desde o mais importante pesquisador, até o mais simples morador da comunidade do Amarelão.

Agradeço a Deus, pela real presença em todos os momentos da minha vida. Guia meus passos, protege o meu caminho e me conforta nos momentos de dificuldade.

A Coordenação de Aperfeiçoamento de Pessoal de Nível Superior (CAPES) pela bolsa de estudos concedida.

Ao Conselho Nacional de Desenvolvimento Científico e Tecnológico (CNPq) pelo financiamento do projeto (Edital MCT - CNPq/CT SAÚDE - 18/2006).

Ao Prof. Dr. Paulo Hilário Nascimento Saldiva por ter aceitado a orientação desse trabalho. Agradeço pelo cuidado que teve comigo. Sempre que necessário atendeu gentilmente as minhas demandas. Sua atitude sempre positiva representa para mim um modelo de como enfrentar as dificuldades. Espero que continue dando oportunidade para estudantes de fora do estado de SP para participar de trabalhos sob sua coordenação. Os resultados desse trabalho têm importante impacto social, e certamente no Brasil ainda existem muitas atividades ou comunidades que necessitam de apoio da sociedade organizada.

A Profa. Dra. Sílvia Regina Batistuzzo de Medeiros, chefe do Laboratório de Mutagênese Ambiental da UFRN, por seu profissionalismo, apoio, estrutura de laboratório e orientação. Sem o seu apoio local e orientação criteriosa não teria sido possível o desenvolvimento desse trabalho. Obrigado pelo auxílio na minha formação, pelos conselhos e pelo companheirismo. Obrigado por tudo!!!

Ao Prof. Dr. Raymundo Soares de Azevedo Neto, coordenador do programa de Pós Graduação em Patologia da FMUSP. Agradeço profundamente a todas as vezes que eu precisei e o senhor efetivamente me ajudou. A sua presença na 
coordenação do programa foi importante para mim desde o momento em que fui contemplado com a bolsa até o momento da defesa.

Ao meu grande amigo e maior parceiro para o desenvolvimento desse trabalho, Marcos Felipe Galvão. Tenho certeza que Deus enviou você para trabalhar comigo porque sabia que sozinho dificilmente eu conseguiria. Passar semanas saindo de casa à 00h00min em busca de fumaça de castanha, dirigindo por estradas perigosas, esburacadas, estradas de barro encharcadas, não é fácil... Meu querido Felipão, obrigado por tudo!!! Obrigado Carolina e desculpa por muitas vezes ter feito você ficar esperando pelo Felipão...

A profa. Dra. Lucymara Fassarela Agnez-Lima, pela sua ajuda sempre que solicitada, por sua qualidade e dedicação exemplares.

Ao Prof. Dr. Fábio Lisboa, pelas oportunidades, pela sua orientação diária, pela amizade, pelo bate papo descontraído... Muito obrigado!!!

As Profas. Dras. Adriana Uchoa e Kátia Scortecci, as quais fazem parte do grupo da Profa. Silvia, e além da saudável convivência, permitiram a realização do estágio em docência nas suas disciplinas.

A Profa. Dra. Cristiane Macedo, por permitir o uso da casa de vegetação do seu laboratório para propagação das mudas de Tradescantia.

Aos pesquisadores pertencentes ao LPAE, Dr. Paulo Afonso, Dra. Miriam Lemos e Dra. Mariangela Macchione, em nome dos quais estendo meus agradecimentos aos demais participantes do grupo.

Aos colaboradores do IAG/USP, Dras. Regina M. de Miranda e Maria de Fátima Andrade.

Agradeço profundamente ao meu pai Tarcísio, minha mãe Eunice, meus irmãos Marcelo e Marcelly. A nossa família é um verdadeiro porto seguro, o que nos dá confiança para sermos ousados.

A minha linda e amada noiva, Débora Aloise, a qual tem reclamado da minha ausência na fase final preparatória para o nosso casamento. Muito obrigado pelo 
companheirismo, carinho, e especialmente pelo seu amor. A sua presença é fundamental em minha vida.

Ao meu querido tio e Prof. Dr. Antonio Cabral Neto e minha prima Zwyla Cabral em nome de quem agradeço aos demais tios e primos.

Mais uma vez, aos meus primos queridos, os quais não citarei devido ao grande número. Primos que tanto torcem por mim, contribuindo de forma significativa na minha motivação pessoal.

Aos grandes amigos que me receberam em São Paulo com muito carinho e cuidado. Tudo teria sido mais difícil sem vocês. Minha querida amiga Dra. Patrícia Estevam dos Santos. Desculpa meus excessos, minha ausência... Cresci muito convivendo com você. Ao seu noivo Marcos Defferrari por ter me acolhido em sua casa em um momento tão importante.

Aos queridos Bebeto e Marcinha, obrigado pelo ambiente familiar e conforto encontrado na casa de vocês.

Aos meus amigos de Laboratório, especialmente Nilmara Alves e mais uma vez meu amigo Felipão. A parceria profissional e amizade verdadeira do nosso trio foi muito importante nesses últimos anos.

Ao meu grande amigo Christian, mesmo você trabalhando muito, como todo paulista, eu sempre sabia que podia contar com você.

Ao meu amigo Garcia Jr. pela amizade e auxílio com os imagens.

A querida Jana Dara que, inicialmente, trabalhou diretamente no nosso projeto e sempre permaneceu contribuindo para o nosso trabalho.

Aos demais colegas de Laboratório, especialmente Lucila, Bia, Débora Afonso, Edson Caio e Daniel. A convivência com vocês permitiu um ambiente fraterno.

Ao Sr. Sebastião Amorim, por ter permitido o uso da sua fazenda para a realização do controle negativo. Aos seus funcionários: Zé Galego e Galeguinho. E seu neto Gustavo A. Abbot pelo incentivo e amizade. 
Aos moradores da comunidade do Amarelão, os quais nos acolhiam em suas palhoças em madrugadas de intenso trabalho. Especialmente a família do casal Sr. Emanoel e Dona Noemia.

Ao meu cunhado Jony Caveira, pela importante dupla que formamos no baralho, brincadeira tão importante para momentos de descontração. A minha cunhadinha Tati Cabral.

A galera da pelada do voleibol, momento mais esperado da semana, onde é possível descarregar as tensões e recarregar as baterias para uma nova semana com muita alegria. Tio Israel, Lucão, Jonas Magia, Gamelão, Marcelos, Daniel Papo Cheio, Eduardo Carniça e demais não listados, mas igualmente importantes.

Aos meus grandes amigos do curso de Biologia: Giva, Tuca, Pedro, Euriel, Delanne, Naissandra e Renata (saudades e carinho).

Aos funcionários da UFRN, especialmente Carmem e Gisele.

Aos funcionários da FMUSP, principalmente a competente secretária da Pós Graduação, Liduvina.

Aos meus amigos não citados, mas que representam parte importante em minha vida.

A Faculdade de Medicina da Universidade de São Paulo (FMUSP), a Universidade Federal do Rio Grande do Norte (UFRN), e ao Programa de Pós Graduação em Ciências com área de concentração em Patologia, pela estrutura física e intelectual. 


\section{AVALIAÇÃO DOS CONSTITUINTES E DO POTENCIAL MUTAGÊNICO DO MATERIAL PARTICULADO ORIUNDO DO BENEFICIAMENTO ARTESANAL

\author{
DA CASTANHA DE CAJU
}

Apesar da importância social e econômica do beneficiamento da castanha de caju para o Rio Grande do Norte, a produção ainda é realizada de forma artesanal. Para a coleta da amêndoa da castanha é necessário assá-la. A fumaça gerada durante a queima da castanha possui altas concentrações de Material Particulado (MP) e esse MP produzido é inalado diariamente por grupos familiares por um período que pode exceder a 10 horas diárias. Em geral, os poluentes atmosféricos oriundos da queima de biomassa são potencialmente nocivos a saúde, relacionando-se com eventos de genotoxicidade, aumento no número de internações hospitalares e ambulatoriais, e mortalidade por doenças cardiovasculares e respiratórias. O presente trabalho teve três objetivos principais: $1^{\circ}$ Realizar medições na concentração de $\mathrm{O}_{3}, \mathrm{NO}_{2}, \mathrm{MP}$, Black Carbon $(B C)$ e composição elementar do MP 2,5 provenientes da queima da castanha. $2^{\circ}$ Identificar 0 potencial mutagênico associado ao beneficiamento artesanal da castanha de caju durante a estação seca, chuvosa e intermediária no RN (Brasil) com o auxílio do teste de micronúcleo (MN) em Tradescantia pallida. $3^{\circ}$ Verificar o efeito mutagênico da atividade em MN de células esfoliadas de mucosa oral de trabalhadores envolvidos no beneficiamento. Para isso, três locais distintos foram definidos como pontos testes: Ponto 1. Comunidade do Amarelão, situada no perímetro rural do município de João Câmara-RN (local onde ocorre a queima da castanha de caju); Ponto 2. Fazenda Santa Luzia, situada próxima à região de queima da castanha de caju (local com as mesma condições ambientais do Ponto 1, porém sem a influência da atividade); Ponto 3. Universidade Federal do Rio Grande do Norte (UFRN), zona urbana de Natal-RN. Os resultados obtidos para o $\mathrm{O}_{3} \mathrm{e} \mathrm{NO}_{2}$ não excederam os limites estabelecidos pela legislação brasileira. No entanto, os resultados da medição de MP obtidos com o medidor portátil "DUSTTRAK ${ }^{\mathrm{TM}}$ Aerossol Monitor" indicou que entre as 8 medições de MP realizadas no Ponto 1, 7 excederam o nível de exposição definido como "estado de emergência" descrito na legislação brasileira $\left(500 \mu \mathrm{g} / \mathrm{m}^{3}\right)$, diferindo significativamente dos resultados obtidos nos Pontos 2 e $3\left(6 \mu \mathrm{g} / \mathrm{m}^{3}\right)$. As avaliações realizadas nos meses de Janeiro, Maio e Setembro de 2009, com o Mini-sampler confirmaram os resultados previamente obtidos com 0 "DUSTTRAK TM Aerossol Monitor". O valor médio de MP 2,5 (Jan - 548,412 $\mu \mathrm{g} / \mathrm{m}^{3}$; Mai - 1022,232 $\mu \mathrm{g} / \mathrm{m}^{3}$; Set - $1291,946 \mu \mathrm{g} / \mathrm{m}^{3}$ ) e BC (Jan - 46,798 $\mu \mathrm{g} / \mathrm{m}^{3}$; Mai 70,068 $\mu \mathrm{g} / \mathrm{m}^{3}$; Set - $69,432 \mu \mathrm{g} / \mathrm{m}^{3}$ ) obtido nas três campanhas para o Ponto 1 foram significativamente maiores que o Ponto 2 e 3. Para o Ponto 1 os elementos $\mathrm{Si}, \mathrm{S}, \mathrm{Cl}$, $\mathrm{K}, \mathrm{Ni}, \mathrm{Cu}$ e $\mathrm{Zn}$ quando presentes estiveram em concentrações superiores aos Pontos 2 e 3. Os testes de genotoxicidade com $T$. pallida indicou aumento significativo no número de $\mathrm{MN}$ em todas as campanhas. Os resultados com células de mucosa oral humana corroboraram com o biomonitor vegetal, sendo verificado aumento significativo na freqüência de $\mathrm{MN}$. Os resultados obtidos caracterizaram um dos piores níveis de exposição humana ao MP já relatado na literatura, excedendo amplamente os limites da legislação brasileira assim como os da OMS. Os resultados obtidos apresentaram um problema ocupacional grave, sendo necessária intervenção imediata dos gestores públicos na tentativa de minimizar os efeitos lesivos da atividade.

Descritores: Queima de biomassa, castanha de caju, genotoxicidade, micronúcleo, Tradescantia, células esfoliadas de mucosa oral e material particulado. 


\section{ASSESSMENT OF THE COMPONENTS AND MUTAGENIC POTENTIAL OF PARTICULATE MATTER FROM ARTISANAL CASHEW NUT ROASTING}

Despite the social and economic importance of the processing of cashew nuts to Rio Grande do Norte, the production is still carried out artisanally. To collect the almond nut is necessary to roasting. The smoke generated during the burning of the nut has high concentrations of particulate matter (PM) and the PM produced is inhaled daily by families for a period which can exceed 10 hours a day. In general, air pollutants come from burning biomass are potentially harmful to health, relating to genotoxicity events, increase in the number of hospitalizations and outpatient, and mortality from cardiovascular and respiratory diseases. This project had three main objectives: 1 Make measurements in the concentration of $\mathrm{O}_{3}, \mathrm{NO}_{2}, \mathrm{MP}$, Black Carbon (BC) and elemental composition of the PM 2.5 from the combustion of the cashew nut. 2 Identify the mutagenic potential associated with artisanally processing of cashew nut during the dry season, wet and intermediate in RN (Brazil) by using a micronucleus (MN) bioassay of T. pallida tetrads. 3 To investigate the effect of mutagenic activity in exfoliated cells of oral mucosa of workers involved in processing. For this, three test sites were chosen for this purpose: Site 1. the Amarelão community - where the roasting occurs, Site 2. the Santa Luzia farm - an area near the roasting site, though without direct influence on the process and Site 3. the Universidade Federal do Rio Grande do Norte (UFRN) - an urban area of Natal, Brazil. The results obtained for the $\mathrm{O}_{3}$ and $\mathrm{NO}_{2}$ do not exceed the limits established by Brazilian legislation. However, the results of the measurement of PM obtained with the portable meter "DUSTTRAK ${ }^{\mathrm{TM}}$ Aerosol Monitor" has indicated that between 8 PM measurements made at Site 1, 7 exceeded the level of exposure defined as "emergency rule" described in the Brazilian legislation $\left(500 \mu \mathrm{g} / \mathrm{m}^{3}\right)$, differing significantly from the results obtained in Sites 2 and $3\left(6 \mu \mathrm{g} / \mathrm{m}^{3}\right)$. Evaluations in January, May and September 2009, with the Mini-sampler confirmed the results previously obtained with the "DUSTTRAK TM Aerosol Monitor. The average value of $2.5 \mathrm{MP}$ (Jan - $548.412 \mathrm{mg} / \mathrm{m}^{3}$; May $1022.232 \mathrm{mg} / \mathrm{m}^{3}$; Set - $1291.946 \mathrm{mg} / \mathrm{m}^{3}$ ) and BC (Jan - $46.798 \mathrm{mg} / \mathrm{m}^{3}$; May $70.068-\mathrm{mg} / \mathrm{m}^{3}$; Set $-69.432 \mathrm{mg} / \mathrm{m}^{3}$ ) obtained in the three campaigns for Site 1 were significantly higher than the Site 2 and 3 . To the Site 1 the elements $\mathrm{Si}, \mathrm{S}, \mathrm{Cl}$, $\mathrm{K}, \mathrm{Ni}, \mathrm{Cu}$ and $\mathrm{Zn}$ when present were at concentrations higher than the Sites 2 and 3. Genotoxicity tests with $T$. pallida showed a significant increase in the number of $\mathrm{MN}$ in all campaigns. The results with cells of human oral mucosa have confirmed the biomonitoring, and found significant increase in the frequency of MN. The results marked one of the worst levels of human exposure to PM has been reported in the literature and greatly exceeded the limits of the Brazilian legislation as well as the $\mathrm{WHO}$. The results showed a serious occupational problem, requiring immediate intervention of public officials in an attempt to minimize the harmful effects of the activity.

Descriptores: Biomass burning, cashew nut, genotoxicity, micronuclei, Tradescantia, exfoliated buccal cells and particulate matter (PM) 
RESUMO Erro! Indicador não definido.

ABSTRACT ix

LISTA DE TABELAS ................................................................................ xiii

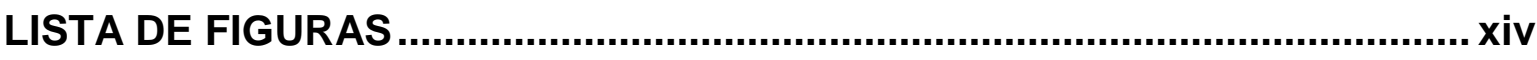

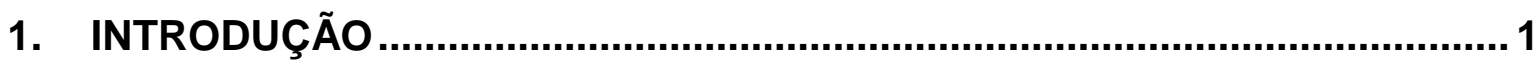

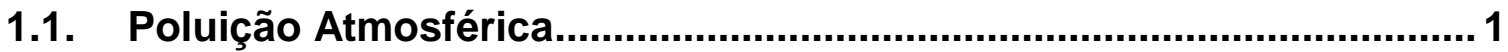

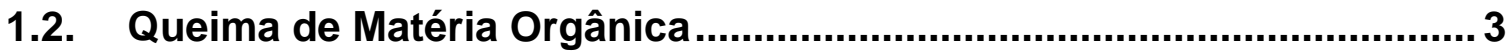

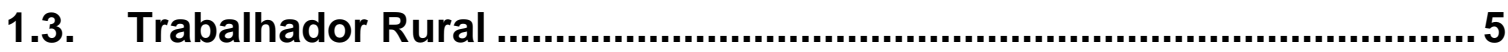

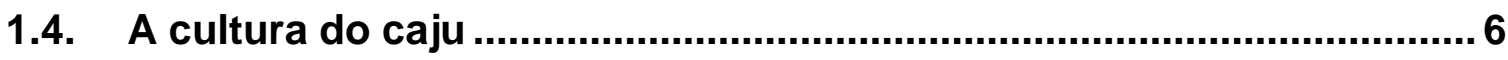

1.5. Indicadores de exposição a poluentes ambientais ............................ 12

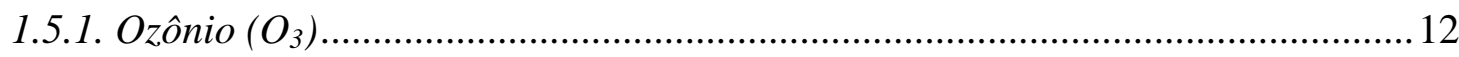

1.5.2. Dióxido de Nitrogênio (NO2) ..........................................................................13

1.6. Identificação e composição do Material Particulado .......................... 15

1.7. Composição Elementar do Material Particulado......................................17

1.8. Genotoxicidade e monitoramento biológico ..........................................17

1.9. Testes utilizados na detecção de genotoxicidade.................................. 20

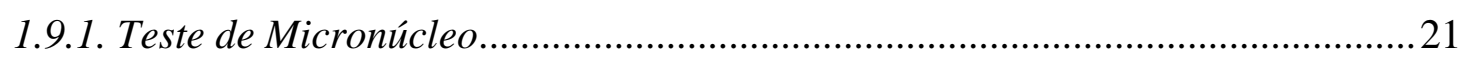

1.9.1.1. Micronúcleo em Tétrades de Tradescantia pallida ...........................................21

1.9.1.2. Micronúcleo em mucosa oral humana …………………………………......22

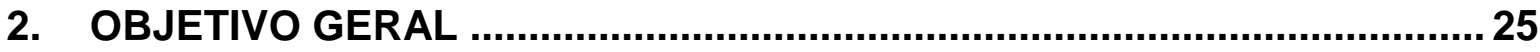

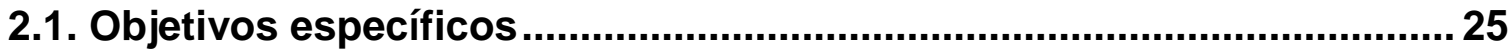

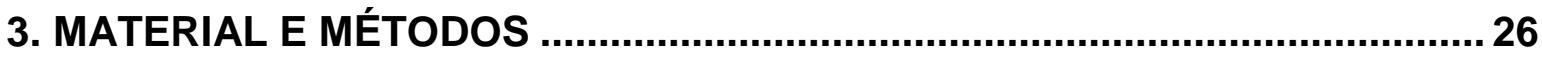

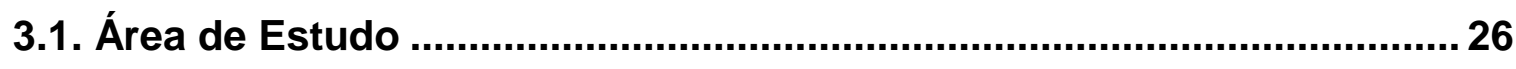

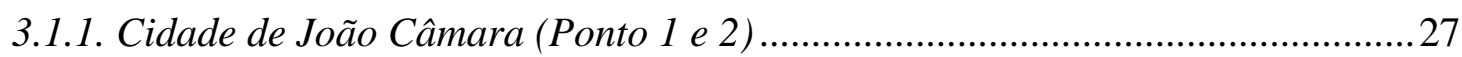

3.1.2. Comunidade do Amarelão - Local onde ocorre o beneficiamento da Castanha

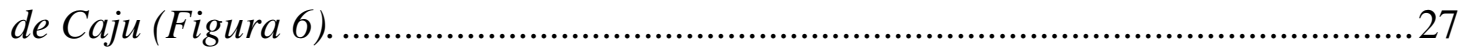

3.1.3. Fazenda Santa Luzia - Próximo ao local de beneficiamento da Castanha de caju, mas sem influencia da atividade ...................................................................29

3.1.4. Município de Natal - Sem influencia da queima da castanha de caju. .............29

3.2. Indicadores de exposição a poluentes ambientais ................................... 31

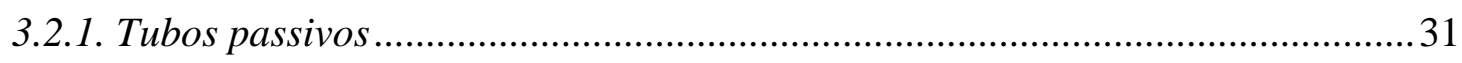

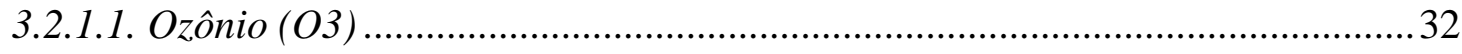


3.2.1.2. Dióxido de Nitrogênio (NO2) (James P. Lodge 1988).

3.2.2. Quantificação do material particulado com o uso de amostradores ativos........34

3.2.2.1 DUSTTRAK ${ }^{\mathrm{TM}}$ Aerossol Monitor (MP 10ųm, 2,5um e 1,0um) ..........................34

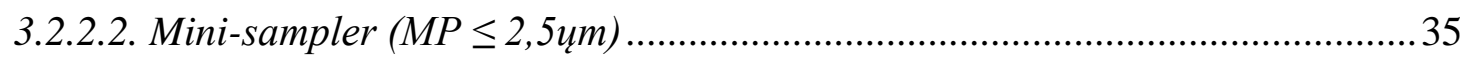

3.2.3. Análise da composição do MP acumulado nos filtros de policarbonato .............36

3.3. Classificação e caracterização da espécie utilizada como biomonitor Tradescantia pallida (Rose) D.R. Hunt. Var. purpúrea.................................38

3.4. Testes de genotoxicidade ........................................................................ 39

3.4.1. Teste de Micronúcleo em T. pallida (Ma 1981; Ma et al. 1994b).......................39

3.4.2. Teste de Micronúcleo em mucosa oral humana (Holland et al. 2008) ..............42

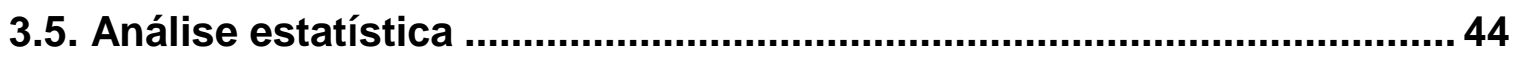

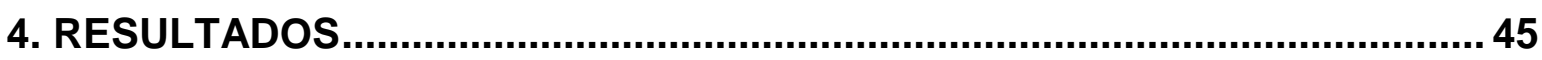

4.1. Indicadores de exposição a poluentes ambientais ............................... 45

4.1.1. Ozônio (O3) e Dióxido de Nitrogênio (NO2) .......................................................45

4.2. Quantificação do material particulado (MP 10 ųm, 2,5 ųm e 1,0 ųm) .... 47

4.3 Análise da composição do Material Particulado acumulado nos filtros de policarbonato pelo Mini-sampler (MP 2,5 ųm) ....................................... 49

4.4. Teste de Micronúcleo em T. pallida ..................................................... 58

4.5. Teste de micronúcleo em mucosa oral de humanos..............................61

4.5.1. Características dos participantes.....................................................................61 61

4.5.2. Número de micronúcleo em mucosa oral humana ............................................62 62

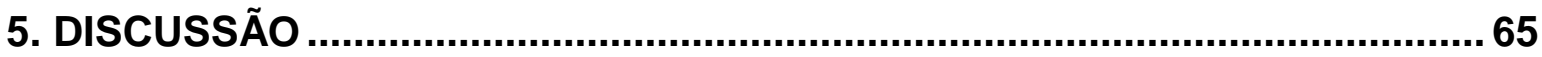

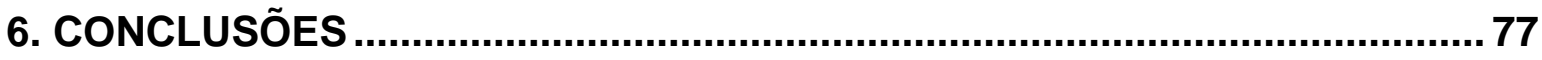

7. PERSPECTIVAS E RECOMENDAÇÕES ....................................................... 79

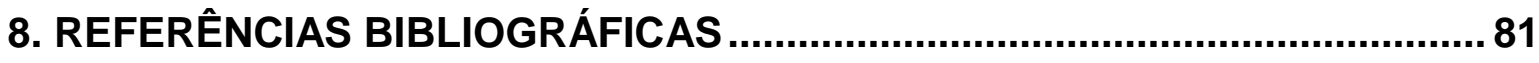

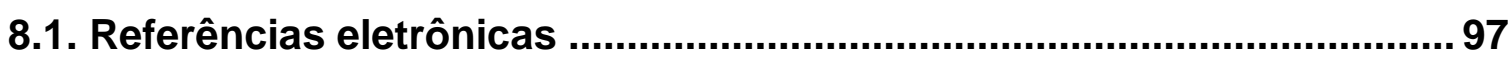

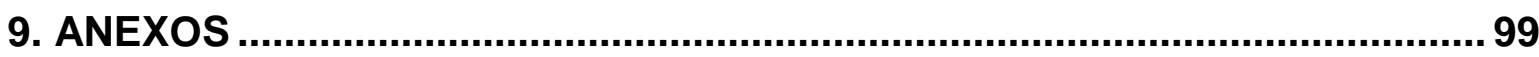




\section{LISTA DE TABELAS}

Tabela 1. Medições da concentração de $\mathrm{O}_{3}$ e $\mathrm{NO}_{2}$ para os meses de Janeiro, Maio e Setembro de 2009, relativo à quantidade de elemento acumulado por área do filtro $\left(\mu \mathrm{g} / \mathrm{m}^{3}\right)$ em um dia de exposição. A tendência central dos resultados foi apresentada como Mediana e Média e a dispersão como Distância Interquartílica (IQR) e Desvio Padrão (DP). O Ponto 1 representa a Comunidade do Amarelão, Ponto 2 a Fazenda Santa Luzia e o Ponto 3 a UFRN.

Tabela 2. Medições de MP 1,0 ųm, 2,5 ųm e 10 ųm realizados nos Pontos 1, 2 e 3 , bem como os limites presentes na legislação brasileira estabelecidos pela resolução no 03 do CONAMA (CONAMA 003/1990) e níveis máximos presente nas orientações da Organização Mundial de Saúde (WHO 2005b). Ponto 1 representa a Comunidade do Amarelão, Ponto 2 a Fazenda Santa Luzia e o Ponto 3 a UFRN.

Tabela 3. Medições da concentração de material particulado na fração respirável (MP 2,5), Black Carbon e composição elementar para os meses de Janeiro, Maio e Setembro de 2009. A tendência central dos resultados foi apresentada como Mediana e Média, e a dispersão como Distância Interquartílica (IQR). O resultado corresponde a quantidade de elemento acumulado por área do filtro $\left(\mu \mathrm{g} / \mathrm{m}^{3}\right)$. Ponto 1 representa a Comunidade do Amarelão, Ponto 2 a Fazenda Santa Luzia e o Ponto 3 a UFRN.

Tabela 4. Correlação de Spearman para os elementos acumulados nos filtros de policarbonato pelo Mini-sampler no Ponto 1

Tabela 5. Correlação de Spearman para os elementos acumulados nos filtros de policarbonato pelo Mini-sampler no Ponto 2

Tabela 6. Correlação de Spearman para os elementos acumulados nos filtros de policarbonato pelo Mini-sampler no Ponto 3.

Tabela 7. Freqüência média e desvio padrão do número de micronúcleos encontrados em tétrades de $T$. pallida no biomonitoramento realizado nos meses de setembro (2008), Janeiro, Maio e Setembro (2009). Os dados são relativos ao 
número de micronúcleos encontrados em cada 100 tétrades analisadas. Ponto 1 representa a Comunidade do Amarelão, Ponto 2 a Fazenda Santa Luzia e o Ponto 3 a UFRN.

Tabela 8. Principais características e número de $\mathrm{MN}$ encontrados nos trabalhadores do beneficiamento da castanha de caju e indivíduos pertencentes ao grupo controle.

\section{LISTA DE FIGURAS}

Figura 1. Desenho esquemático dos tecidos da castanha de caju.

Figura 2. Processo de beneficiamento da castanha de caju amplamente desenvolvido na comunidade do Amarelão. a e b - Palhoças utilizadas como local de beneficiamento da castanha de caju; c - Grupo familiar envolvido com a atividade; $\mathbf{d}$ - Panela utilizada para o cozimento da castanha de caju, chamado de "caco" pelos beneficiadores; e - Etapa final do beneficiamento (retirada da última pele da amêndoa). $\mathbf{f}$ - Caminhão usado para transportar a castanha beneficiada na comunidade do Amarelão para centros de comercialização.

Figura 3. Distribuição do $M P$ nas vias aéreas. $O M P \geq 10 \mu \mathrm{m}$ é retido entre o nariz e a boca. MP $10 \mu \mathrm{m}$ ultrapassa a laringe e penetra na traquéia e brônquios. MP 2,5 $\mu \mathrm{m}$ chega aos alvéolos pulmonares. Figura original (Donaldson et al. 2001; Cormier et al. 2006)

Figura 4. Estrutura e diferenciação do epitélio oral. A - Fotomicrografia do epitélio de mucosa oral humana mostrando as diferentes camadas de células do epitélio e o tecido conjuntivo subjacente. O epitélio oral é classificado como epitélio escamoso estratificado. (i) Camada de células esfoliada; (ii) Estrato espinhoso; (iii) Estrato basal; (iv) "Rete pegs" - extensões epiteliais que se projetam no tecido conjuntivo; (v) Lâmina própria - tecido conjuntivo. B - Desenho esquemático ilustrando as camadas do epitélio da mucosa oral: Células esfoliadas, estrato espinhoso e estrato basal.

Figura original (http://www.eastman.ucl.ac.uk/cal/ulcerspath/healthy.htm). Retirada de Holland et al. 2008, com adaptações. 
Figura 5. Mapa da área de estudo. O número "1" indica o local correspondente à comunidade do Amarelão (onde ocorre o beneficiamento da castanha de caju); o número "2" indica a localização da Fazenda Sta. Luzia; o número 3 corresponde a cidade de Natal, onde está localizada a UFRN. O sentido predominante do vento nos três pontos é Sudeste (SE) (Anexo II)

Figura 6. a - Grupos de trabalhadores da comunidade do amarelão em palhoças usadas para o beneficiamento. b - Crianças brincando entre as casas da Comunidade do Amarelão

Figura 7. a e b - Fazenda Santa Luzia (Ponto 2). O local apresenta condições ambientais semelhantes à comunidade do Amarelão, mas sem influencia da atividade do beneficiamento da castanha de caju.

Figura 8. a e b - Tubos passivos contendo filtros absorventes para avaliação da concentração de $\mathrm{O}_{3}$ e $\mathrm{NO}_{2}$. $\mathbf{b}$ - Em vermelho - destaque para um tubo passivo.

Figura 9. Montagem dos tubos passivos. a - $\mathrm{O}$ filtro de $\mathrm{O}_{3}$ apresenta coloração azul; $\mathbf{b}$ - filtro de $\mathrm{NO}_{2}$ apresenta cor branca

Figura 10. a - "DUSTTRAK ${ }^{\mathrm{TM}}$ Aerossol Monitor" posicionado próximo aos trabalhadores; b - Equipamento apresentando o monitor digital com resultado da medição do MP

Figura 11. "Mini-sampler". a - Amostrador ativo destacando os diferentes componentes constituintes do equipamento (NEP/LPAE-FMUSP 2008). b Equipamento posicionado próximo aos trabalhadores do beneficiamento artesanal da castanha de caju.

Figura 12. Tradescantia pallida (Rose) D.R. Hunt var. purpúrea.

Figura 13. a - Floreiras contendo os diferentes compostos utilizados na preparação do solo; $\mathbf{b}$ - Casa de vegetação onde foi realizada a propagação das mudas antes do período experimental; c - Mudas prontas para serem levadas para campo

Figura 14. Esquema da preparação citológica. Adaptado de Ma (1981). 
Figura 15. Coleta de células de mucosa oral humana realizada na Comunidade do Amarelão em beneficiadores da castanha de caju

Figura 16. Filtros de policarbonato usado no Mini-sampler após campanha de exposição nos três pontos teste. a - Corresponde a comunidade do Amarelão (Ponto 1); b - Corresponde ao ponto UFRN (Ponto 3); c - Corresponde a Faz. Sta. Luzia (Ponto 2)

Figura 17. Microscopia óptica $(400 \mathrm{X})$ de tétrades de $T$. pallida corada com acetato de carmim a $2 \%$. a - Tétrade de $T$. pallida sem a presença de micronúcleos. $\mathbf{b}$ - Tétrade com dois micronúcleos

Figura 18. a - Gráfico apresentando a freqüência média e desvio padrão do número de micronúcleos encontrados em tétrades de T. pallida em cada 100 tétrades analisadas durante o biomonitoramento. P1 representa a Comunidade do Amarelão; P2 a Fazenda Sta. Luzia; P3 a UFRN. b - Gráfico de valores individuais: Cada ponto vermelho indica um valor individual encontrado na amostra e o ponto azul a média dos resultados em cada amostra. S1, S2 e S3 representam o P1, P2 e P3 respectivamente.

Figura 19. Microscopia óptica $(400 \mathrm{X})$ de células esfoliadas de mucosa oral humana coradas com reativo de Shiff. a - Seta indica a presença de micronúcleo; b - células esfoliadas sem a presença de micronúcleos

Figura 20. a - Gráfico apresentando a freqüência média e desvio padrão do número de micronúcleos encontrados em células de mucosa oral em cada 1000 células analisadas nos indivíduos pertencentes ao grupo teste e ao grupo controle. b - Gráfico de valores individuais: Cada ponto vermelho indica um valor individual encontrado na amostra; o ponto azul indica a média dos resultados em cada amostra. Site 1 e Control representam o grupo teste e o grupo controle respectivamente. 


\section{INTRODUÇÃO}

\subsection{Poluição Atmosférica}

A poluição ambiental representa um dos maiores problemas da atualidade. A contaminação do ar, do solo e da água tem influencia direta na vida dos organismos. Como poluente atmosférico pode ser classificado toda e qualquer forma de matéria ou energia com intensidade e em quantidade, concentração, tempo ou características em desacordo com os níveis estabelecidos em legislação, e que tornem ou possam tornar o ar impróprio, nocivo ou ofensivo à saúde, inconveniente ao bem-estar público, danoso aos materiais, à fauna e à flora ou prejudicial à segurança, ao uso e gozo da propriedade e às atividades normais da comunidade (CONAMA 003/1990).

A atmosfera é uma fina camada de gases, partículas e nuvens ao redor do planeta. A atmosfera é subdividida em camadas menores, sendo a troposfera a camada que interage com os organismos. Essa camada se inicia da superfície da terra, e termina na camada limítrofe, chamada tropopausa, logo abaixo da estratosfera, apresentando uma espessura que pode variar de 10 - $15 \mathrm{Km}$ (Simoneit 2002).

Anualmente são depositados bilhões de toneladas de poluentes na atmosfera terrestre. As principais fontes de poluentes incluem a combustão de combustíveis fósseis, cozinhar com combustíveis sólidos e a queimada de florestas (Ramanathan \& Feng 2009). Em geral, a concentração de poluentes na atmosfera é bastante dinâmica, onde ocorre constantemente a emissão de partículas poluidoras a partir de fontes naturais ou oriundas de atividades humanas, e a limpeza pela ação principalmente de eventos naturais como chuva, granizo, neblina e cerração.

Os poluentes podem ser classificados como primários e secundários. Os primários são aqueles lançados diretamente no ar. E os secundários são os que se formam por meio de reações que ocorrem entre poluentes primários e componentes naturais da atmosfera. Durante a queima de biomassa, muitos gases são produzidos diretamente, como por exemplo: o gás carbônico $\left(\mathrm{CO}_{2}\right)$, monóxido de carbono $(\mathrm{CO})$, hidrogênio molecular $\left(\mathrm{H}_{2}\right)$ e óxido nítrico (NO). Na atmosfera, os componentes primários podem interagir formando os componentes secundários, como o peróxido 
de hidrogênio $\left(\mathrm{H}_{2} \mathrm{O}_{2}\right)$, ácido sulfúrico $\left(\mathrm{H}_{2} \mathrm{SO}_{4}\right)$, ácido nítrico $\left(\mathrm{HNO}_{3}\right)$ e o ozônio $\left(\mathrm{O}_{3}\right)$ (WHO 2004).

O acúmulo de gases poluentes na atmosfera tem sido a razão de acordos internacionais. Liderado pela Organização das Nações Unidas (ONU), governos de todos os continentes têm se reunido para definir metas de redução de emissão de gases poluidores, com o objetivo de evitar o aquecimento global e promover o desenvolvimento dos países de forma sustentável (ONU, 1992). Gases como o dióxido de carbono $\left(\mathrm{CO}_{2}\right)$, o metano $\left(\mathrm{CH}_{4}\right)$, o óxido nitroso $\left(\mathrm{N}_{2} \mathrm{O}\right)$, o hidrofluorcarbonos (HFCs), o perfluorcarbonos (PFCs) e o hexafluoreto de enxofre $\left(\mathrm{SF}_{6}\right)$, podem formar uma camada de poluentes de difícil dispersão, causando o efeito estufa. O efeito estufa é um fenômeno onde os gases poluentes atuam como um isolante térmico, e consequentemente o calor fica retido nas camadas mais baixas da atmosfera causando aumento da temperatura do planeta. Esses gases absorvem grande parte da radiação infravermelha emitida pela terra, dificultando a dispersão do calor. Como conseqüência do efeito estufa é possível observar o aquecimento global, causador de graves alterações de grande amplitude, tal como o derretimento das calotas polares, o aumento do nível dos oceanos, o surgimento de desertos, e alterações tanto no comportamento quanto na taxa de sobrevivência dos organismos (Ramanathan \& Feng 2009).

Atualmente, além dos gases do efeito estufa, diversos trabalhos têm apontado os componentes presentes no aerossol atmosférico com relevância para as alterações climáticas. O material particulado (MP) presente no aerossol possui capacidade de refletir ou absorver a luz, e consequentemente alterar a radiação incidente no planeta ou a dispersão do calor, respectivamente. $O$ aerossol pode ser definido como uma complexa mistura de componentes orgânicos e inorgânicos, apresentando-se tanto no estado líquido quanto sólido, e se encontrando disperso em um meio gasoso. As partículas em suspensão variam quanto ao tamanho, composição e origem (McMurry 2000), possuindo grande importância na saúde dos organismos (WHO 2003).

Devido à complexidade em termos de composição química e propriedades físicas, o material particulado tem sido relacionado com diversas alterações fisiológicas e por isso demanda importantes estudos os quais visem identificar 
principalmente qual a fonte de emissão, as características físicas e químicas do MP, assim como qual o efeito da interação do MP com o meio ambiente e na saúde das pessoas (WHO 2003). Em conjunto, os poluentes atmosféricos estão relacionados com a irritação de mucosas e vias respiratórias, cânceres, corrosões de construções e monumentos, alteração da água e solo, inversão térmica, efeito estufa e destruição da camada de ozônio. Atualmente, acredita-se que a estabilização do clima do planeta com a redução dos níveis de poluentes apenas será possível com a cooperação internacional (Clarke et al. 2009).

\subsection{Queima de Matéria Orgânica}

Diariamente diversos poluentes são lançados livremente na atmosfera. Em geral, associamos a poluição atmosférica ou ao efeito da queima de combustível de automóveis ou a ação de grandes indústrias localizadas em alguns pólos regionais. No entanto, diversas outras atividades relacionadas à queima de biomassa contribuem de maneira significativa para a qualidade do ar, atingindo preferencialmente os países em desenvolvimento (Costa \& Dreher 1997; Medeiros et al. 2004; Carvalho-Oliveira et al. 2005a).

As emissões da queima de biomassa, como madeira, papel, incêndios florestais, dejetos agrícolas, tabaco e cozinhar são caracterizados pela alta emissão de carbono orgânico e MP quando comparadas com a emissão de combustíveis fósseis. A queima de biomassa em condições de queima pouco controlada produz muita fuligem e MP que podem ser vistos como uma nuvem de fumaça, produzindo monóxido de carbono (CO), óxido nítrico (NO), metano $\left(\mathrm{CH}_{4}\right)$, compostos orgânicos voláteis (VOCs - como o benzeno) e compostos orgânicos semi-voláteis (como hidrocarbonetos policíclicos aromáticos - HPAs). Alguns dos componentes produzidos são persistentes, bioacumulativos e tóxicos, incluindo o hexaclorobenzeno e alguns HPAs como o benzopireno. Os poluentes produzidos podem se dispersar e interferir na água, no solo e na vida dos organismos (Lemieux et al. 2004). Especificamente, a queima de material vegetal geralmente emite, proporcionalmente, menos Black Carbon $(B C)$ do que a fuligem do diesel e outras emissões de combustíveis fósseis. A combustão de biomassa vegetal tende a ter maiores emissões de orgânicos derivados 
da combustão de lignina e celulose que diferem dos marcadores encontrados nas emissões de combustíveis fósseis (Lewtas 2007; Simoneit 2002).

No Brasil, estudos relacionados com a queima de biomassa vegetal têm sido realizados principalmente relativos a queimadas de florestas ou atividades industriais como o processamento da cana de açúcar (Artaxo \& Hansson 1995; Allen et al. 2004; Guyon et al. 2004; Lara et al. 2005). Entre as condições de se detectar o potencial poluidor da queima de biomassa em ambientes abertos, existe certa dificuldade na aquisição da amostra para uma estimativa real da atividade. A estimativa da atividade depende da fonte e da freqüência de queima, e desse modo, atividades realizadas de forma pouco controlada ou de freqüência irregular não favorece o planejamento de execução da avaliação.

Tradicionalmente, análises químicas dos componentes dispersos auxiliam na identificação e conseqüente classificação do risco à saúde humana considerando a exposição ao composto identificado. Nesse contexto, diversos produtos que são gerados durante a queima de biomassa podem apresentar efeitos sobre a saúde da população exposta (Ward \& Hardy 1991; Morawska \& Zhang 2002). Contudo, a maioria da exposição química ocupacional e ambiental é de mistura complexa, e não de agentes individualizados. Devido à complexidade causada pela interação dos agentes químicos, os efeitos biológicos não podem ser caracterizados simplesmente por análises tradicionais (Zagatto \& Bertoletti 2006). Sinergia e antagonismo que ocorrem como resultado da complexidade dos compostos químicos confere características específicas às misturas e estão entre os aspectos que devem ser considerados nas avaliações toxicológicas (Muller et al. 2002; WHO 2003). Portanto, para que seja avaliado de forma ampla o efeito dos poluentes oriundos da queima de biomassa sobre trabalhadores é necessária a realização de análises químicas e biomonitoramento para a detecção dos níveis de poluentes e do efeito desses agentes sobre os organismos. 


\subsection{Trabalhador Rural}

Em geral, o tema das condições de vida, trabalho, saúde e doença dos trabalhadores rurais no Brasil evocam estereótipos, e entre eles a associação com atividades rudimentares, trabalhadores empobrecidos, socialmente marginalizados e intoxicados pelos agrotóxicos. Entretanto, apesar da veracidade e dessa realidade ser ainda muito freqüente em nosso meio, é necessário romper com o reducionismo e conhecer melhor o problema na perspectiva da mudança desse quadro (Dias 2006).

As atividades econômicas ligadas ao campo ou ao meio rural têm raízes profundas na história brasileira. Apesar do intenso processo de industrialização promovido pelas políticas públicas a partir de meados dos anos 40 , do século passado e da acelerada migração rural-urbana que acompanhou esse processo, a produção e atividades rurais têm grande importância no país, contribuindo ainda hoje com fatia expressiva do Produto Interno Bruto (PIB) brasileiro. Segundo os dados divulgados pelo Instituto Brasileiro de Geografia e Estatística (IBGE) em maio de 2005, o crescimento do PIB no primeiro trimestre de 2005 foi de 0,3 \% em relação ao último trimestre de 2004 e que o setor que apresentou o melhor desempenho no trimestre avaliado foi o agropecuário, com um crescimento de 2,6\%. Enquanto a área cultivada expandiu 16,1\% no país, entre 1990 e 2003, a produção de grãos mais que duplicou, passando de 59 milhões de toneladas para 125 milhões (IBGE 2007b). No ano de 2008 o valor da produção da agricultura brasileira cresceu $27,3 \%$, com relação a 2007 (IBGE, 2009).

O nordeste brasileiro é uma das regiões mais pobres do Brasil, sendo caracterizada por períodos de fortes secas, os quais anualmente flagelam milhares de nordestinos com a falta de água. A falta de água, e conseqüentemente a ausência de emprego e renda, tornam parte dessa população permissiva a qualquer atividade que possa ser desenvolvida durante 0 ano inteiro promovendo o sustento das famílias. Nesse contexto, o beneficiamento da castanha de caju é uma alternativa socialmente e financeiramente viável, pois além de poder ser desenvolvida por todos os membros de uma família, é um produto facilmente comercializável. Em geral, a atividade pode ser desenvolvida durante o ano inteiro, onde mesmo nos períodos de seca, a castanha produzida no período de safra pode ser acondicionada e processada durante a entressafra. Contudo, a falta de assistência aos trabalhadores, a 
informalidade da atividade e a falta de conhecimento da sociedade em geral sobre as condições em que é desenvolvido o beneficiamento da castanha de caju inibem qualquer forma de controle dos potenciais efeitos lesivos a saúde associada ao trabalho.

No estado do Rio Grande do Norte $(R N)$, o trabalho infantil tem sido apresentado como um importante problema da atividade rural, especialmente desde a divulgação dos resultados da Pesquisa Nacional por Amostra de Domicílios (PNAD), do IBGE em 2007 (IBGE 2007a). No RN, de 2001 para 2004, houve redução no número de pessoas trabalhando na faixa etária dos 5 aos 14 anos. Esse número passou de 43. 106 para 33. 815 no período de 2001 a 2002. No ano seguinte, reduziu para 33. 722, e em 2004 esse número foi equivalente 31. 828. Mas em 2005, segundo o PNAD, voltou a subir e ficou em 43. 395, superando o valor encontrado em 2001. Entre as crianças de 5 a 9 anos, faixa etária em que o trabalho infantil é mais aviltante, o índice cresceu 63\% de 2002 para 2005. Atualmente, o RN é o 12 estado do país com maior incidência de trabalho infantil (IBGE 2007a). No ano de 2006, um dos principais jornais do estado (Porpino, 2006), destacou o resultado do PNAD e a relação com a atividade do beneficiamento da castanha desenvolvida na comunidade do Amarelão. Foi informado ainda que, nessa atividade, os dados de trabalho infantil podem ainda ser maiores devido à subnotificação. $E$ destacou que quando uma empresa é flagrada com crianças trabalhando, o Ministério do Trabalho aplica penas administrativas e multas trabalhistas. No caso do trabalho doméstico a ação é restrita. "Os pais podem perder o direito de ficar com a criança para uma instituição ou para pais adotivos, mas essa é uma medida extrema".

\subsection{A cultura do caju}

O cajueiro (Anacardium occidentale) é uma típica árvore originária do Norte e Nordeste brasileiro. É uma planta perene, de ramificação baixa e porte médio cuja copa atinge, no tipo comum, altura média de cinco a oito metros e diâmetro médio entre $12 \mathrm{~m}$ e $14 \mathrm{~m}$. O cajueiro apresenta em uma mesma inflorescência flores masculinas e hermafroditas. As masculinas abrem-se das 06:00 horas até as 16:00 horas, e as hermafroditas das 10:00 horas até as 12:00 horas. A receptividade do órgão reprodutor feminino ocorre desde 24 horas antes até as 48 horas depois da 
abertura da flor, predominando a polinização cruzada. A frutificação dá-se na época seca decorrendo 60-65 dias da floração à frutificação completa (Oliveira \& Rocha 2009).

O caju é um pseudofruto, que é o suporte da verdadeira fruta "a castanha". Tanto o pseudofruto quanto a amêndoa da castanha são produtos de alto valor nutritivo, além de apresentarem diversas possibilidades de aproveitamento dos seus derivados. O pseudofruto é a parte carnosa ligada ao fruto (é o pedúnculo floral hipertrofiado) que pode ser consumido in natura ou utilizado na produção de doces, geléias, polpas para sucos ou outras bebidas. A castanha é um aquênio reniforme constituído pelo pericarpo (formado pelo epicarpo e mesocarpo) e o endocarpo (amêndoa) comestível. A castanha é geralmente consumida após o cozimento, e é o produto de maior retorno financeiro.

Vários países do mundo atuam na produção de castanha de caju. Os maiores produtores são países pobres, e por isso existe uma necessidade maior de investigações em torno do processo produtivo. A Índia, Vietnã e o Brasil são os maiores produtores mundiais de castanha de caju e em 2005 produziram respectivamente $585.805,335.181$ e 187.129 toneladas. Além desses três países, vários outros do continente africano contribuem para a produção mundial: Nigéria, Benin, Ghana, Costa do Marfim, Burkina Faso, Guiné Bissau, Moçambique, Tanzânia e Kenia (FAO 2008).

Segundo o censo agropecuário do IBGE o estado do Rio Grande do Norte (RN) ocupa a segunda colocação na produção brasileira de castanha de caju, com uma produção média em torno de 47.862 toneladas de castanha em uma área cultivada de 114.754 ha. De acordo com os dados da SEDEC/RN, entre os anos de 2005 e 2006, a castanha de caju foi o segundo produto mais exportado pelo RN, com um volume de exportação em torno de 45,5 milhões de dólares (IBGE 2006). Sendo o Canadá, Estados Unidos e países da Europa os principais destinos da castanha produzida no $\mathrm{RN}$.

A cultura do caju encontra-se em ampla expansão no Rio Grande do Norte, principalmente por ser uma cultura perene, isto é, tem a capacidade de sobreviver a anos de seca. A cajucultura conta com um grande apoio do Governo do Estado, visto que gera emprego, renda e melhoria da qualidade de vida dos produtores, sobretudo 
na região do Semi-árido, além de contribuir para a riqueza do estado, já que $80 \%$ da sua produção é exportada.

A área cultivada de cajucultura no RN é superior a 120.000 ha, concentrandose mais de $96 \%$ em propriedades de até 100 ha. A produtividade em média de caju está entre $340 \mathrm{~kg} / \mathrm{ha}$ e $350 \mathrm{~kg} / \mathrm{ha}$. Segundo a EMPARN (Empresas de Pesquisa Agropecuária do Rio Grande do Norte), esta produtividade pode melhorar com a aplicação de inovações tecnológicas simples (Fernandes et al. 2009).

O Estado do RN vem beneficiando vários municípios (12) através de um projeto de revitalização de mini fábricas de castanha de caju e conta com o apoio de várias instituições como: SEBRAE/RN, Banco do Brasil S/A, EMPARN, EMATER - Empresa de Assistência Técnica e Extensão Rural e INCRA - Instituto Nacional de Colonização e Reforma Agrária.

Um dos maiores problemas da cadeia produtiva do caju são as condições na qual ocorre a queima da castanha para se obter a amêndoa (subproduto de maior valor). Para a preparação das castanhas é necessário assá-las em forno, onde a própria casca da castanha obtida durante 0 beneficiamento funciona como combustível. Segundo os beneficiadores "as mãos de quem tiver quebrando a castanha fica toda preta, e essa sujeira preta é muito difícil de retirar".

A combustão gerada a partir da queima da castanha libera o Líquido de Castanha de Caju (LCC), um óleo bruto, cáustico, que é bastante inflamável e libera novos gases poluentes na atmosfera. O LCC está presente no mesocarpo esponjoso na proporção aproximada de $22 \%$ do peso da castanha de caju (Figura 1).

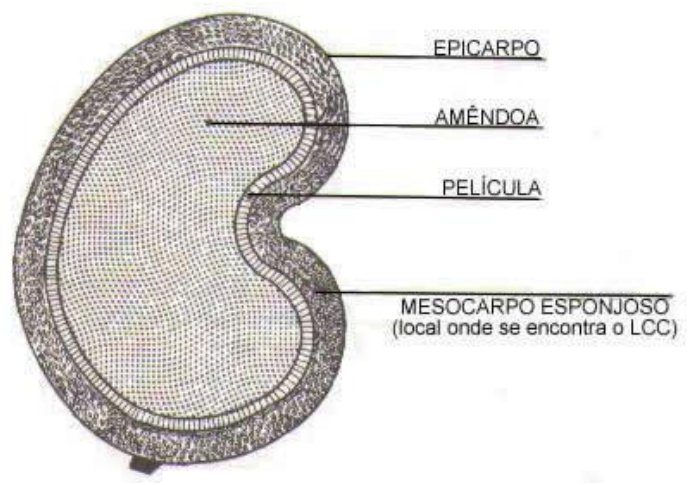

Figura 1. Desenho esquemático dos tecidos da castanha de caju.

Figura original (http://www.mecol.com.br/portugues/informacajuebrasil.htm). 
A sua composição química "in natura" é formada basicamente por duas substâncias: cerca de 10\% é constituído de cardol, que é um difenol, e 90\% de ácido anacárdico. Ao ser aquecido o LCC descarboxila o ácido anacárdico, e origina um fenol monohídrico, o cardanol. A casca da castanha de caju utilizada como combustível possui em média de $10 \%$ a $11 \%$ de LCC (Phani Kumar et al. 2002).

A fumaça gerada durante a queima da castanha possui altas concentrações de MP, sendo esse MP originado tanto da própria queima da castanha, quanto da combustão completa da casca da castanha. A fumaça gerada pela atividade é inalada diariamente por grupos familiares que participam do processo de beneficiamento da castanha por um período que pode exceder 10 horas diárias.

O trabalho de beneficiamento da castanha de caju inicia-se com a queima da castanha aproximadamente às 2 horas da manhã, e na maioria dos grupos familiares a queima segue de forma contínua até às 12 horas, sendo o restante do dia utilizado para os passos finais do beneficiamento. As fases finais do processo são a retirada da última pele da castanha e o acondicionamento das amêndoas em sacos, sendo esse último passo o mais breve dos processos e onde as crianças participam ativamente. Segundo os beneficiadores, "a madrugada é o horário mais confortável para realizar a atividade, pois a baixa temperatura desse horário diminui o desconforto produzido pelas altas temperaturas atingidas durante o processo de queima da castanha".

Durante esse período (aproximadamente 10 horas), grupos familiares ficam expostos a fumaça gerada pelo processo de queima. Exceto as crianças e idosos incapazes, todos, adolescentes, adultos e parte dos idosos cumprem a mesma rotina de trabalho e conseqüentemente a mesma rotina de exposição à fumaça gerada durante a queima. O convívio com a fumaça é tão natural, que mesmo mulheres grávidas continuam o trabalho durante o período de gestação, e as crianças que não trabalham diretamente convivem e brincam no mesmo ambiente em que se desenvolve a atividade (Figura 2).

Apesar da grande importância, social e econômica, do beneficiamento da castanha de caju, a prática de produção da castanha é em grande parte desenvolvida de forma artesanal, contribuindo para a geração de poluentes ambientais. Considerando que a qualidade do ar que se respira é de fundamental importância para a saúde das pessoas, e que existem muitas famílias que utilizam a atividade de 
queima da castanha de caju como única fonte de renda em vários países e especialmente em uma significativa área do Nordeste brasileiro, o estudo desta prática, da determinação dos poluentes, e da qualidade da saúde advinda da atividade se torna urgente.

Os indicativos de danos à saúde gerados pela atividade demandam estudos toxicológicos amplos, fazendo-se necessária à identificação tanto dos principais agentes químicos envolvidos no processo, bem como os efeitos das misturas in situ em organismos monitores expostos como plantas e o próprio homem já exposto durante o processamento da castanha. As possíveis genotoxinas oriundas da queima de matéria orgânica podem causar graves conseqüências nos seres vivos. 

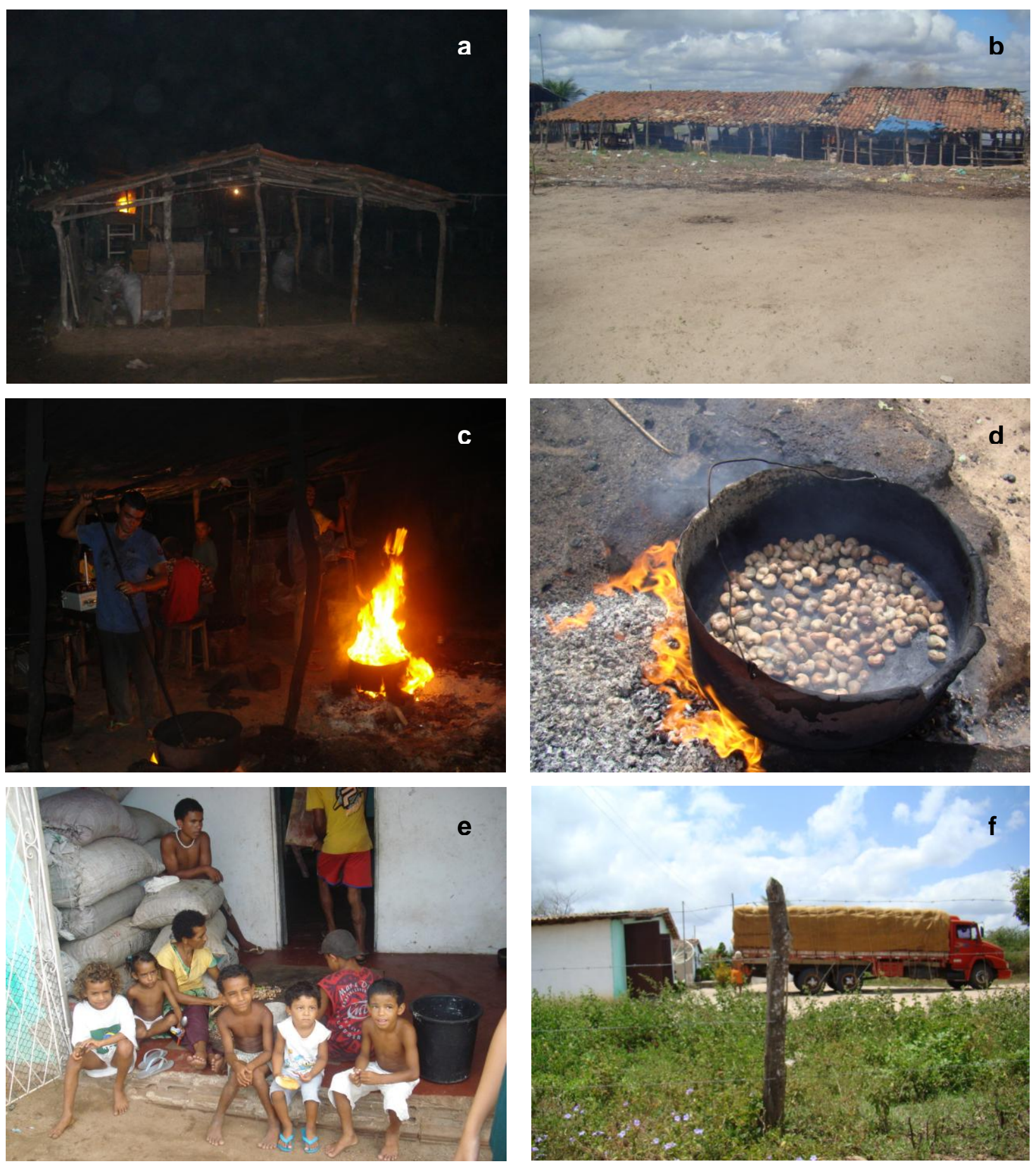

Figura 2. Processo de beneficiamento da castanha de caju amplamente desenvolvido na comunidade do Amarelão. a e b - Palhoças utilizadas como local de beneficiamento da castanha de caju; c - Grupo familiar envolvido com a atividade; $\mathbf{d}$ Panela utilizada para o cozimento da castanha de caju, chamado de "caco" pelos beneficiadores; e - Etapa final do beneficiamento (retirada da última pele da amêndoa). f - Caminhão usado para transportar a castanha beneficiada na comunidade do Amarelão para centros de comercialização. 


\subsection{Indicadores de exposição a poluentes ambientais}

Em geral, a exposição a poluentes atmosféricos como $\circ \mathrm{O}_{3}, \mathrm{NO}_{2}$ e material particulado estão associados ao aumento no número de entradas em hospitais devido a doenças cardiovasculares, respiratórias e mortalidade em diversas cidades do mundo (WHO 2003; Kampa \& Castanas 2008). No Brasil, os limites de poluentes atmosféricos permitidos estão apresentados na resolução CONAMA/N N. 003 de 28 de junho de 1990 (CONAMA 003/1990). Nessa resolução são determinados como padrões primários e secundários da qualidade do ar: a) Padrões Primários de "Qualidade do ar" são as concentrações de poluentes que, ultrapassadas, poderão afetar a saúde da população; b) Padrões Secundários de "Qualidade do ar" são as concentrações de poluentes abaixo das quais se prevê o mínimo efeito adverso sobre o bem-estar da população, assim como o mínimo dano à fauna, à flora, aos materiais e ao meio ambiente em geral.

A identificação dos poluentes pode auxiliar no entendimento dos efeitos da exposição, podendo ser determinado inclusive qual a fonte poluidora. Desse modo, as análises da presença de poluentes ambientais podem auxiliar aos gestores nas tomadas de decisões que visem minimizar os efeitos da exposição aos poluentes, permitindo melhoria na qualidade de vida das pessoas.

\subsubsection{Ozônio $\left(\mathrm{O}_{3}\right)$}

$\mathrm{O}_{3}$ tem importante papel na estratosfera protegendo os organismos da radiação ultravioleta. Contudo, na troposfera, $\mathrm{o}_{3}$ é uma molécula reativa que tem impactos negativos na saúde humana, clima e vegetação (Alvim-Ferraz et al. 2006; Pires et al. 2008).

$\mathrm{O}_{3}$ e o $\mathrm{NO} 2\left(\mathrm{OX}=\mathrm{O}_{3}+\mathrm{NO}_{2}\right)$ são importantes oxidantes fotoquímicos presentes na troposfera. "Oxidantes fotoquímicos" é a denominação que se dá à mistura de poluentes secundários formados pelas reações entre os óxidos de nitrogênio $\left(\mathrm{NOx}=\mathrm{NO}+\mathrm{NO}_{2}\right)$ e compostos orgânicos voláteis, na presença de luz solar, sendo o NOx liberado na queima incompleta e evaporação de biomassa, combustíveis e solventes (CETESB). O ozônio na troposfera é formado principalmente pela reação fotoquímica " $\mathrm{NO}_{2}+\mathrm{hv}+\left(\mathrm{O}_{2}\right) \rightarrow \mathrm{NO}+\mathrm{O}_{3}$ " ( $\mathrm{hv}-$ fóton de energia radiante) (Jenkin 2004a, 2004b). Além do $\mathrm{O}_{3}$ oriundo da oxidação 
fotoquímica, as concentrações de $\mathrm{O}_{3}$ podem também se elevar devido as alterações verticais envolvendo a chegada de $\mathrm{O}_{3}$ da estratosfera para a troposfera, e pelo transporte horizontal devido a ação dos ventos que levam $\circ \mathrm{O}_{3}$ do local onde é produzido para locais distantes (Dueñas et al. 2002; Pires et al. 2008). Como resultado da origem principalmente fotoquímica, $\quad \mathrm{O}_{3}$ apresenta forte variação sazonal e diurna, com altas concentrações no verão e no final da tarde. A correlação com outros poluentes variam com a estação do ano e com o local analisado (WHO 2003).

Nas regiões próximas a fontes de emissões de NOx, onde existem abundancia de $\mathrm{NO}, \mathrm{o}_{3}$ é removido e como resultado a concentração é freqüentemente baixa nos centros urbanos, e maiores nas regiões suburbanas e áreas rurais adjacentes. Altas concentrações de ozônio estão tanto relacionadas com o aumento da permeabilidade pulmonar, como pode causar hiper-responsividade nos brônquios. Além disso, a exposição combinada de ozônio e MP possuem uma ação sinérgica e negativa para os organismos expostos (WHO 2003).

No Brasil, a resolução CONAMA delimita a concentração média máxima de $\mathrm{O}_{3}$ em $160 \mu \mathrm{g} / \mathrm{m}^{3}$ de ar durante 1 (uma) hora, não devendo esse limite ser excedido mais de uma vez por ano (Padrão Primário e Secundário) (CONAMA 003/1990). A Organização Mundial de Saúde (OMS) determina o valor de $100 \mu \mathrm{g} / \mathrm{m}^{3}$ de $\mathrm{O}_{3}$, como medida máxima de exposição em 8 horas diárias. Para a OMS, exposições por mais de 6 horas diárias a concentrações iguais ou superiores a $160 \mu \mathrm{g} / \mathrm{m}^{3}$ de $\mathrm{O}_{3}$ estão associadas com alterações fisiológicas e inflamação nos pulmões de jovens adultos, efeitos adversos em crianças, e aumento de $3 \%-5 \%$ na mortalidade do número de indivíduos que morrem devido à exposição a altas concentrações de $\mathrm{O}_{3}$. A presença de níveis a cima de $240 \mu \mathrm{g} / \mathrm{m}^{3}$ implica em efeitos significativos nas populações (WHO 2005a).

\subsubsection{Dióxido de Nitrogênio (NO2)}

A emissão antropogênica de NOx resulta de processos de combustão, incluindo a queima de biomassa e a combustão de combustíveis fósseis no motor de veículos, fontes residenciais e industriais. Eventos naturais como processos biológicos anaeróbicos no solo e na água, atividade vulcânica e destruição fotoquímica de componentes de nitrogênio na atmosfera, também contribuem para a 
produção de NOx ((USEPA) 1998; Pires et al. 2008). O NOx tem diversos efeitos negativos sendo relacionado inclusive com a formação de chuvas ácidas e na deterioração da qualidade da água.

$\mathrm{O} \mathrm{NO}_{2}$ é de maior interesse que o NOx do ponto de vista da saúde humana. Pessoas que sofrem de doenças respiratórias como a asma, são muito sensíveis ao $\mathrm{NO}_{2}$ em altas concentrações (European-Commission 1997; WHO 2003). Altos níveis de $\mathrm{NO}_{2}$ outdoor em áreas residenciais contribuem para o aumento de doenças respiratórias e cardiovasculares, e consequentemente com a mortalidade das pessoas (Chaloulakou et al. 2008; Latza et al. 2009).

Comumente $\mathrm{O}$ monitoramento de $\mathrm{NO}_{2}$ ocorre em centros urbanos, sendo dificilmente realizado em áreas rurais. $\mathrm{O} \mathrm{NO}_{2}$ é um dos mais comuns poluentes do ar, tanto outdoor, quanto indoor (Lai et al. 2006). As principais fontes de $\mathrm{NO}_{2}$ outdoor são fontes de combustão móveis ou estacionárias (Lewné et al. 2004; Kampa \& Castanas 2008), e as fontes indoor são gás de cozinha, forno a lenha, lareiras e o fumo de tabaco (WHO 2005a). $\mathrm{O} \mathrm{NO}_{2}$ é formado da combinação de nitrogênio e oxigênio durante o processo de combustão, sendo principalmente um poluente secundário, onde o $\mathrm{NO}$ emitido é transformado em $\mathrm{NO}_{2}$ na atmosfera a partir de processos fotoquímicos ( $\mathrm{NO}+\mathrm{O}_{3} \rightarrow \mathrm{NO}_{2}+\mathrm{O}_{2}$ ) (Jenkin 2004a; Chaloulakou et al. 2008). No entanto, $\mathrm{O} \mathrm{NO}_{2}$ também pode ser produzido como um poluente primário (Carslaw 2005). Em conjunto, $\mathrm{O} \mathrm{NO}_{2}$ produzido pode interagir com outros componentes originando novos poluentes secundários pela oxidação fotoquímica (Kornartit et al. In press).

As concentrações de NO2 permitidas na legislação brasileira são de $100 \mu \mathrm{g} / \mathrm{m}^{3}$ de concentração média anual (Padrão Primário e Secundário), $320 \mu \mathrm{g} / \mathrm{m}^{3} \mathrm{em}$ uma hora (Padrão Primário) e $190 \mu \mathrm{g} / \mathrm{m}^{3}$ em uma hora (Padrão Secundário) (CONAMA 003/1990). Para a OMS a concentração média anual não pode exceder $40 \mu \mathrm{g} / \mathrm{m}^{3} \mathrm{e}$ $200 \mu \mathrm{g} / \mathrm{m}^{3}$ em uma hora (WHO 2005a). 


\subsection{Identificação e composição do Material Particulado}

O material particulado é um conjunto de poluentes constituídos de poeiras, fumaças e todo tipo de material sólido e líquido que se mantém suspenso na atmosfera devido ao seu pequeno tamanho aerodinâmico. O MP representa uma complexa mistura de substâncias orgânicas e inorgânicas, onde as partículas do aerossol atmosférico podem variar quanto ao tamanho em mais do que quatro ordens de grandeza, desde pequenos agrupamentos contendo algumas moléculas em gotículas até partículas de poeira com tamanho de até dezenas de microns. O tamanho das partículas está diretamente associado ao seu potencial para causar problemas à saúde, sendo que, quanto menores, maiores os efeitos provocados (WHO 2005b). A composição química do MP é bastante variada, e depende principalmente da fonte de emissão. De forma geral o MP é classificado de acordo com o seu diâmetro aerodinâmico em fração grossa (MP 10) ou fração fina (MP 2,5), também chamado de partículas inaláveis ou partículas respiráveis, respectivamente. É possível ainda, classificar as menores partículas em fração ultrafina $(<0,1 \mu \mathrm{m})$, as quais constituem uma forma secundária do aerossol, formadas no processo de conversão gás-partícula. As partículas ultrafinas têm um tempo de residência na atmosfera mais curto, uma vez que se agregam formando partículas finas.O diâmetro aerodinâmico como classificação é conveniente porque está associado com: a) O transporte e a remoção do particulado do ar; b) A deposição no sistema respiratório; c) A composição química e a fonte do particulado.

A fração particulada maior que MP 2,5, quando inalada, não ultrapassa as vias respiratórias superiores, sendo retida pelo mecanismo mucociliar (fração grossa). A fração menor que MP 2,5 (fração respirável) pode atingir as vias aéreas inferiores, chegando aos alvéolos pulmonares, onde pode exercer seu potencial tóxico sobre as células alveolares, como macrófagos, neutrófilos e células epiteliais (Donaldson et al. 2001; Cormier et al. 2006) (Figura 3).

Em geral, as partículas maiores se deslocam pouco no meio ambiente, tendo uma origem local. Já o particulado fino, tem maior capacidade de dispersão, podendo ser transportado por longas distâncias. A fração grossa é originada principalmente de fontes naturais a partir da quebra de partículas maiores. Estas partículas são formadas pela ação dos ventos na poeira, no solo, pelo tráfego de veículos, em 
regiões litorâneas pela evaporação do spray do mar, além de componentes orgânicos como estruturas de insetos, grãos de pólen e esporos de fungos e plantas. A quantidade de energia necessária para quebrar as partículas em tamanhos menores aumenta à medida que diminui o tamanho do MP.
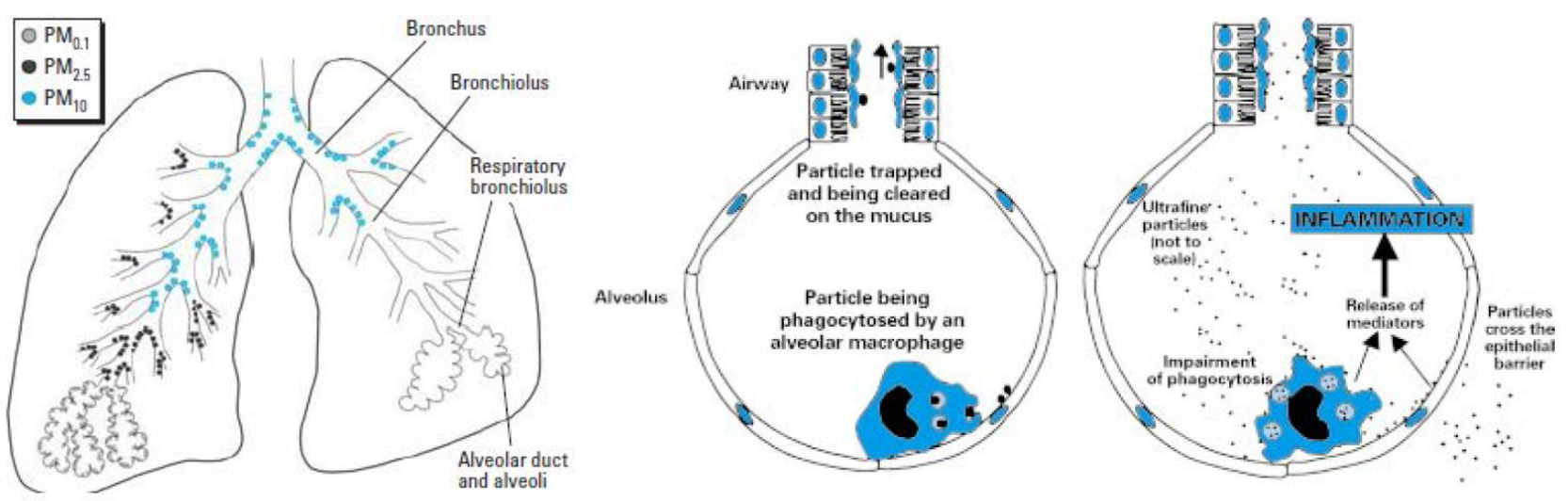

Figura 3. Distribuição do MP nas vias aéreas. $\mathrm{OMP} \geq 10 \mu \mathrm{m}$ é retido entre o nariz e a boca. MP $10 \mu \mathrm{m}$ ultrapassa a laringe e penetra na traquéia e brônquios. MP 2,5 $\mu \mathrm{m}$ chega aos alvéolos pulmonares. Figura original (Donaldson et al. 2001; Cormier et al. 2006).

A fração particulada fina (MP 2,5), na maioria dos casos, é formada a partir de atividades antropogênicas, como a combustão de combustíveis fósseis e processos industriais. O MP 2,5 contém partículas primárias (produzidas diretamente pelas fontes emissoras) e secundárias (principalmente sulfatos e nitratos), geradas pelo processo de conversão gás-partícula a partir de óxidos de enxofre e óxidos de nitrogênio (Makkonen et al. In press).

Para se realizar medições da concentração do MP disperso levando-se em consideração tanto o tamanho do MP quanto a composição química da mistura, pode ser realizadas análises com auxílio de amostradores passivos ou amostradores ativos. Os amostradores passivos coletam a substância da atmosfera de acordo com a capacidade de difusão da amostra e sua reação com o meio absorvente (ou adsorvente) do amostrador. Já os amostradores ativos utilizam uma bomba de aspiração acoplada ao equipamento, permitindo a aquisição da amostra de forma ativa, podendo ainda, o material coletado ser acumulado em um filtro (McMurry 2000). 


\subsection{Composição Elementar do Material Particulado}

A concentração de Material Particulado é uma medida importante, contudo é inespecífica, pois indica a presença de uma mistura de poluentes presentes no ar. Análises da concentração de MP 10 ou MP 2,5 além de ser uma avaliação quantitativa, indicam de acordo com o tamanho aerodinâmico do MP, até que ponto o poluente pode atingir as vias aéreas no homem.

O material particulado é uma mistura de muitas substâncias que diferem quanto à solubilidade, persistência na atmosfera e no tecido humano, reatividade, toxicidade e carcinogenicidade. Além das características físicas como o número de partículas e tamanho, a natureza química do material particulado pode representar uma importante ferramenta no entendimento dos efeitos dos agentes poluidores (WHO 2003; Götschi et al. 2005).

Outro interesse na análise qualitativa do material particulado é a possibilidade de identificar as fontes de emissão de poluentes, com o objetivo de serem realizadas melhores políticas de controle da emissão dos elementos poluidores. Contudo, o material disperso na atmosfera não é necessariamente fonte-específica, e a composição pode variar significativamente no tempo e espaço devido a variações nas fontes de emissões, condições meteorológicas, processos físicos, e reações químicas (Götschi et al. 2005).

Desse modo, a identificação elementar pode auxiliar no entendimento de qual ou quais são os principais elementos que estão interagindo de forma negativa no meio ambiente. A técnica analítica nuclear de fluorescência de raios $X(X R F)$ tem sido utilizada para a avaliação quali-quantitativa da composição química em vários tipos de amostras. Esta técnica, por permitir a análise de vários elementos simultaneamente, de modo rápido e a baixo custo, tem um elevado potencial de aplicação em várias áreas, onde há necessidade de identificar as concentrações de elementos essenciais e tóxicos.

\subsection{Genotoxicidade e monitoramento biológico}

Em geral, os poluentes não são detectados se não causarem efeitos imediatos nos organismos expostos. No entanto, o efeito crônico da exposição contínua a 
determinadas substâncias pode reduzir a sobrevivência dos animais em longo prazo, acarretando diversos prejuízos e desordens antes de se tornarem clinicamente visíveis (White \& Rasmussen 1998).

Como conseqüência dos efeitos de genotoxinas nos organismos pode-se incluir perda de gametas, diminuição do sucesso reprodutivo, desenvolvimento anormal, câncer e mutações letais L (Mortelmans \& Zeiger 2000; Diekmann et al. 2004; Malling 2004).

Em sentido amplo, genotoxicidade corresponde a todos os tipos de danos no DNA. Agentes que causam lesão no DNA são designados genotóxicos. Efeitos genotóxicos incluem quebra no DNA, síntese não programada de DNA, trocas de cromátides irmãs (SCE), entre outros (Dearfield et al. 2002). Devido à ampla variedade de eventos genéticos possíveis, não há atualmente nenhum teste para detectar o espectro completo dos diferentes "endpoints" abrangidos pela genotoxicidade induzida. No entanto, baterias de testes têm sido desenvolvidas para avaliar efeitos nos principais "endpoints" associados a danos genéticos com doenças humanas: mutações gênicas (substituições de base, deleções e inserções) e mutações cromossômicas (clastogenicidade - aberrações cromossômicas estruturais; e aneuploidia - aberrações cromossômicas numéricas) (Dearfield et al. 2002).

Mutagenicidade é definida como uma alteração na seqüência nucleotídica a qual permanece após um ciclo de replicação celular. Um evento mutagênico pode ser descrito como uma mudança herdável, resultante de uma mutação na linhagem germinal e/ou mutações somáticas que levam ao câncer ou a outros processos degenerativos crônicos como o envelhecimento e doenças cardíacas coronarianas (Dearfield et al. 2002).

Entre os poluentes ambientais com capacidade mutagênicas, a fração fina do material particulado (MP 2,5) tem apresentado grande efeito genotóxico nos organismos (WHO 2003). Atualmente, várias técnicas têm sido utilizadas para análises da qualidade do ar. Entre essas, as análises que incluem a avaliação de compostos genotóxicos tem tomado destaque. Análises de genotoxicidade incluem métodos que permitem avaliar se diferentes agentes químicos e físicos, individualmente ou associados, possuem capacidade de interferir na estrutura da molécula de DNA. Os resultados de genotoxicidade possuem relação com doenças 
graves, como o câncer, doenças cardiovasculares, doenças obstrutivas pulmonares e neurodegenerativas (Pope et al. 2002; Mariani et al. 2009; Yang \& Omaye 2009).

Entre os testes para análises de genotoxicidade, os testes de micronúcleo em plantas e em animais têm demonstrado eficiência para esse tipo de avaliação. Com relação aos poluentes ambientais, as plantas possuem a vantagem de serem facilmente levadas para o local teste, e em apresentando condições locais favoráveis de cultivo, podem ser expostas por longos períodos ao meio ambiente, atuando como um importante biomonitor. Outra forma de se utilizar as plantas nas análises de genotoxicidade é em condições de laboratório, onde o agente químico teste pode ser um agente isolado ou uma mistura, tanto purificado em laboratório ou coletado no meio ambiente, o qual, ao ser colocado em contato com a planta pode vir a apresentar o marcador biológico.

Com relação aos animais, várias espécies ou linhagens celulares de determinadas espécies são usadas na detecção de marcadores biológicos de exposição a poluentes ambientais (Barbosa et al. In press; Delgado-Rodriguez et al. 1995; Kevekordes et al. 1996; Angerer et al. 2007). Os vertebrados possuem uma interação dinâmica com o meio ambiente, crucial para a sobrevivência, onde continuamente sofrem ajustes fisiológicos (resposta adaptacional) de acordo com um ambiente sempre em mudança. Para isso, esses organismos possuem um repertório aparentemente infinito de respostas fisiológicas, endocrinológicas, e imunológicas que permitem verdadeiramente, lidar com distúrbios físicos, químicos e biológicos. Em geral, o uso de diferentes espécies promove uma possibilidade de extrapolação dos resultados para outras, inclusive para o homem. Para utilizar o homem como espécie biomonitora, é necessário que o mesmo já conviva naquele ambiente de forma natural, não sendo ética a exposição voluntária do homem a agentes potencialmente lesivos a saúde dos participantes. Além disso, quando existe a possibilidade de trabalhar com humanos é importante o uso de técnicas paralelas, para que a comparação com o teste em humanos auxilie no fortalecimento de uso de outras espécies, que não o homem, objetivando a facilitação de estudos nos mais diversos ambientes. 


\subsection{Testes utilizados na detecção de genotoxicidade}

Ensaios que detectam compostos genotóxicos permitem identificar substâncias com risco potencial a saúde humana, sejam químicos, naturais, sintéticos, fitoterápicos ou amostras ambientais (Ribeiro et al. 2003; Chen \& White 2004; Ohe et al. 2004). Ensaios com organismos para a medição de várias respostas biológicas tais como, fragmentação do DNA e formação de micronúcleos, evidenciam uma alternativa para a avaliação da qualidade do ar.

Danos no genoma representam provavelmente a causa mais importante no desenvolvimento de doenças degenerativas. É bem estabelecido que esses danos podem ser produzidos por exposições a genotoxinas presentes no meio ambiente, a procedimentos médicos (tratamentos com o uso de radiação e quimioterápicos), a deficiência nutricional em micronutrientes, a fatores relacionados ao estilo de vida (consumo de álcool, cigarros, drogas e estresse), e fatores genéticos como defeitos herdados no metabolismo e/ou reparo no DNA (Fenech et al. 2007; Holland et al. 2008).

Atualmente, diversos organismos têm sido usados na avaliação da genotoxicidade de diferentes amostras ambientais. Os mais comuns são as bactérias, utilizando o teste de Ames pelo método direto e com microsuspensão, e o teste de Kado, com as diferentes linhagens de Salmonella typhimurium (Umbuzeiro et al. 2004; Wu 2005; Umbuzeiro et al. 2006a; Umbuzeiro et al. 2006b); plantas superiores (Allium cepa e Tradescantia (Guimarães et al. 2000; Rank 2003; Ferreira et al. 2007; Misík et al. 2007; Savóia et al. 2009); moluscos (Mytilus sp., Limnoperna fortunei) (Rank \& Jensen 2003; Akcha et al. 2004; Villela et al. 2006); peixes (Oreochromis niloticus, Astyanax bimaculatus, Hoplias malabaricus e Anguilla anguilla) (Molina et al. 2005; Ahmad et al. 2006; Silmara de Moraes et al. 2006), e até mesmo o homem (Angerer et al. 2007).

Com toda essa gama de diferentes organismos, a escolha da espécie biomonitora deve ser baseada em critérios como: ocorrência natural da espécie na área estudada, sensibilidade da espécie aos diferentes químicos presentes naquele ambiente, facilidade de manutenção em laboratório e logística adequada para a realização do teste escolhido. Embora existam diferenças nas espécies quanto ao 
metabolismo, reparo de DNA, e outros processos fisiológicos, a universalidade do DNA permite certa lógica para o uso de vários sistemas testes para predizer a genotoxicidade intrínseca de diferentes compostos testados.

Entre os vários testes marcadores de mutagenicidade, o teste de micronúcleo em $T$. pallida e em mucosa oral humana tem apresentado sensibilidade a diferentes compostos. Esses testes apresentam tanto viabilidade técnica, quanto econômica com relação à execução.

\subsubsection{Teste de Micronúcleo}

O estudo de danos no DNA em nível cromossômico é uma parte essencial da genética toxicológica devido às mutações cromossômicas representarem um importante evento na carcinogênese (Fenech 2000). O micronúcleo é considerado uma das ferramentas indispensáveis como biomarcador de exposição a agentes carcinogênicos (Au 2007), representando o ensaio in vivo mais utilizado para a detecção de agentes clastogênicos (que quebram o cromossomo) e aneugênicos (que induzem aneuploidia ou segregação cromossômica anormal) (MacGregor et al. 1987; Hayashi et al. 1994; Buschini et al. 2004; Bolognesi et al. 2006).

O micronúcleo é uma pequena massa nuclear delimitada por membrana e separada do núcleo principal, sendo formado durante a telófase da mitose ou meiose. Os micronúcleos aparecem apenas em células que completaram a divisão nuclear, e são originados de fragmentos de cromossomos ou cromossomos inteiros que se atrasaram durante a migração cromossômica ocorrida na anáfase (Holland et al. 2008). Desse modo, os micronúcleos representam perda da cromatina em conseqüência do dano cromossômico estrutural ou dano no aparelho mitótico (AlSabti \& Metcalfe 1995). Os resultados positivos do teste de micronúcleo fornecem fortes evidências de mutagenicidade sistêmica do efeito da substância química avaliada.

\subsubsection{Micronúcleo em Tétrades de Tradescantia pallida}

O uso de bioindicadores vegetais para avaliar mutagenicidade representa uma alternativa eficiente e de baixo custo para analisar o potencial mutagênico de agentes contaminantes ambientais. Desse modo, o teste de micronúcleos em T. pallida (Trad - 
MCN) tem sido amplamente utilizado devido a sua alta sensibilidade a compostos genotóxicos. Este bioensaio mostrou-se sensível a poluentes atmosféricos in situ (Batalha et al. 1999; Guimarães et al. 2000; Carreras et al. 2006; Prajapati \& Tripathi 2008; Carreras et al. 2009; Meireles et al. 2009; Savóia et al. 2009), a poluentes atmosféricos em laboratório (Carvalho-Oliveira et al. 2005b; de Souza Lima et al. 2009), lodo de esgoto tratado (Mielli et al. 2009), produtos químicos (Alves et al. 2008) e depósitos radioativos (Cristina dos Santos Leal et al. 2008). O bioensaio de micronúcleo em tétrades de Tradescantia (Trad-MCN) é um dos testes mais utilizados em estudos de genética toxicológica. Esse teste pode ser realizado com as inflorescências da T. pallida ou dos clones de Tradescantia, e entre os clones, os principais são o BNL-4430 desenvolvido no Brookhaven National Laboratory, Estados Unidos e o KU-20 selecionado na Universidade de Kyoto, Japão. O teste baseia-se na contagem de micronúcleos (Figura 17), os quais são visualizados na fase de tétrade jovem, final do processo de meiose. A freqüência de micronúcleos tem sido utilizada para avaliar o grau de dano mutagênico aos quais as células germinativas (tétrades) desta planta são expostas, indicando a atividade mutagênica da substância em exposição (Ma 1981).

\subsubsection{Micronúcleo em mucosa oral humana}

As avaliações de mutagenicidade em humanos permitem a identificação direta do efeito do poluente nas pessoas. Em humanos, a presença de micronúcleos pode ser facilmente analisada em eritrócitos jovens, linfócitos, e em células esfoliadas epiteliais da cavidade oral, uroepitelial e nasal para obtenção da medida das mutações genômicas. As células esfoliadas são originadas da rápida divisão celular do tecido epitelial e o ensaio com essas células é realizado com os indivíduos in vivo, eliminando a necessidade de uma divisão celular ex vivo em cultura de células (Holland et al. 2008).

O ensaio de micronúcleos em células da mucosa oral apresenta-se como uma técnica minimamente invasiva, especialmente em comparação a obtenção de amostras do sangue (linfócitos e eritrócitos) ou de tecido de biópsia, e por isso apresenta-se como um excelente biomarcador para análises em humanos (Holland et al. 2008). 
O teste de micronúcleo em mucosa oral humana foi primeiramente proposto por Stich et al. 1983 (Stich et al. 1983) e atualmente tem sido utilizado para monitorar populações humanas expostas a uma variedade de agentes físicos e químicos com potencial mutagênico e carcinogênico (Holland et al. 2008). A mucosa oral é a primeira barreira na rota de inalação ou ingestão, sendo capaz de metabolizar imediatamente componentes, transformando-os em produtos reativos, representando um tecido alvo para os primeiros eventos de genotoxicidade no homem. O epitélio oral é composto de três camadas, mais a lâmina própria (tecido conjuntivo). São elas: camada superficial de células esfoliadas, o estrato espinhoso intermediário e o estrato basal (Figura 4).

(A)

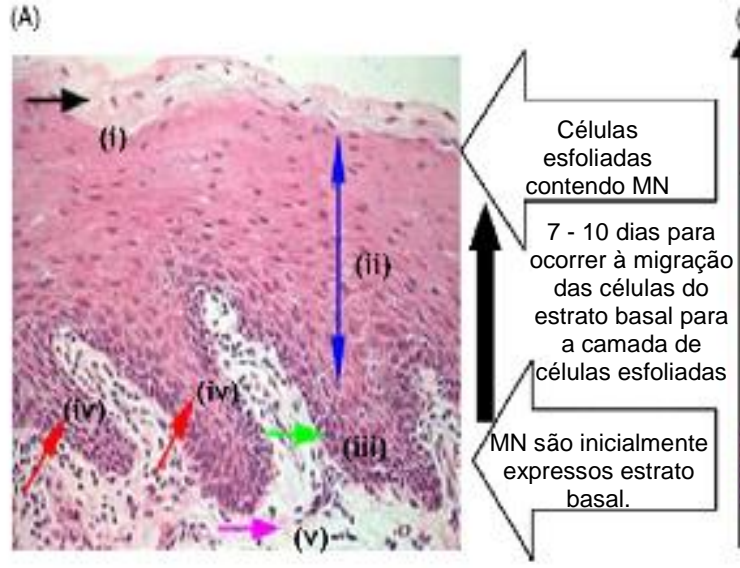

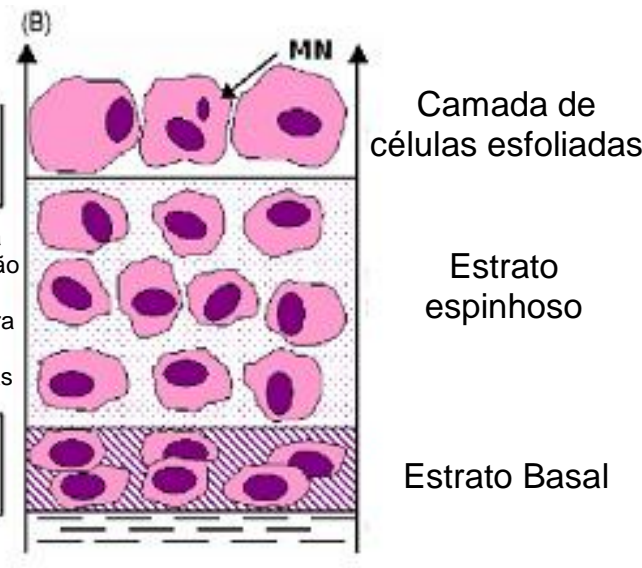

Figura 4. Estrutura e diferenciação do epitélio oral. A - Fotomicrografia do epitélio de mucosa oral humana mostrando as diferentes camadas de células do epitélio e o tecido conjuntivo subjacente. O epitélio oral é classificado como epitélio escamoso estratificado. (i) Camada de células esfoliada; (ii) Estrato espinhoso; (iii) Estrato basal; (iv) "Rete pegs" - extensões epiteliais que se projetam no tecido conjuntivo; (v) Lâmina própria - tecido conjuntivo. B - Desenho esquemático ilustrando as camadas do epitélio da mucosa oral: Células esfoliadas, estrato espinhoso e estrato basal.

Figura original (http://www.eastman.ucl.ac.uk/cal/ulcerspath/healthy.htm). Retirada de Holland et al. 2008, com adaptações. 
O epitélio oral é mantido por continua renovação celular, onde novas células produzidas na lâmina basal por mitose migram para a superfície, repondo as células perdidas. A lâmina basal contém as células que podem apresentar o biomarcador (MN) durante a divisão nuclear. As células filhas, as quais podem ou não conter micronúcleos, se diferenciam em estrato espinhoso e em seguida em células esfoliadas. 


\section{OBJETIVO GERAL}

Avaliar os constituintes e o potencial mutagênico do MP associado ao beneficiamento artesanal da castanha de caju no município de João Câmara - RN.

\subsection{Objetivos específicos}

a) Quantificar a concentração de material particulado e de Black Carbon nos locais de queima de castanha de caju com o uso de amostradores ativos.

b) Determinar a composição elementar do material particulado acumulado em filtros de policarbonato com auxílio da técnica de fluorescência de raio $\mathrm{X}$.

c) Identificar a concentração de $\mathrm{NO}_{2}$ e $\mathrm{O}_{3}$ nos pontos testes com amostradores passivos.

d) Avaliar o potencial mutagênico da atividade do beneficiamento da castanha de caju utilizando o teste de micronúcleos em tétrades de $T$. pallida expostas aos poluentes produzidos pela queima da castanha.

e) Avaliar o potencial mutagênico da atividade em trabalhadores que beneficiam a castanha de caju a partir da análise de micronúcleos em células esfoliadas de mucosa oral. 


\section{MATERIAL E MÉTODOS}

\section{1. Área de Estudo}

Para avaliar a quantidade de MP produzido durante a queima da castanha de caju, assim como os efeitos mutagênicos da atividade, três locais distintos foram definidos como pontos testes (Figura 5): Ponto 1. Comunidade do Amarelão, situada no perímetro rural do município de João Câmara-RN (05³0'51.81"S; 3554'17.13"O), local onde ocorre a queima da castanha de caju; Ponto 2. Fazenda Santa Luzia (05³3'6.72"S; 3546'10.75"O), situada próxima à região de queima da castanha de caju, portanto com as mesma condições ambientais, porém sem a influência da atividade; Ponto 3. Universidade Federal do Rio Grande do Norte (UFRN), zona urbana de Natal-RN (0550'28.78"S; 35'12'6.85"O). Os pontos 1 e 2 não sofrem influência de emissões veiculares ou poluentes industriais.

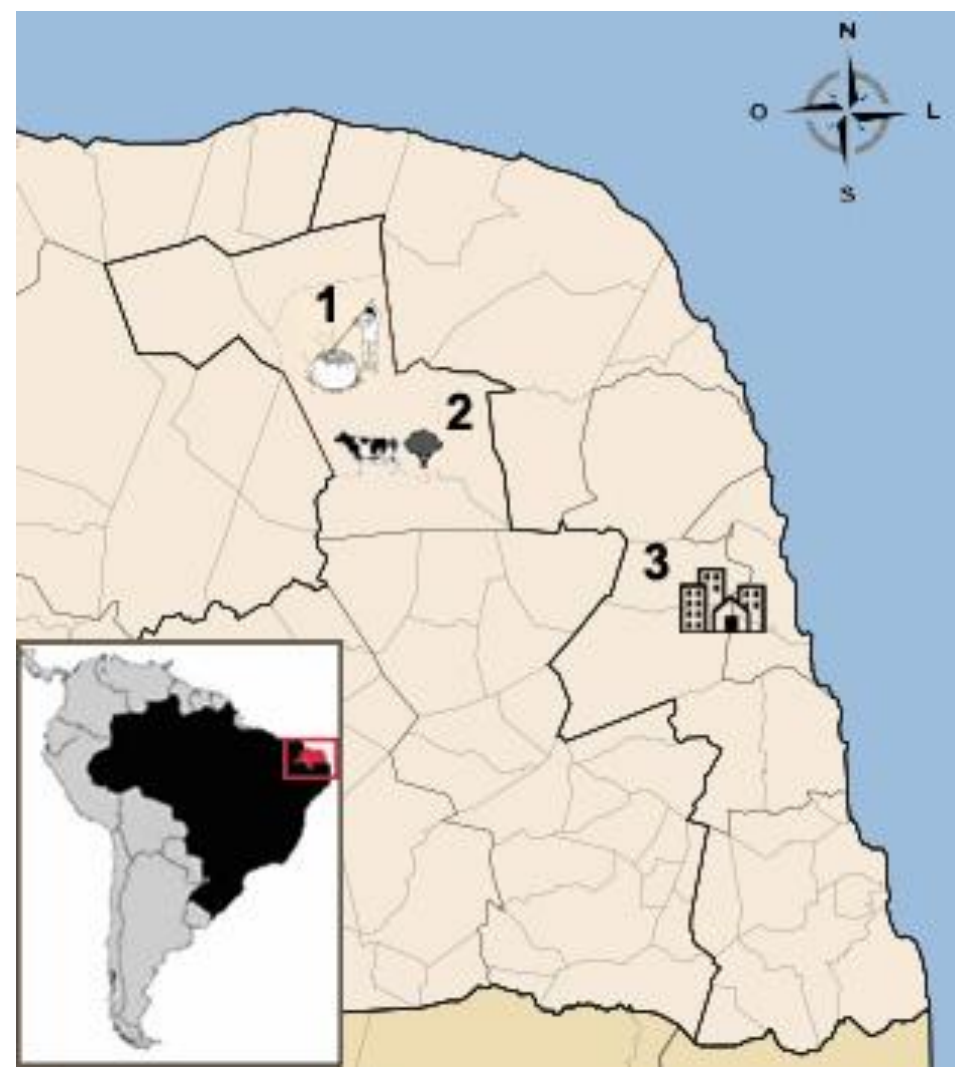

Figura 5. Mapa da área de estudo. O número "1" indica o local correspondente à comunidade do Amarelão (onde ocorre o beneficiamento da castanha de caju); o número "2" indica a localização da Fazenda Sta. Luzia; o número 3 corresponde a cidade de Natal, onde está localizada a UFRN. O sentido predominante do vento nos três pontos é Sudeste (SE) (Anexo II). 


\subsubsection{Cidade de João Câmara (Ponto 1 e 2)}

O município de João Câmara situa-se na mesorregião Agreste Potiguar e na microrregião Baixa Verde, limitando-se com os municípios de Parazinho, Touros, Pureza, Poço Branco, Bento Fernandes, Jardim de Angicos, Jandaíra e Pedra Preta, abrangendo uma área de $795 \mathrm{~km}^{2}$. A sede do município tem uma altitude média de 160 m e apresenta coordenadas $05^{\circ} 32^{\prime} 16,8^{\prime \prime}$ de latitude sul e $35^{\circ} 49^{\prime} 12,0^{\prime \prime}$ de longitude oeste, distando da capital cerca de $86 \mathrm{~km}$, sendo seu acesso, a partir de Natal, pela rodovia BR-406. O município possui um clima muito quente e semi-árido, com estação chuvosa atrasando-se para o outono. A precipitação pluviométrica anual média é de $648,6 \mathrm{~mm}$, com período chuvoso de março a agosto e seco de setembro a fevereiro do ano seguinte. A temperatura média anual fica em torno de $24,7^{\circ} \mathrm{C}$ e a umidade relativa média anual é de $70 \%$.

A população, em 2007, foi de 30.423 habitantes (IBGE, 2007). Da população total, $64,90 \%$ são alfabetizados. O município possui 6.702 domicílios permanentes, sendo 4.724 na área urbana e 1.978 na área rural. A rede de saúde dispõe de 19 estabelecimentos de saúde, sendo 18 públicos. Dentre os estabelecimentos de saúde, apenas 2 hospitais dispõem de internação com 70 leitos. (IBGE, 2005). No ano de 2008 foram registrados apenas 22 óbitos devido à morbidade hospitalar no município de João Câmara, sendo os casos mais freqüentes atribuídos a doenças agrupadas entre endócrinas, nutricionais ou metabólicas (8 óbitos). Doenças do aparelho respiratório foram consideradas o segundo causador de mortalidade (5 óbitos), em terceiro foram as doenças do aparelho circulatório (4 óbitos) e em quarto as doenças infecciosas e parasitárias (3 óbitos). Na cidade de João Câmara, nenhum óbito foi atribuído a neoplasias. Contudo, em todo o RN apenas 8 cidades apresentam registros de óbitos por neoplasias, de modo que esses valores não indicam ausência da patologia, mas sim a concentração dos internamentos em algumas cidades pólo (DATASUS, 2008).

\subsubsection{Comunidade do Amarelão - Local onde ocorre o beneficiamento da} Castanha de Caju (Figura 6).

A comunidade do Amarelão apresenta peculiaridades históricas e sociais. Os estados do Rio Grande do Norte e do Piauí são os únicos do Nordeste brasileiro que 
não há reconhecimento oficial de grupos indígenas. No $\mathrm{RN}$, atualmente três comunidades tem reivindicado a inclusão nas políticas públicas oficiais de proteção e assistência aos seus povos. As três comunidades que reivindicam são conhecidas como comunidade dos Mendonça do Amarelão (do município de João Câmara), do Catu (que vive nos municípios de Goianinha e Canguaretama) e os Caboclos do Assu (do município de Assu). A comunidade do Amarelão é formada por mais de duas mil pessoas que se identificam como uma grande família, cuja referência identitária (Mendonça), os remete a uma origem indígena (Índios Tapuias) do início do século XIX de migrantes do Brejo da Paraíba (Bananeiras) e de aldeamentos indígenas do Rio Grande do Norte (São Gonçalo) (Guerra 2003).

O "Amarelão" está situado no Município de João Câmara e essa comunidade também compreende um assentamento denominado Santa Terezinha. Esse assentamento foi conquistado pelo povo da Comunidade do Amarelão com o apoio do Movimento dos Trabalhadores Sem Terra (MST), no entanto, a região apresenta uma terra seca e infértil (Guerra 2003). A comunidade apresenta apenas um posto de saúde, e depende diretamente do Município de João Câmara para diversas atividades. A comercialização da castanha é dada de forma desorganizada, sem a presença de cooperativas, sendo a maior parte da produção vendida para atravessadores, e uma pequena parte é vendida diretamente ao público na cidade de Natal, principalmente no período de alta estação do turismo do RN.
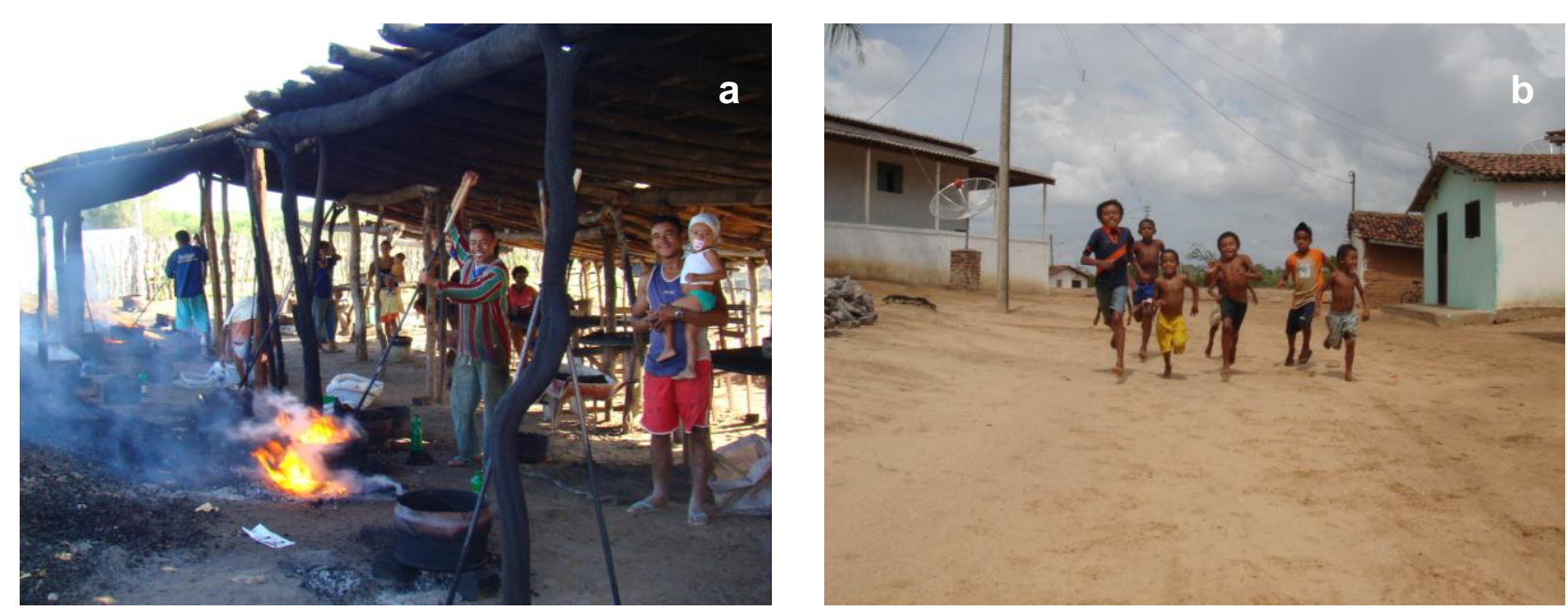

Figura 6. a - Grupos de trabalhadores da comunidade do amarelão em palhoças usadas para o beneficiamento. b - Crianças brincando entre as casas da Comunidade do Amarelão. 


\subsubsection{Fazenda Santa Luzia - Próximo ao local de beneficiamento da}

\section{Castanha de caju, mas sem influencia da atividade.}

A fazenda Santa Luzia é uma propriedade privada localizada no perímetro urbano do município de João Câmara, distando apenas 5 - $6 \mathrm{Km}$ da cidade propriamente (Figura 7). Mesmo sendo localizada no perímetro classificado no município de João Câmara como urbano, a fazenda desenvolve atividades estritamente rurais. Na fazenda há plantações de capim, milho e algumas fruteiras, além da criação de animais, como gado, galinha, ganso e pavão. O local utilizado para cultivo das plantas e coleta de Material Particulado era protegido dos animais apenas por telas, as quais permitiam a circulação livre do ar. Na fazenda não existe a influencia direta de atividades poluidoras, especialmente da queima da castanha de caju. O local está situado, aproximadamente, a $14 \mathrm{Km}$ da comunidade do Amarelão, e apresenta condições ambientais semelhantes.
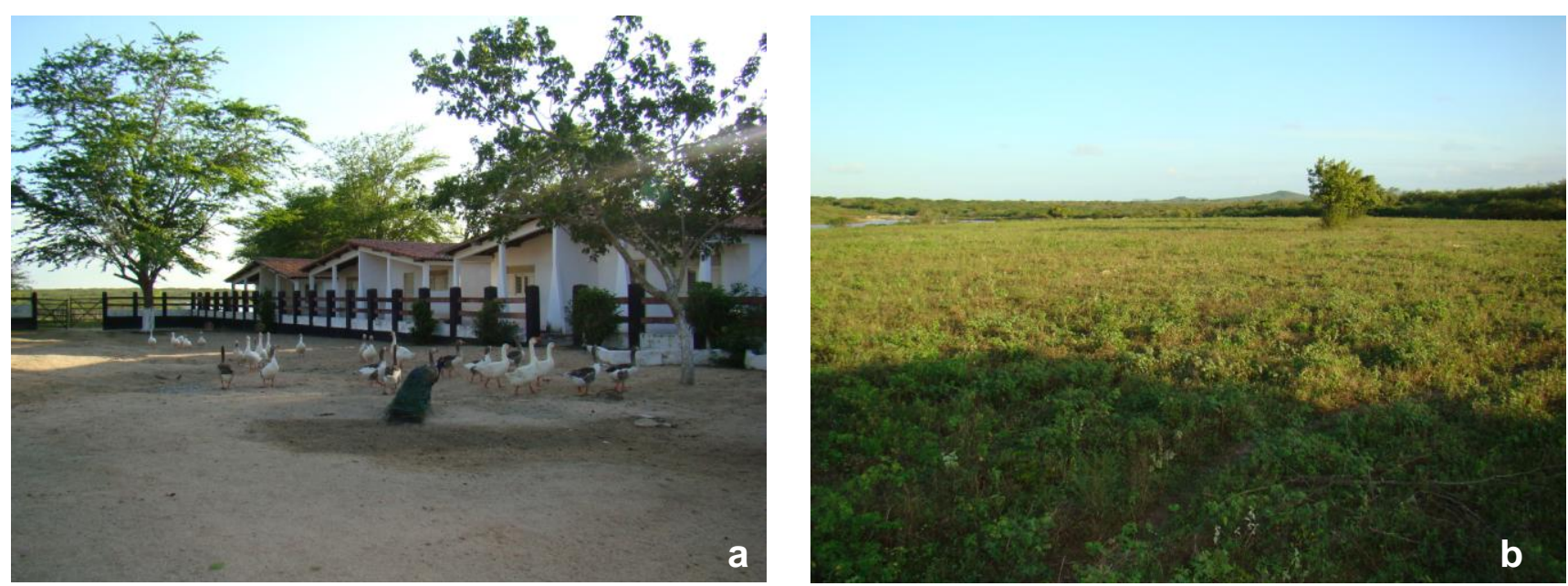

Figura 7. a e b - Fazenda Santa Luzia (Ponto 2). O local apresenta condições ambientais semelhantes à comunidade do Amarelão, mas sem influencia da atividade do beneficiamento da castanha de caju.

\subsubsection{Município de Natal - Sem influencia da queima da castanha de caju.}

A cidade de Natal é a capital do estado do Rio Grande do Norte e localiza-se na mesorregião Leste Potiguar. A cidade apresenta clima tropical úmido, com temperatura média $27,2^{\circ} \mathrm{C}$, precipitação pluviométrica anual de $2475,6 \mathrm{~mm}$ e umidade 
relativa do ar de 77,3 \% no ano de 2008 (EMPARN). Devido à proximidade com a linha do Equador, de forma geral, os dias são ensolarados, podendo chegar a $15 \mathrm{~h}$ de sol. Do mesmo modo que as demais áreas do Nordeste brasileiro, as estações do ano são pouco definidas, apresentando um clima estável, com destaque para um período sem chuvas que ocorre geralmente entre os meses de setembro a fevereiro, e outro chuvoso entre os meses de março e agosto.

A cidade possui uma população de 774.230 habitantes em uma área de 170, $298 \mathrm{Km}^{2}$ com altitude média de $30 \mathrm{~m}$ em relação ao nível do mar. As principais atividades econômicas são o turismo, o comércio, a indústria e a extração mineral (IBGE, 2007).

O Ponto 3 localiza-se no campus da Universidade Federal do Rio Grande do Norte, a qual é localizado na zona urbana da cidade de Natal. Esse ponto é influenciado pelas pessoas que transitam intensamente nesse local (estudantes e funcionários da Universidade) e pelas construções, as quais são comuns na UFRN devido à constante expansão e reforma do campus. O local dista aproximadamente $300 \mathrm{~m}$ da avenida mais próxima, a qual contorna o campus, e possui um fluxo moderado de carros. Distante $1 \mathrm{Km}$ desse ponto, é encontrado uma das avenidas de maior fluxo de veículos da cidade. Esse ponto não apresenta qualquer influencia da atividade do beneficiamento da queima da castanha de caju. 


\subsection{Indicadores de exposição a poluentes ambientais}

\subsubsection{Tubos passivos}

Amostradores passivos acumulam a amostra a partir da difusão do gás presente na atmosfera em um tubo invertido contendo uma membrana absorvente (Figura 8 e 9). O baixo custo e a flexibilidade de sistemas passivos, principalmente por não necessitarem de energia elétrica, os tornam uma alternativa atrativa para avaliações em locais de difícil acesso ou distante dos grandes centros, como comunidades rurais (Cox 2003) tal como a comunidade do Amarelão, alvo do presente estudo.

Os tubos passivos foram protegidos da chuva, do sol, e demais agentes que pudessem danificar os filtros, ou alterar os resultados, e foram expostos por um período médio de 4 dias. Os tubos foram posicionados nos três pontos testes a uma altura média de 1,60 $\mathrm{m}$, que corresponde aproximadamente à altura em que os trabalhadores que participam do processo de beneficiamento da castanha de caju respiram. Para que houvesse a padronização da técnica, antes do início do período experimental, foram realizadas três campanhas de exposição com o objetivo de aferir a técnica. Em todas as campanhas de exposição foram utilizados 6 filtros de $\mathrm{O}_{3}$ e 6 filtros de $\mathrm{NO}_{2}$. Durante cada campanha os filtros testes foram acompanhados de no mínimo 3 filtros controles. Os filtros de controle negativo ficaram no mesmo ambiente que os filtros teste, para que permanecessem em condições de temperatura semelhantes. Contudo, os filtros usados como controle permaneceram durante toda a campanha de exposição lacrados em sacos Zip Lock os quais também eram usados para o transporte dos demais filtros (controle e teste).
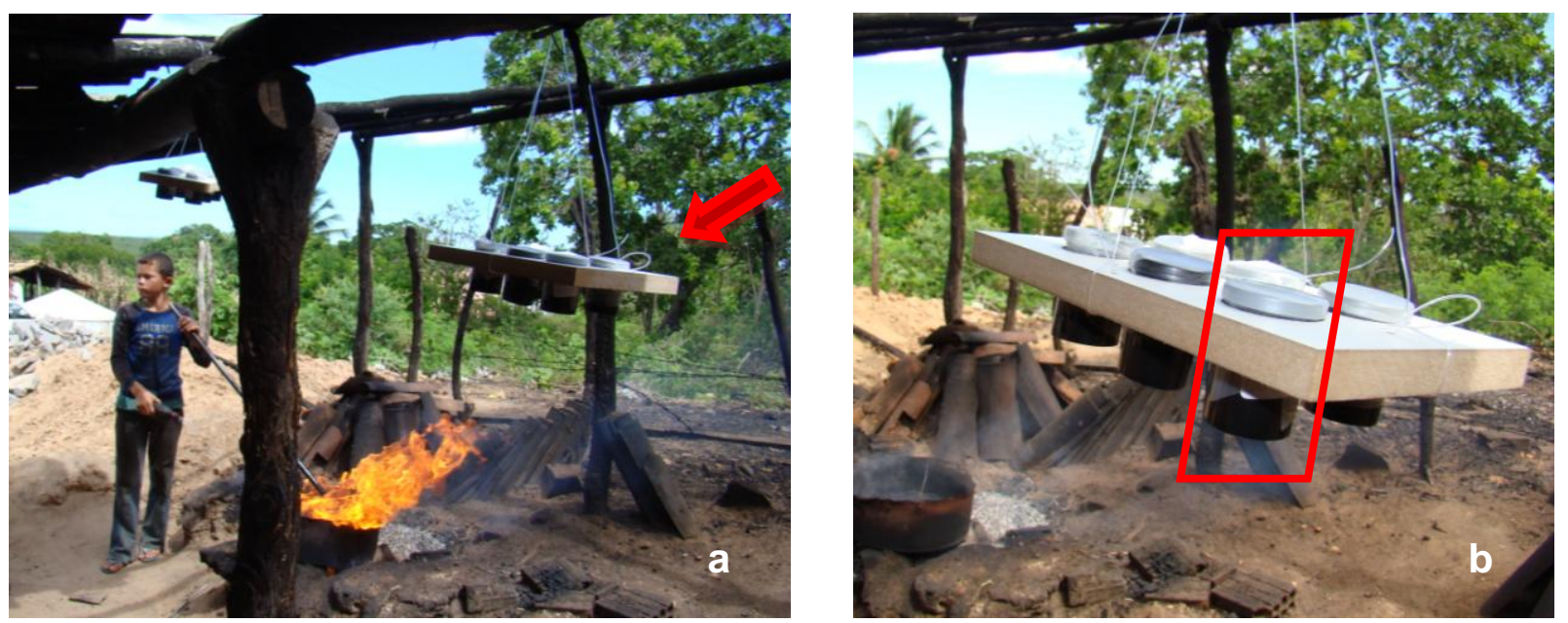

Figura 8. a e b - Tubos passivos contendo filtros absorventes para avaliação da concentração de $\mathrm{O}_{3}$ e $\mathrm{NO}_{2}$. $\mathbf{b}$ - Em vermelho - destaque para um tubo passivo. 


\subsubsection{Ozônio (O3)}

Os tubos passivos utilizados para amostragem de $\mathrm{O} 3$ eram compostos por filtros de celulose, diâmetro $37 \mathrm{~mm}$, da marca Energética (Energética qualidade do ar). Para ativação, os filtros foram cobertos com solução absorvente de Indigo Carmin por 3 minutos. Transcorrido os 3 minutos a solução foi desprezada e os filtros permaneceram na estufa $80^{\circ} \mathrm{C}$ por mais 30 minutos. Após a secagem na estufa, os filtros preparados (apresentando coloração azul - Figura 9) foram submetidos a uma medição de reflectância inicial. Após a primeira medição, os filtros foram protegidos da luz com papel alumínio até o momento da exposição no local teste.

\section{a) Preparação da Solução Absorvente}

Para a preparação da solução absorvente usada nos filtros de $\mathrm{O}_{3}$ foi dissolvido $2 \mathrm{~g}$ de Índigo Carmin em $200 \mathrm{~mL}$ de água destilada, tendo o cuidado de proteger a solução da luz. Após ocorrer a dissolução, o volume foi completado para $1000 \mathrm{~mL}$. A solução foi acondicionada em temperatura ambiente e protegida de luz, com o prazo de validade de três semanas.

\section{b) Medição da concentração de $\mathrm{O}_{3}$}

Após a exposição dos filtros, ocorre uma reação entre o ozônio e o índigo. O ozônio converte uma parte do índigo em duas partes de isatina. Essa reação gera uma mudança de azul (índigo) em amarelo (isatina) que é medida pelo método de reflectância, ou seja, é medida a reflectância final. O resultado da medida de reflectância foi obtido pela diferença entre a reflectância final e a inicial.

\subsubsection{Dióxido de Nitrogênio (NO2) (James P. Lodge 1988)}

Os tubos passivos utilizados para amostragem de NO2 eram da mesma fabricação que aqueles usados para preparação dos filtros de O3. Para ativação dos filtros foi gotejado $200 \mu \mathrm{l}$ de solução absorvente em cada filtro. Em seguida, os filtros foram levados a estufa a $37^{\circ} \mathrm{C}$ onde permanecem por 24 horas para secagem e posterior exposição ao ambiente. 


\section{a) Preparação da Solução Absorvente}

Em $500 \mathrm{~mL}$ de água destilada previamente fervida (para retirada de $\mathrm{Cl}$ ) ou água ultrapura foram dissolvidos: $1^{\circ} 17,79 \mathrm{~mL}$ de Trietanolamina; $2^{\circ} 0,45 \mathrm{~mL}$ de Ometoxyfenol (guaiacol); $3^{\circ}$ 0,25 mg de Metabissulfito de Sódio. Após a dissolução dos solutos, o volume da solução foi completado para $1000 \mathrm{~mL}$. A solução absorvente era estocada em geladeira, permanecendo válida por 2 semanas.

\section{b) Medição da concentração de $\mathrm{NO}_{2}$}

Após a exposição, cada filtro foi colocado em um becker de $100 \mathrm{~mL}$, onde foi adicionado $50 \mathrm{~mL}$ de álcool metílico. Cada becker foi fechado com parafilm e levado para o banho de ultrassom por 3 minutos para que ocorresse a extração do material acumulado. Em $5 \mathrm{~mL}$ do material extraído, foi acrescentado $0,15 \mathrm{~mL}$ de peróxido de hidrogênio (30\%). A mistura foi agitada, e após 15 e 30 segundos foram acrescentados e homogeneizado $2,7 \mathrm{~mL}$ de sulfanilamida, e 3,0 $\mathrm{mL}$ de ANSA respectivamente.

A leitura das amostras foi realizada em espectrofotômetro a $550 \mathrm{~nm}$ no período de 10 a 40 minutos após a adição de ANSA. Inicialmente foi realizada a leitura nos tubos da curva de calibração e depois nas amostras. Os resultados obtidos foram relativos ao tempo de exposição e expressos em $\mu \mathrm{g} / \mathrm{m} 3$.
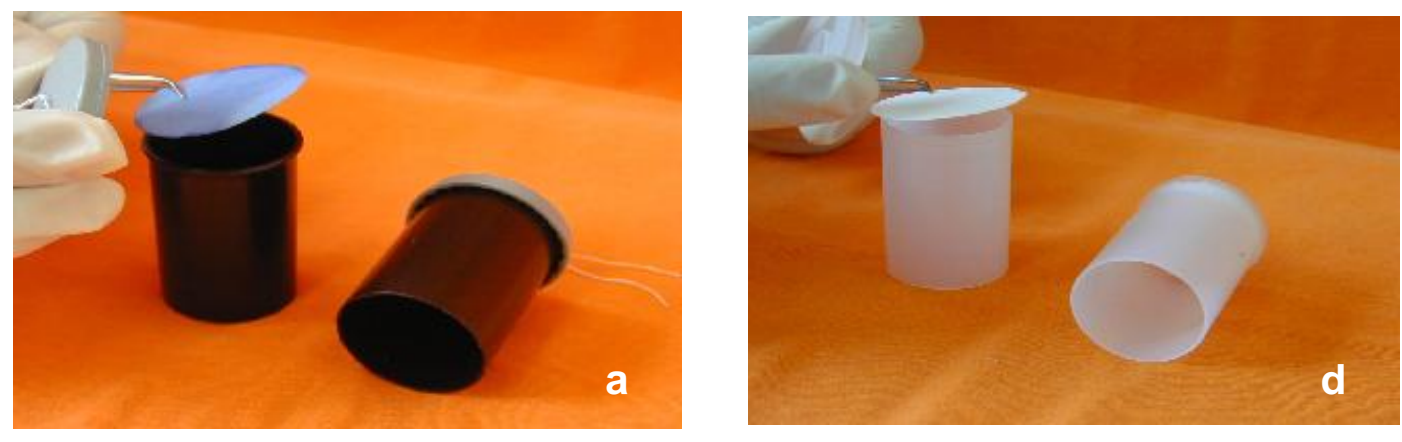

Figura 9. Montagem dos tubos passivos. a - $\mathrm{O}$ filtro de $\mathrm{O}_{3}$ apresenta coloração azul; $\mathbf{b}$ filtro de $\mathrm{NO}_{2}$ apresenta cor branca. 


\subsubsection{Quantificação do material particulado com o uso de amostradores} ativos

Entre os produtos gerados pelo processo de combustão destaca-se o material particulado (MP). O material particulado foi medido com o auxílio de dois amostradores ativos distintos. De modo semelhante ao posicionamento dos tubos passivos, os dois equipamentos foram devidamente posicionados nos três pontos testes a uma altura média de 1,60 m, que corresponde aproximadamente à altura em que os trabalhadores que participam do processo de beneficiamento da castanha de caju respiram. Inicialmente, no período de 30/04/07 a 31/05/2007 o material particulado foi medido com o medidor portátil "DUSTTRAK ${ }^{\text {TM }}$ Aerossol Monitor" (Figura 10). Em seguida, foi utilizado o amostrador Mini-sampler nos meses de Janeiro de 2009, Maio de 2009 e Setembro de 2009. Esses intervalos foram escolhidos com o objetivo de verificar a concentração e caracterização do material particulado inalado pelos trabalhadores em diferentes períodos do ano, sendo possível avaliar a influencia das alterações climáticas entre o período seco, chuvoso e intermediário.

\subsubsection{DUSTTRAK ${ }^{\mathrm{TM}}$ Aerossol Monitor (MP 10ųm, 2,5ųm e 1,0ųm)}

O medidor portátil "DUSTTRAK ${ }^{\mathrm{TM}}$ Aerossol Monitor" (Modelo 8520 - TSI Inc.) foi utilizado para quantificar a concentração de MP em suspensão com diâmetro igual ou inferior a 10 ųm, 2,5 ųm e 1,0 ųm, para os pontos 1 e 3 . Para o ponto 2, foi realizado medições apenas para o MP 2,5. Esse equipamento tem um sensor (laser photometer - $90^{\circ}$ light scattering, laser diode) que realiza medições da concentração em massa de material particulado no ar, o qual é aspirado do meio ambiente por uma bomba interna. O aparelho possui capacidade de realizar medições em um espectro muito amplo, que varia de $0,001 \mathrm{mg} / \mathrm{m}^{3}$ a $100 \mathrm{mg} / \mathrm{m}^{3}$, com precisão de $\pm 0,1 \%$. 0 registro das informações é realizado a cada minuto de forma automática na memória do próprio equipamento. 

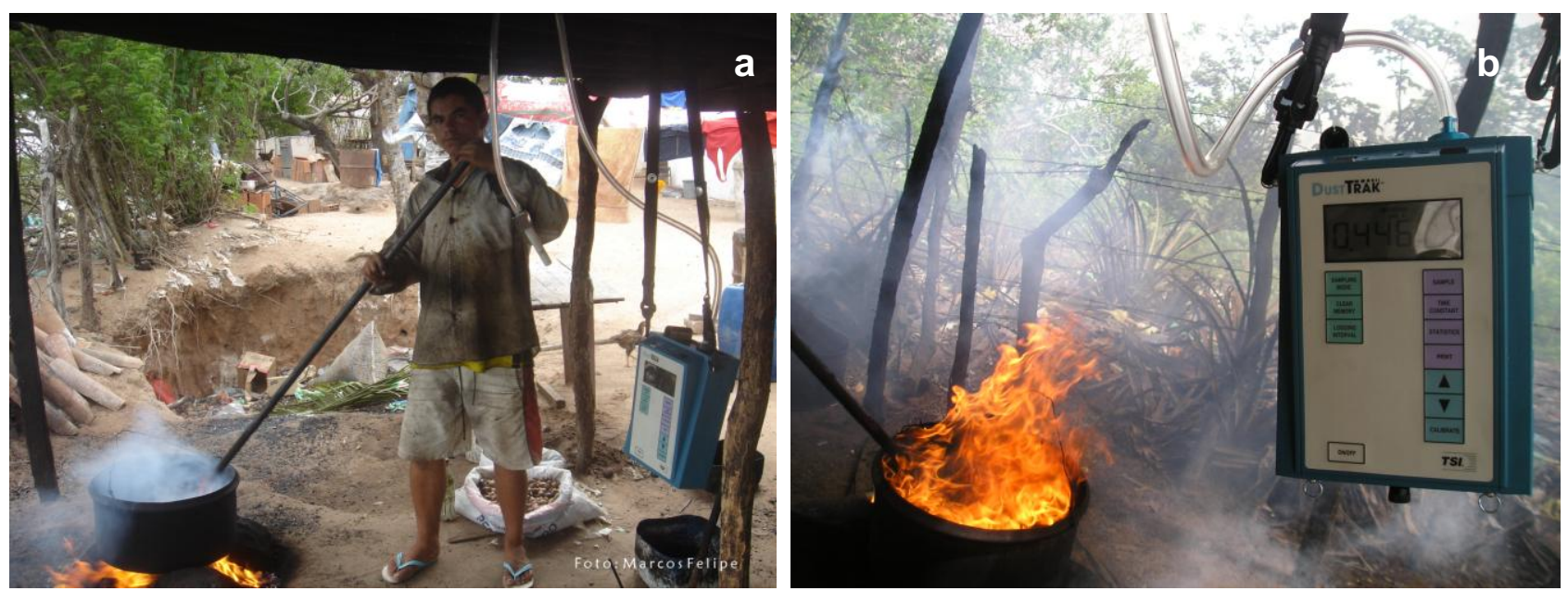

Figura 10. a - "DUSTTRAK ${ }^{\mathrm{TM}}$ Aerossol Monitor" posicionado próximo aos trabalhadores; b - Equipamento apresentando o monitor digital com resultado da medição do MP.

\subsubsection{Mini-sampler (MP $\leq 2,54 \mathrm{~m})$}

O Mini-sampler é um equipamento com capacidade de concentrar o material particulado na fração respirável (MP $\leq 2,5$ ųm) do meio ambiente em um filtro (Figura 11). O equipamento é composto basicamente por uma sonda e um gabinete. A sonda se comunica com o meio externo por uma entrada de ar, e com o gabinete por meio de uma mangueira de látex. A sonda é o elemento responsável por selecionar o tamanho aerodinâmico do material particulado que será acumulado no filtro posicionado na própria sonda. O gabinete possui uma bomba de vácuo, um horímetro e um medidor de pressão. A bomba de vácuo é responsável pelo fluxo de ar, o qual foi regulado para um fluxo de 1,8 lpm. O horímetro auxilia no registro de tempo de exposição, e o medidor de pressão permite verificar eventuais momentos de saturação do filtro.

As amostragens ocorreram nos três pontos testes, e em três diferentes campanhas de exposição. O material particulado presente no ambiente foi concentrado em filtros de policarbonato de $37 \mathrm{~mm}$. Para cada campanha foram utilizados 10 filtros em cada ponto, totalizando 30 filtros por campanha, e 90 filtros para as três campanhas realizadas. Essas campanhas ocorreram simultaneamente a três dos quatro períodos em que houve a realização de testes de genotoxicidade em T. pallida (Janeiro, Maio e Setembro de 2009). 

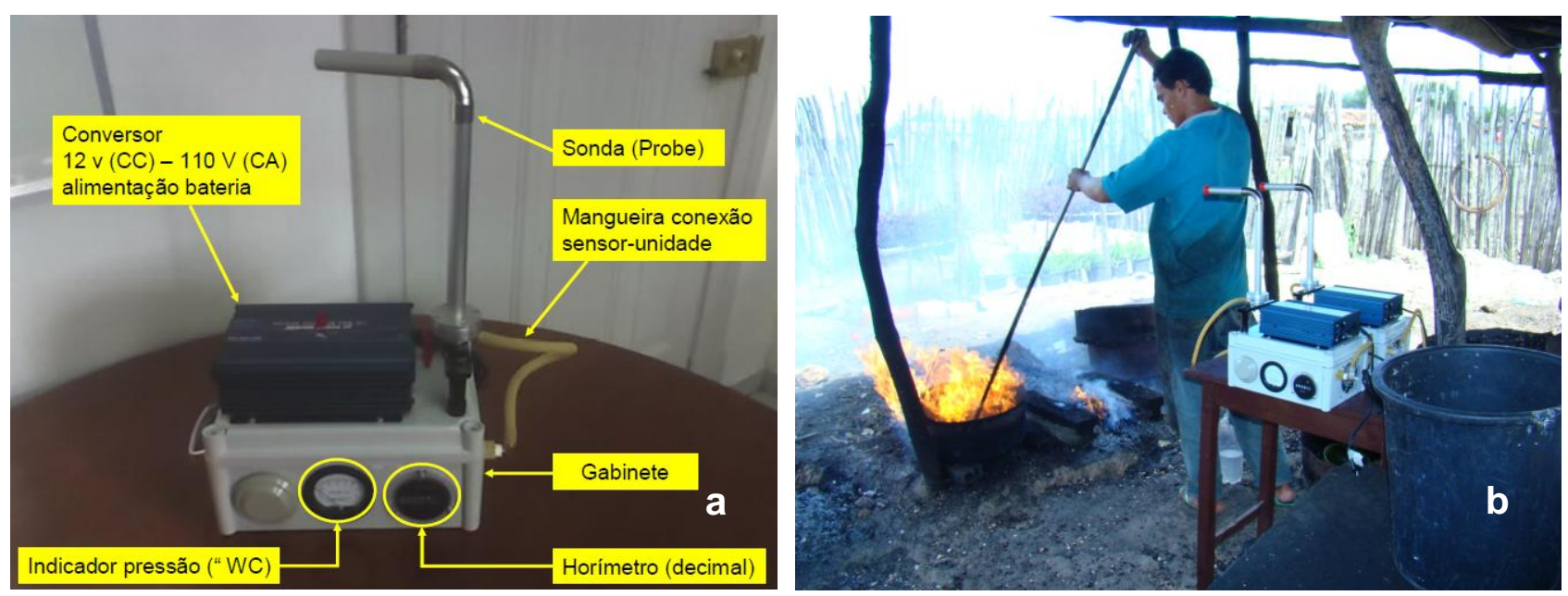

Figura 11. "Mini-sampler". a - Amostrador ativo destacando os diferentes componentes constituintes do equipamento (NEP/LPAE-FMUSP 2008). b - Equipamento posicionado próximo aos trabalhadores do beneficiamento artesanal da castanha de caju.

\subsubsection{Análise da composição do MP acumulado nos filtros de} policarbonato

Os filtros foram submetidos a vários testes, com o objetivo de caracterizar o material particulado acumulado. Os parâmetros analisados foram: concentração de material particulado na fração respirável (MP 2,5 ųm), Black Carbon e composição elementar. O resultado foi apresentado como quantidade de elemento acumulado por área do filtro em $\mu \mathrm{g} / \mathrm{m}^{3}$.

A concentração do material particulado foi determinada com auxílio da análise gravimétrica e a determinação das concentrações de carbono elementar ("Black Carbon" - BC) pela técnica de reflectância de luz. A análise elementar foi realizada com a técnica de fluorescência de Raio-X.

\subsubsection{Determinação Gravimétrica de Massa}

Todos os filtros amostrados foram submetidos à análise gravimétrica, sendo pesados antes e depois da amostragem em uma balança eletrônica de precisão nominal $1 \mu \mathrm{g}$. Neste procedimento, antes da pesagem, os filtros foram submetidos a ação de fontes de Po210 a fim de serem descarregados eletrostaticamente. 


\subsubsection{Análise de Reflectância}

Para determinação das concentrações de carbono elementar ("Black Carbon” $\mathrm{BC})$ presentes nas amostras, foi utilizada a técnica de reflectância de luz induzida pelo particulado, com um Reflectômetro, marca "Diffusion Systems Ltd." modelo "Smoke Stain Reflectometer-Model 43" (Yamasoe et al. 2000). O dado obtido com esse equipamento foi resultado da absorção de luz pelo particulado depositado no filtro. A fração do particulado que é absorvedora de radiação (gerada por uma lâmpada de Tungstênio) é classificada como BC, constituído em boa parte pelo carbono elementar.

A técnica de reflectância consiste na incidência de luz de uma lâmpada de Tungstênio no filtro amostrado, o qual reflete uma intensidade inversamente proporcional à quantidade de $\mathrm{BC}$ presente. Como as partículas de BC são boas absorvedoras de luz, quanto maior a sua presença, menor a intensidade de luz refletida pelo filtro e menor a detectada pelo fotosensor.

\subsubsection{Análise de Fluorescência de raios-X}

As amostras de material particulado foram analisadas para a determinação da composição elementar pela técnica de fluorescência de raios-X. A fluorescência de raios-X é uma técnica que permite análise qualitativa e quantitativa da amostra, e desse modo, é possível estabelecer a proporção em que cada elemento se encontra. Nessa técnica todos os elementos da amostra são excitados ao mesmo tempo e o detector de energia dispersiva, juntamente com um analisador multicanal é usado para simultaneamente detectar a radiação fluorescente emitida da amostra e separar as diferentes energias de radiação característica de cada elemento presente. $O$ procedimento ocorre de modo que em uma câmara de vácuo o feixe atinge a amostra de aerossol, colidindo com os átomos desta e removendo os elétrons das camadas eletrônicas mais internas. As vacâncias nestas camadas são preenchidas por elétrons de camadas mais externas, e nessa transferência ocorre liberação de energia característica de cada elemento, a qual é emitida como raios- $X$, possibilitando a identificação química do elemento (Johansson \& Campbell 1988). Assim, na análise de FRX têm-se três fases: $1^{\circ}$ excitação dos elementos que constituem a amostra; $2^{\circ}$ dispersão dos raios $X$ característicos emitidos pela amostra; $3^{\circ}$ detecção dos raios 
emitidos pela amostra após excitação. No presente estudo os elementos identificados foram: Mg, Al, Si, P, S, Cl, K, Ca, Ti, V, Cr, Mn, Fe, Ni, Cu, Zn, Se, Br, e Pb.

3.3. Classificação e caracterização da espécie utilizada como biomonitor Tradescantia pallida (Rose) D.R. Hunt. Var. purpúrea.

\subsubsection{Classificação}

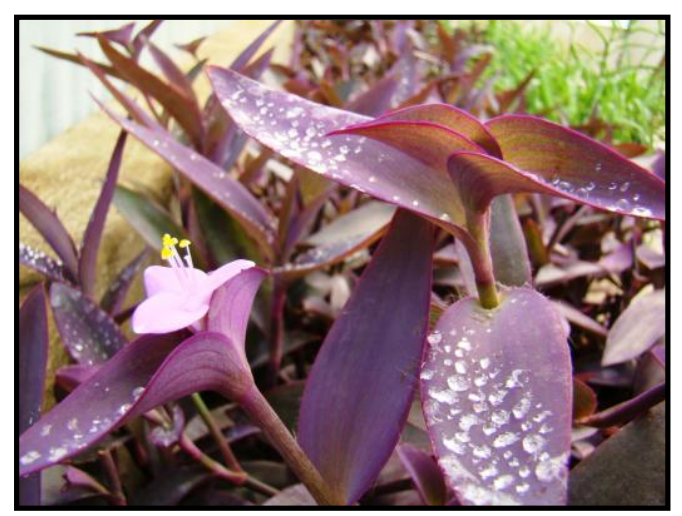

Figura 12. Tradescantia pallida (Rose) D.R. Hunt var. purpúrea.

CLASSE - Liliopsida

ORDEM - Commelinales

FAMILIA - Commelinaceae

GENERO - Tradescantia

ESPÉCIE - Tradescantia pallida

\subsubsection{Caracterização}

A escolha e manutenção dos organismos são de fundamental importância para realização dos ensaios ecotoxicológicos. A Tradescantia pallida (Rose) D.R. Hunt var. purpúrea (Figura 12) é uma espécie pertencente à família das Commelinaceae, nativa da região da América do Norte e Central (México e Honduras), do tipo herbácea, com folhas roxas e pubescentes (USDA, 2007). A espécie apresenta fácil adaptação em diferentes ambientes e se desenvolve durante todo o ano. No Brasil ela vem sendo utilizada como planta ornamental, sendo comum a espécie ser encontrada nos canteiros de diversas cidades no Rio Grande do Norte. Como organismo biomonitor, esta espécie tem sido freqüentemente relatada em estudos de genotoxicidade ao 
redor do mundo (Cavas \& Ergene-Gozukara 2005b, 2005a; da Silva Souza \& Fontanetti 2006; Souza \& Fontanetti 2006; Misík et al. 2007; Savóia et al. 2009).

\subsection{Testes de genotoxicidade}

\subsubsection{Teste de Micronúcleo em T. pallida (Ma 1981; Ma et al. 1994b)}

As mudas de T. pallida foram propagadas a partir de uma única muda. Essa homogeneidade genética teve o objetivo de evitar diferenças na sensibilidade dos biomonitores frente aos possíveis compostos mutagênicos devido a variações genéticas individuais.

As plantas foram propagadas e cultivadas em 30 floreiras plásticas com $50 \mathrm{~cm}$ de comprimento por $17 \mathrm{~cm}$ de altura. Utilizou-se uma mistura de solo padronizada, a fim de que possíveis variações no tipo de solo e deficiências quanto à disponibilidade de nutrientes não comprometessem a avaliação. A mistura de solo foi composta por: duas partes de terra vegetal, uma parte do substrato Eucatex® Plantmax HT, uma parte de vermiculita fina e uma parte de húmus de minhoca (2:1:1:1 v/v) (Figura 13 a). Todas as floreiras foram mantidas numa casa de vegetação em condições de temperatura e umidade constantes de $30 \pm 2^{\circ} \mathrm{C}$ e $70 \%$, respectivamente (Figura 13 b e c). As plantas foram regadas com água destilada diariamente, tanto no período de propagação como nos períodos de aclimatação e exposição. Além disto, nenhum pesticida foi aplicado sobre ou próximo às plantas durante o período de propagação ou experimental.

Antes da primeira coleta, as plantas passaram por um período de adaptação de um mês nos três pontos testes. Para cada ponto teste, 30 inflorescências jovens foram coletadas e fixadas em solução de ácido acético 45 \% e álcool etílico 70 \% (1:3 $\mathrm{v} / \mathrm{v}$ ) por 48 horas, e em seguida preservadas em álcool etílico $100 \%$, conforme adaptação do protocolo estabelecido por Ma e colaboradores (Ma 1981; Ma et al. 1994a). Foram realizadas quatro coletas de inflorescências nos três pontos testes: Setembro de 2008, Janeiro de 2009, Maio de 2009 e Setembro de 2009. Todas as coletas ocorreram em meses com intensa atividade de beneficiamento da castanha de caju na Comunidade do Amarelão. 

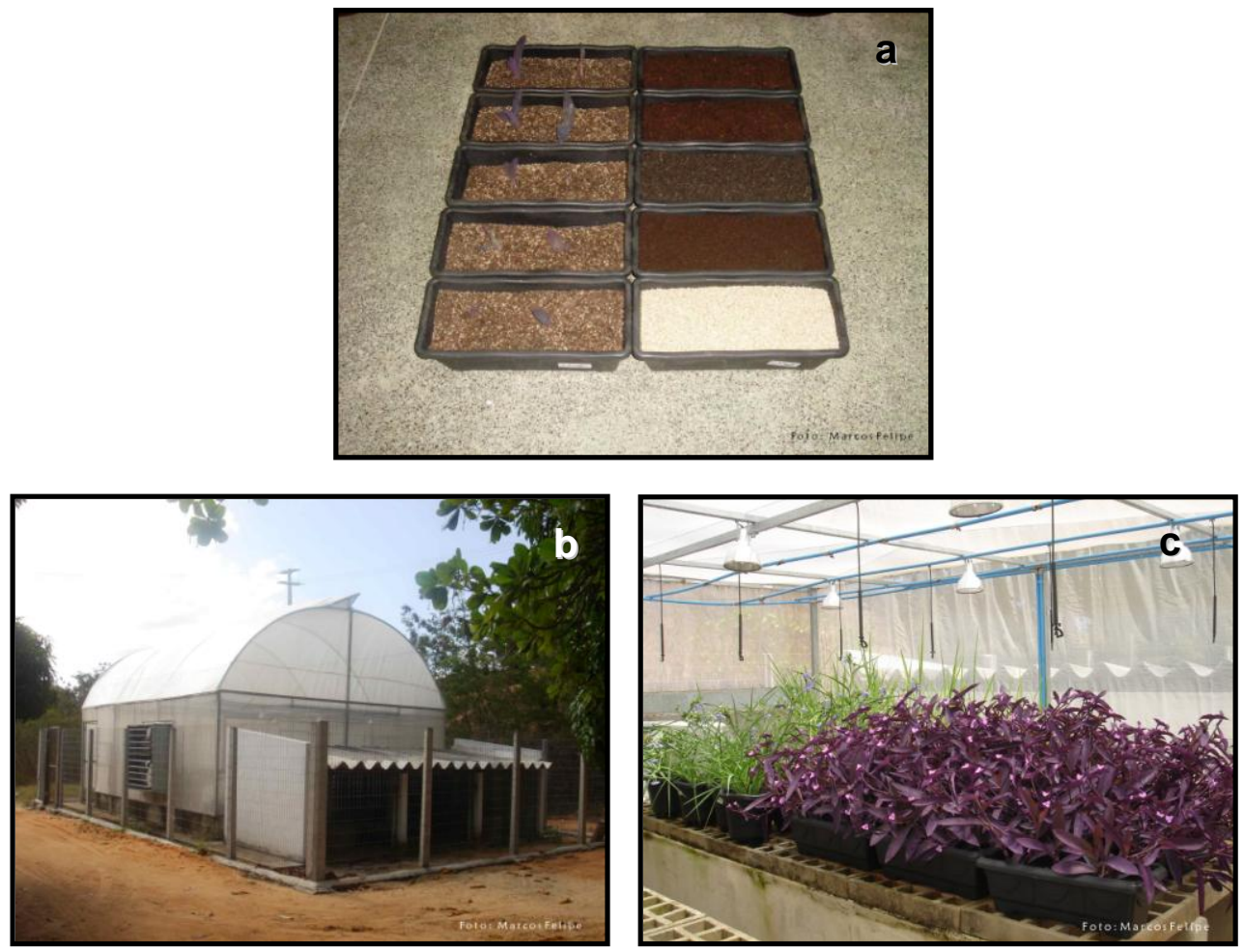

Figura 13. a - Floreiras contendo os diferentes compostos utilizados na preparação do solo; b - Casa de vegetação onde foi realizada a propagação das mudas antes do período experimental; c - Mudas prontas para serem levadas para campo.

\subsubsection{Preparação e análise citológica}

A preparação citológica incluiu inicialmente a escolha do botão floral apropriado contendo o estágio de tétrade. Com o auxilio de uma pinça os botões florais foram abertos e as anteras maceradas. Em seguida, foi acrescentado o corante acetato de carmim a 2 \% sobre uma lâmina de microscopia. Após o posicionamento da lamínula, a lâmina foi rapidamente aquecida a aproximadamente $80^{\circ} \mathrm{C}$ para melhor fixação do corante e pressionada entre folhas de papel absorvente para remover o excesso de corante, de modo a garantir com que as tétrades ficassem posicionadas num mesmo plano de visualização (Figura 14). 


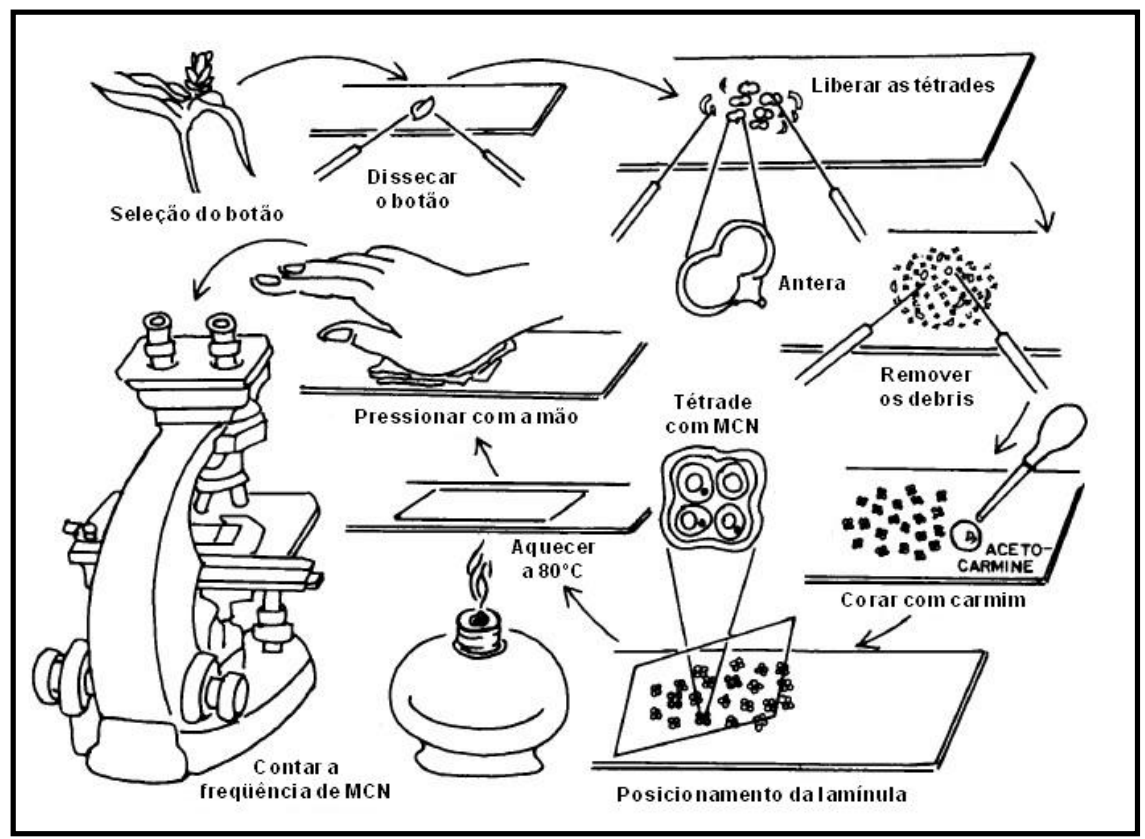

Figura 14. Esquema da preparação citológica. Adaptado de Ma (1981) (Ma 1981).

A análise foi realizada a partir da quantificação do número de micronúcleos presentes num grupo aleatório de 300 tétrades por lâmina. A contagem foi realizada em microscopia óptica com aumento de $400 \mathrm{X}$. O número total de lâminas analisadas foi de 10 lâminas, equivalendo a 3000 tétrades por ponto. Para a análise, as células contadas obedeceram aos critérios pré-estabelecidos por Tolbert e colaboradores (Tolbert et al. 1992; Holland et al. 2008): a) Células dispostas em uma posição plana com relação à lâmina, e presença do citoplasma intacto; b) Presença de núcleo normal e intacto; c) Pouca ou nenhuma sobreposição com as células adjacentes; d) Existência de pouco, ou nenhum debris (restos ou fragmentos de células) no campo analisado. Para identificação e quantificação dos micronúcleos, os critérios foram: a) MN com perímetro bem delimitado, sugerindo a presença de membrana; b) Coloração e textura do $\mathrm{MN}$ semelhante a do núcleo da célula analisada; c) Localização do $\mathrm{MN}$ no mesmo plano focal do núcleo, d) Ausência de sobreposição ou presença de pontes interligando o MN ao núcleo. 


\subsubsection{Teste de Micronúcleo em mucosa oral humana (Holland et al. 2008)}

\subsubsection{Escolha dos participantes voluntários da pesquisa}

Para a análise de mucosa oral foram selecionadas 90 pessoas voluntárias com idade igual ou superior a 18 anos, que assinaram o "Temo de consentimento Livre e Esclarecido" aprovado pelo comitê de ética em pesquisa da Faculdade de Medicina da Universidade de São Paulo (FMUSP) e Universidade Federal do Rio Grande do Norte (UFRN). Para melhor caracterizar os trabalhadores do beneficiamento da castanha de caju e o grupo controle da pesquisa, todos os participantes (expostos e não expostos aos poluentes da queima da castanha) responderam um questionário abordando informações sobre idade, sexo, número de filhos, tempo que trabalha na atividade que desenvolve atualmente, duração da jornada diária de trabalho, exerce o hábito de fumar, havia estado em consultório odontológico na semana da coleta do material de mucosa oral, possui o hábito de consumir bebida alcoólica, ocorrência de abortos espontâneos e existência de casos de câncer na família (Anexo VI).

Os 90 voluntários foram divididos em dois grupos: Grupo 1 - 45 trabalhadores envolvidos diretamente com a atividade do beneficiamento da castanha de caju e moradores da Comunidade do Amarelão; Grupo 2 - 45 voluntários não expostos aos poluentes oriundos do beneficiamento da castanha de caju e moradores de regiões próximas, mas sem influencia da atividade.

\subsubsection{Preparação e análise citológica}

Para análise citológica, foram contadas mil células para cada indivíduo, e o número de micronúcleos encontrados foi apresentado em relação ao número de micronúcleos por mil células (MN/1000).

As células de mucosa oral foram retiradas a partir do leve atrito de uma espátula de madeira (abaixador de língua) com a mucosa oral de cada voluntário (Figura 15). Sendo utilizada uma espátula para cada lado da boca. As espátulas contendo as células foram imersas em tubos Falcon contendo solução fisiológica e mantidas em banho de gelo até chegar ao laboratório. O material coletado foi centrifugado por três vezes a 1500 RPM por 8 minutos, sendo trocado a solução fisiológica em cada ciclo de centrifugação. Este procedimento foi realizado para 
remover bactérias e restos celulares (debris), os quais podem dificultar a análise. Depois da última centrifugação o pellet foi ressuspendido em $500 \mu \mathrm{L}$ de solução fisiológica e espalhado em no mínimo duas lâminas. As lâminas contendo as amostras ficaram expostas por 48 horas para secar a temperatura ambiente. Após a secagem, as células foram hidrolizadas em $\mathrm{HCl}(1 \mathrm{~N})$ a $60^{\circ} \mathrm{C}$ por 10 minutos. $\mathrm{A}$ coloração foi realizada pelo reativo de Shiff por 3 a 4 horas protegido da luz. Após o período de coloração as lâminas foram lavadas com água destilada, tornando-se prontas para análise ao microscópio óptico pelo aumento de $400 \mathrm{X}$. Para a análise, as células contadas obedeceram aos critérios pré-estabelecidos por Tolbert e colaboradores (Tolbert et al. 1992; Holland et al. 2008) e já citados no item anterior (3.4.1. Teste de Micronúcleo em T. pallida).

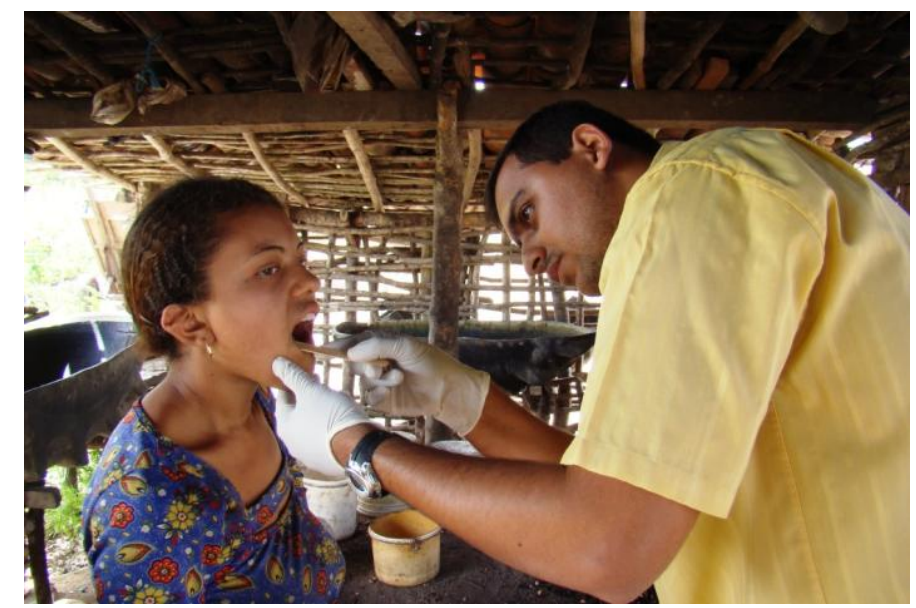

Figura 15. Coleta de células de mucosa oral humana realizada na Comunidade do Amarelão em beneficiadores da castanha de caju. 


\subsection{Análise estatística}

Para verificar se os resultados obtidos apresentavam distribuição normal, foi realizado o teste de Anderson-Darling com $\alpha=0,05$ (Dado normal quando $P \geq \alpha$ ). Para o cálculo da tendência central da amostra foi realizado o cálculo de média para todos os resultados. Os resultados que não apresentavam distribuição normal além da média foi realizado o cálculo da mediana. A dispersão dos resultados foi verificada pelo cálculo do Desvio Padrão (DP) para os resultados que apresentaram distribuição normal, e da Distância Interquartílica (IQR) para aqueles que não apresentaram distribuição normal.

Exceto para a concentração do MP realizada pelo "DUSTTRAK ${ }^{\mathrm{TM}}$ Aerossol Monitor", os resultados dos indicadores de exposição a poluentes ambientais, tais como, $\mathrm{O}_{3}, \mathrm{NO}_{2}, \mathrm{MP}, \mathrm{BC}$ e composição elementar não apresentaram distribuição normal, e desse modo, foi realizado o teste não paramétrico de Kruskal-Wallis para determinar se haviam diferenças significativas entre os resultados $(P \leq 0,05)$. Esses resultados foram submetidos à Correlação de Spearman para verificar o grau de relacionamento entre as variáveis estudadas. Para a avaliação da ocorrência de diferenças significativas na concentração de Material Particulado realizado com o medidor "DUSTTRAK ${ }^{\mathrm{TM}}$ Aerossol Monitor" foi realizado o cálculo da Análise de Variância (ANOVA com um fator - $P \leq 0,05$ ) devido aos resultados apresentarem distribuição normal.

Os dados referentes aos testes micronúcleo em T. pallida e em mucosa oral também foram submetidos ao teste de normalidade e apresentaram distribuição normal, sendo utilizado, portanto, a Análise de Variância $(P \leq 0,05)$ para verificar a existência de diferenças significativas entre os resultados. As análises estatísticas foram obtidas com a utilização do Software Minitab 15 e do Microsoft Excel ${ }^{\circledR}, 2007$. 


\section{RESULTADOS}

\subsection{Indicadores de exposição a poluentes ambientais}

\subsubsection{Ozônio (03) e Dióxido de Nitrogênio (NO2)}

Foram realizados medições de $\mathrm{O}_{3}$ e $\mathrm{NO}_{2}$ nos três pontos testes nos meses de janeiro, maio e setembro de 2009. Os resultados obtidos indicaram concentrações inferiores aos padrões do CONAMA e da OMS (Referencia) em todos os pontos durante os três períodos estudados. As medianas e distância interquartílica, médias e DP dos resultados obtidos podem ser visualizados na Tabela 1.

No mês de janeiro, a concentração de $\mathrm{O}_{3}$ foi significativamente mais alta para o ponto $2\left(21,63 \mu \mathrm{g} / \mathrm{m}^{3}\right)$ que para os Pontos 1 e 3 . Os dois últimos não apresentaram diferenças significativas entre eles sendo $11,0 \mu \mathrm{g} / \mathrm{m}^{3}$ e $8,5 \mu \mathrm{g} / \mathrm{m}^{3}$ as respectivas medianas.

No mês de maio foram verificadas as menores concentrações $\left(\mathrm{O}_{3}\right)$ entre as campanhas de exposição nos três pontos. As concentrações para os Pontos 1,2 e 3 não apresentaram diferenças significativas (Ponto $1-4,3 \mu \mathrm{g} / \mathrm{m}^{3}$; Ponto $2-7,95 \mu \mathrm{g} / \mathrm{m}^{3}$; e Ponto $3-8,04 \mu \mathrm{g} / \mathrm{m}^{3}$ ). Em setembro foi verificado as maiores concentrações de $\mathrm{O}_{3}$ nos três pontos estudados. Nesse mês a concentração para o Ponto 2 foi significativamente mais alta $\left(96,72 \mu \mathrm{g} / \mathrm{m}^{3}\right)$ que o Ponto $1\left(53,8 \mu \mathrm{g} / \mathrm{m}^{3}\right)$, e o Ponto 1 significativamente mais alto que o Ponto $3\left(21,73 \mu \mathrm{g} / \mathrm{m}^{3}\right)$.

Para o $\mathrm{NO}_{2}$, no mês de janeiro os resultados obtidos para os Pontos 1, 2 e 3 foram $16,75 \mu \mathrm{g} / \mathrm{m}^{3} ; 28,6 \mu \mathrm{g} / \mathrm{m}^{3}$ e $14,9 \mu \mathrm{g} / \mathrm{m}^{3}$ respectivamente. Em janeiro a concentração do Ponto 2 foi significativamente maior. Nos meses de maio e setembro não houve diferenças significativas entre os resultados: Maio: Ponto $1-35,35 \mu \mathrm{g} / \mathrm{m}^{3}$; Ponto $2-31,77 \mu \mathrm{g} / \mathrm{m}^{3}$; Ponto $3-28,91 \mu \mathrm{g} / \mathrm{m}^{3}$; Setembro: Ponto $1-23,05 \mu \mathrm{g} / \mathrm{m}^{3}$; Ponto $2-22,32 \mu \mathrm{g} / \mathrm{m}^{3}$; Ponto $3-17,61 \mu \mathrm{g} / \mathrm{m}^{3}$. No mês de maio foi verificado as maiores concentrações de $\mathrm{NO}_{2}$ entre as três campanhas, tendo os Pontos 1 e 2 atingido valores significativamente maiores que as outras campanhas. 
Tabela 1: Medições da concentração de $\mathrm{O}_{3}$ e $\mathrm{NO}_{2}$ para os meses de Janeiro, Maio e Setembro de 2009, relativo à quantidade de elemento acumulado por área do filtro $\left(\mu \mathrm{g} / \mathrm{m}^{3}\right)$ em um dia de exposição. A tendência central dos resultados foi apresentada como Mediana e Média e a dispersão como Distância Interquartílica (IQR) e Desvio Padrão (DP). O Ponto 1 representa a Comunidade do Amarelão, Ponto 2 a Fazenda Santa Luzia e o Ponto 3 a UFRN.

\begin{tabular}{|c|c|c|c|c|c|c|c|c|c|c|}
\hline \multirow{2}{*}{\multicolumn{2}{|c|}{ Elemento }} & \multicolumn{3}{|c|}{ Janeiro - 2009} & \multicolumn{3}{|c|}{ Maio - 2009} & \multicolumn{3}{|c|}{ Setembro - 2009} \\
\hline & & Ponto 1 & Ponto 2 & Ponto 3 & Ponto 1 & Ponto 2 & Ponto 3 & Ponto 1 & Ponto 2 & Ponto 3 \\
\hline \multirow{3}{*}{$\mathrm{O}_{3}$} & Mediana & 11,0 & $21,63^{\star b}$ & 8,5 & 4,3 & 7,95 & 8,04 & $53,8^{* a}$ & $96,72^{\star \star C}$ & $21,73^{d}$ \\
\hline & IQR & 2,6 & 2,8 & 5,8 & 12,6 & 7,95 & 7,58 & 34,48 & 26,04 & 10,69 \\
\hline & Média \pm DP & $11,44 \pm 1,9$ & $21,78 \pm 2,4$ & $8,9 \pm 3,5$ & $7,36 \pm 6,3$ & $9,18 \pm 4,46$ & $7,98 \pm 4,1$ & $54,4 \pm 19,6$ & $90,6 \pm 19,4$ & $19,3 \pm 8,1$ \\
\hline \multirow{3}{*}{$\mathrm{NO}_{2}$} & Mediana & 16,75 & $28,6^{*}$ & $14,9^{d}$ & $35,35^{a}$ & $31,77^{b}$ & 28,91 & 17,6 & 22,32 & 23,05 \\
\hline & IQR & 2,5 & 7,29 & 4,86 & 15,1 & 5,87 & 5,2 & 10,23 & 7,09 & 9,02 \\
\hline & Média \pm DP & $17,56 \pm 2,5$ & $27,3 \pm 3,96$ & $15,5 \pm 2,4$ & $35,7 \pm 7,6$ & $32,35 \pm 3,5$ & $30,4 \pm 3,9$ & $19,2 \pm 5,0$ & $22,3 \pm 3,7$ & $25,9 \pm 8,0$ \\
\hline
\end{tabular}

* ${ }^{* *}$ Correspondem aos resultados que diferiram significativamente entre os três pontos em uma mesma campanha de exposição $(\mathrm{P} \leq 0,05)$.

"a" Corresponde ao resultado que diferiu significativamente para o Ponto 1 entre as três campanhas de exposição para $\mathrm{O}_{3}$ e $\mathrm{NO}_{2}$ $(P \leq 0,05)$.

"b" e "c" Correspondem aos resultados que diferiram significativamente para o Ponto 2 entre as três campanhas de exposição para $\mathrm{O}_{3}$ e $\mathrm{NO}_{2}(\mathrm{P} \leq 0,05)$.

"d" Corresponde ao valor que diferiu significativamente para o Ponto 3 entre as três campanhas de exposição para $\mathrm{O}_{3}$ e $\mathrm{NO}_{2}$ $(\mathrm{P} \leq 0,05)$. 


\subsection{Quantificação do material particulado (MP 10 ųm, 2,5 ųm e 1,0 ųm)}

Foram realizadas medições de Material Particulado nos três pontos estudados. Os resultados de concentração média, mínimo e máximo encontrados para os três pontos foram apresentados na Tabela 2. No local onde se localiza a comunidade do Amarelão (Ponto 1), todas as frações de Material Particulado analisadas (MP 1,0 ųm; 2,5 ųm e 10 ųm) apresentaram altos valores. Nesse ponto, dentre as oito (8) medições realizadas, sete (7) excederam o nível de exposição definido como "estado de emergência" $\left(500 \mu \mathrm{g} / \mathrm{m}^{3}\right.$ para partículas finas MP 2,5 ųm), diferindo significativamente dos resultados obtidos nos Pontos 2 e 3 . No Ponto 2 foi verificado baixos índices de MP na fração 2,5 ųm, com valor médio de $6 \mu \mathrm{g} / \mathrm{m}^{3}$, sendo esse resultado semelhante ao encontrado no Ponto 3 para o MP 2,5 ųm. Os resultados obtidos para o Ponto 3 foram $6,0 \mu \mathrm{g} / \mathrm{m}^{3} ; 6,0 \mu \mathrm{g} / \mathrm{m}^{3}$; e $9,0 \mu \mathrm{g} / \mathrm{m}^{3}$ para MP $1,0 \mathrm{um} ; 2,5$ ųm e 10 ųm, respectivamente. 
Tabela 2: Medições de MP 1,0 ųm, 2,5 ųm e 10 ųm realizados nos Pontos 1, 2 e 3, bem como os limites presentes na legislação brasileira estabelecidos pela resolução no 03 do CONAMA (CONAMA 003/1990) e níveis máximos presente nas orientações da Organização Mundial de Saúde (WHO 2005b). Ponto 1 representa a Comunidade do Amarelão, Ponto 2 a Fazenda Santa Luzia e o Ponto 3 a UFRN.

\begin{tabular}{ccccccc}
\hline Local & Data & PM & $\begin{array}{c}\text { Duração } \\
(\mathbf{d} / \mathbf{h r} / \mathbf{m i m} / \mathbf{s})\end{array}$ & $\begin{array}{c}\text { Mínima } \\
\left(\mu \mathrm{g} / \mathbf{m}^{3}\right)\end{array}$ & $\begin{array}{c}\text { Máxima } \\
\left(\mu \mathrm{g} / \mathbf{m}^{3}\right)\end{array}$ & $\begin{array}{c}\text { Média } \\
\left(\boldsymbol{\mu g} / \mathbf{m}^{3}\right)\end{array}$ \\
\hline Ponto 1 & $31 / 05 / 2007$ & 1.0 & $00: 01: 30: 00$ & 12,0 & 8731,0 & $1002,0^{\prime}$ \\
Ponto 1 & $25 / 05 / 2007$ & 2.5 & $00: 00: 33: 00$ & 5,0 & 384,0 & $27,0^{1}$ \\
Ponto 1 & $25 / 05 / 2007$ & 2.5 & $00: 00: 26: 00$ & 17,0 & 15014,0 & $1040,0^{2}$ \\
Ponto 1 & $25 / 05 / 2007$ & 2.5 & $00: 01: 29: 00$ & 9,0 & 11580,0 & $1369,0^{2}$ \\
Ponto 1 & $29 / 05 / 2007$ & 2.5 & $00: 02: 59: 00$ & 8,0 & 12425,0 & $753,0^{2}$ \\
Ponto 1 & $30 / 05 / 2007$ & 2.5 & $00: 00: 39: 00$ & 65,0 & 4091,0 & $632,0^{2}$ \\
Ponto 1 & $30 / 05 / 2007$ & 2.5 & $00: 02: 20: 00$ & 52,0 & 49864,0 & $8489,0^{3}$ \\
Ponto 1 & $31 / 05 / 2007$ & 10 & $00: 01: 34: 00$ & 27,0 & 12196,0 & $1745,0^{\text {a }}$ \\
Ponto 2 & $25 / 05 / 2007$ & 2.5 & $03: 20: 53: 00$ & 1,0 & 578,0 & $6,0^{4}$ \\
Ponto 3 & $11 / 05 / 2007$ & 1.0 & $00: 23: 37: 00$ & 3,0 & 13,0 & $6,0^{i i}$ \\
Ponto 3 & $30 / 04 / 2007$ & 2.5 & $07: 23: 07: 00$ & 2,0 & 20,0 & $6,0^{4}$ \\
Ponto 3 & $12 / 05 / 2007$ & 10 & $01: 07: 22: 00$ & 6,0 & 19,0 & $9,0^{\text {b }}$ \\
CONAMA & - & 10 & Anual & Padrão primário* & 50,0 \\
CONAMA & - & 10 & 24 horas** & Padrão primário* & 150,0 \\
CONAMA & - & 10 & 24 horas & Emergência*** & 500,0 \\
OMS & - & 2.5 & 24 horas & & - & 25,0 \\
OMS & - & 10 & 24 horas & & - & 50,0 \\
OMS & - & 2.5 & Anual & & - & 10,0 \\
OMS & - & 10 & Anual & & - & 20,0 \\
\hline
\end{tabular}

i e ii Correspondem aos valores de MP 1,0 que diferiram significativamente;

1, 2, 3 e 4 Correspondem aos valores de MP 2,5 que diferiram significativamente;

a eb Correspondem aos valores de MP 10 que diferiram significativamente;

* Padrão Primário - são as concentrações de poluentes que, quando ultrapassadas, poderão afetar a saúde da população.

** Concentração média em 24 horas de 150 microgramas por metro cúbico de ar, que não deve ser excedida mais de uma vez por ano.

*** Emergência - Nível de qualidade do ar atingido em 24 horas considerado critico pelo CONAMA, indicando risco grave à saúde da população (CONAMA 003/1990). 


\subsection{Análise da composição do Material Particulado acumulado nos filtros de policarbonato pelo Mini-sampler (MP 2,5 ųm)}

$\mathrm{Na}$ figura 16 é possível observar o aspecto dos filtros de policarbonato após a realização de uma campanha de exposição. Na Figura 16 - a é apresentado um filtro completamente saturado de MP 2,5 ųm. Esse resultado foi obtido após um curto período de exposição $(\approx 3 \mathrm{~h})$ na comunidade do Amarelão durante o período de beneficiamento da castanha. Na Figura 16 - b e c é apresentado outros dois filtros que foram expostos nos pontos 3 e 2 respectivamente. Os resultados obtidos para os meses de janeiro, maio e setembro de 2009 para a concentração de MP 2,5 ųm, Black Carbon e composição elementar estão apresentados na Tabela 3.

Durante os três meses estudados, os resultados de MP 2,5 e $B C$ foram significativamente superiores para o Ponto $1 \mathrm{em}$ relação aos Pontos 2 e 3. Para o Ponto 1 , os resultados de MP 2,5 diferiram significativamente entre as três campanhas de exposição, sendo a maior concentração verificada no mês de setembro $\left(782,00 \mu \mathrm{g} / \mathrm{m}^{3}\right)$, seguida pelos meses de maio $\left(486,00 \mu \mathrm{g} / \mathrm{m}^{3}\right)$ e janeiro $\left(114,94 \mu \mathrm{g} / \mathrm{m}^{3}\right)$. O BC apresentou resultados semelhantes entre os meses de maio $\left(46,90 \mu \mathrm{g} / \mathrm{m}^{3}\right)$ e setembro $\left(46,80 \mu \mathrm{g} / \mathrm{m}^{3}\right)$, sendo significativamente superior ao mês de janeiro $\left(8,32 \mu \mathrm{g} / \mathrm{m}^{3}\right)$. Exceto para o Ponto 3, durante o mês de maio, todos os resultados obtidos relativos ao MP e $B C$ para o Ponto 2 e 3 durante todas as campanhas foram similares, não apresentando diferenças significativas para essas duas variáveis. No mês de maio, a concentração de MP 2,5 e $B C$ para o Ponto 3 (MP 2,5 - 73,6 $\mu \mathrm{g} / \mathrm{m}^{3} ; B C-0,86 \mu \mathrm{g} / \mathrm{m}^{3}$ ) foi significativamente superior ao Ponto 2 (MP 2,5 - 20,72 $\mu \mathrm{g} / \mathrm{m}^{3} ; B C-0,185 \mu \mathrm{g} / \mathrm{m}^{3}$ ).

Os elementos $\mathrm{Si}, \mathrm{S}, \mathrm{K}, \mathrm{Ni}, \mathrm{Cu}$ e $\mathrm{Zn}$ não apresentaram diferenças significativas. Contudo, em todas as campanhas que estiveram presentes, estiveram em maior concentração para o Ponto 1 em relação aos Pontos 2 e 3. No Ponto 1, também foi identificado concentrações mais elevadas para os elementos $\mathrm{Cl}$ no mês de janeiro, $\mathrm{Pb}$ em setembro e para o $\mathrm{Si}$ nos meses de maio e setembro. 
Os elementos $\mathrm{Al}, \mathrm{Ca}, \mathrm{Ti}$, apresentaram concentração significativamente superior para o Ponto 3 no mês de maio. Dentre esses três elementos, durante o mês de maio, o Ca apresentou a maior concentração $\left(11,675 \mu \mathrm{g} / \mathrm{m}^{3}\right)$, sendo seguido pelo Al $\left(0,254 \mu \mathrm{g} / \mathrm{m}^{3}\right)$ e pelo $\mathrm{Ti}\left(0,032 \mu \mathrm{g} / \mathrm{m}^{3}\right)$.

Os elementos $\mathrm{Mg}, \mathrm{Si}, \mathrm{P}, \mathrm{Cl}, \mathrm{V}, \mathrm{Cr}, \mathrm{Mn}, \mathrm{Fe}, \mathrm{Se}, \mathrm{Br}$ e $\mathrm{Pb}$ não apresentaram diferenças significativas nas concentrações para os diferentes pontos nas diferentes campanhas.

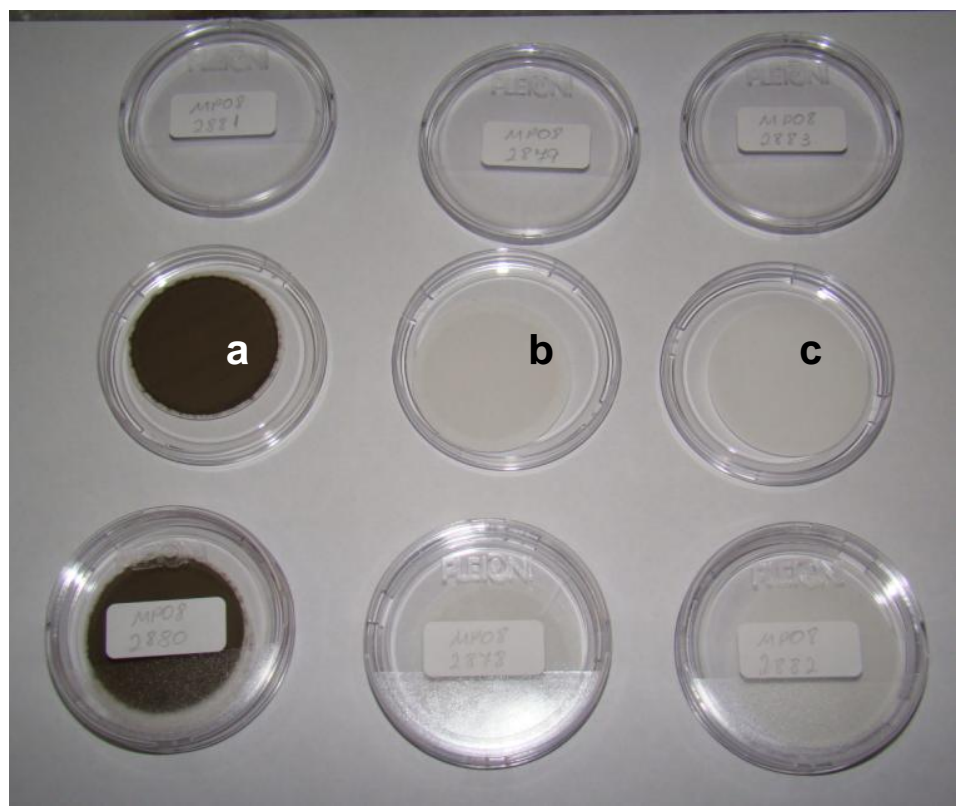

Figura 16. Filtros de policarbonato usado no Mini-sampler após campanha de exposição nos três pontos teste. a - Corresponde a comunidade do Amarelão (Ponto 1); b - Corresponde ao ponto UFRN (Ponto 3); c - Corresponde a Faz. Sta. Luzia (Ponto 2).

Os resultados da análise elementar foram submetidos à Correlação de Spearman para verificar o grau de relacionamento entre as variáveis estudadas. De forma geral, em todos os três pontos foram detectadas várias correlações entre diversos elementos (Tabela 4, 5 e 6). Nos três pontos estudados houve correlação positiva apenas para os elementos $\mathrm{Zn}$ e Cu. Para os Pontos 1 e 3 foram verificados correlação negativa para os elementos $\mathrm{Pb}$ e $\mathrm{Br}$. 
Tabela 3: Medições da concentração de material particulado na fração respirável (MP 2,5), Black Carbon e composição elementar para os meses de Janeiro, Maio e Setembro de 2009. A tendência central dos resultados foi apresentada como Mediana e Média, e a dispersão como Distância Interquartílica (IQR). O resultado corresponde a quantidade de elemento acumulado por área do filtro $\left(\mu \mathrm{g} / \mathrm{m}^{3}\right)$. Ponto 1 representa a Comunidade do Amarelão, Ponto 2 a Fazenda Santa Luzia e o Ponto 3 a UFRN.

\begin{tabular}{|c|c|c|c|c|c|c|c|c|c|c|}
\hline \multirow{2}{*}{\multicolumn{2}{|c|}{ Elemento }} & \multicolumn{3}{|c|}{ Janeiro - 2009} & \multicolumn{3}{|c|}{ Maio - 2009} & \multicolumn{3}{|c|}{ Setembro - 2009} \\
\hline & & \multirow{2}{*}{$\begin{array}{l}\text { Ponto } 1 \\
114,943^{\star a}\end{array}$} & \multirow{2}{*}{$\begin{array}{c}\text { Ponto } 2 \\
24,663\end{array}$} & \multirow{2}{*}{$\begin{array}{c}\text { Ponto } 3 \\
15,934\end{array}$} & \multirow{2}{*}{$\begin{array}{c}\text { Ponto } 1 \\
486^{\star * b}\end{array}$} & \multirow{2}{*}{$\begin{array}{c}\text { Ponto } 2 \\
20,72\end{array}$} & \multirow{2}{*}{$\frac{\text { Ponto } 3}{73,6^{\star c}}$} & \multirow{2}{*}{$\begin{array}{c}\text { Ponto } 1 \\
782^{*}\end{array}$} & \multirow{2}{*}{$\begin{array}{c}\text { Ponto } 2 \\
23,18\end{array}$} & \multirow{2}{*}{$\begin{array}{c}\text { Ponto } 3 \\
19,95\end{array}$} \\
\hline MP2,5 & Mediana & & & & & & & & & \\
\hline & IQR & 1302,608 & 12,847 & 4,816 & 1558 & 18,84 & 76,9 & 1624 & 19,88 & 7,98 \\
\hline & Média & 548,412 & 27,789 & 14,367 & 1022,232 & 21,112 & 83,627 & 1291,946 & 29,442 & 22,301 \\
\hline \multirow[t]{3}{*}{$\mathrm{BC}$} & Mediana & $8,323^{\star a}$ & 0,452 & 0,506 & $46,9^{* *}$ & 0,1847 & $0,863^{\star c}$ & $46,8^{*}$ & 0,6160 & 0,6115 \\
\hline & IQR & 120,414 & 0,483 & 0,296 & 78,1 & 0,141 & 0,461 & 59,4 & 0,3635 & 0,4217 \\
\hline & Média & 46,798 & 0,460 & 0,417 & 70,068 & 0,194 & 0,756 & 69,432 & 0,680 & 0,640 \\
\hline \multirow[t]{3}{*}{$M g$} & Mediana & 0,000 & 0,000 & 0,000 & 0,000 & $0,077^{b}$ & 0,428 & 0,000 & 0,000 & 0,040 \\
\hline & IQR & 0,000 & 0,000 & 0,051 & 0,000 & 0,033 & 1,358 & 0,000 & 0,000 & 0,047 \\
\hline & Média & 0,000 & 0,000 & 0,017 & 0,000 & 0,087 & 0,595 & 0,000 & 0,000 & 0,029 \\
\hline \multirow[t]{3}{*}{ Al } & Mediana & 0,095 & 0,000 & 0,000 & 0,000 & 0,085 & $0,254^{* d}$ & 0,000 & 0,000 & 0,003 \\
\hline & IQR & 0,262 & 0,074 & 0,018 & 0,000 & 0,059 & 1,368 & 0,000 & 0,011 & 0,013 \\
\hline & Média & 0,119 & 0,025 & 0,006 & 0,000 & 0,098 & 0,689 & 0,000 & 0,004 & 0,005 \\
\hline \multirow[t]{3}{*}{ Si } & Mediana & 0,105 & 0,084 & 0,039 & 2,308 & 0,266 & 2,713 & 4,040 & 0,035 & 0,045 \\
\hline & IQR & 0,693 & 0,039 & 0,115 & 19,890 & 0,227 & 7,536 & 22,591 & 0,435 & 0,103 \\
\hline & Média & 0,280 & 0,072 & 0,053 & 8,339 & 0,275 & 3,542 & 9,259 & 0,180 & 0,075 \\
\hline
\end{tabular}


Tabela 3. Continuação.

\begin{tabular}{|c|c|c|c|c|c|c|c|c|c|c|}
\hline \multirow{2}{*}{\multicolumn{2}{|c|}{ Elemento }} & \multicolumn{3}{|c|}{ Janeiro - 2009} & \multicolumn{3}{|c|}{ Maio - 2009} & \multicolumn{3}{|c|}{ Setembro - 2009} \\
\hline & & \multirow{2}{*}{$\frac{\text { Ponto } 1}{0,005}$} & \multirow{2}{*}{$\frac{\text { Ponto } 2}{0,005}$} & \multirow{2}{*}{$\frac{\text { Ponto } 3}{0,001}$} & \multirow{2}{*}{$\begin{array}{c}\text { Ponto } 1 \\
0,000\end{array}$} & \multirow{2}{*}{$\begin{array}{c}\text { Ponto } 2 \\
0,000\end{array}$} & \multirow{2}{*}{$\begin{array}{c}\text { Ponto } 3 \\
0,000\end{array}$} & \multirow{2}{*}{$\begin{array}{c}\text { Ponto } 1 \\
0,000\end{array}$} & \multirow{2}{*}{$\frac{\text { Ponto } 2}{0,000}$} & \multirow{2}{*}{$\frac{\text { Ponto } 3}{0,000}$} \\
\hline $\mathbf{P}$ & Mediana & & & & & & & & & \\
\hline & IQR & 0,015 & 0,006 & 0,004 & 0,001 & 0,001 & 0,000 & 0,122 & 0,010 & 0,000 \\
\hline & Média & 0,007 & 0,004 & 0,002 & 0,000 & 0,000 & 0,000 & 0,041 & 0,003 & 0,000 \\
\hline \multirow[t]{3}{*}{$\mathbf{S}$} & Mediana & 0,545 & 0,104 & 0,176 & 0,543 & 0,073 & 0,336 & 0,439 & 0,180 & 0,160 \\
\hline & IQR & 2,077 & 0,070 & 0,297 & 0,446 & 0,044 & 0,458 & 0,357 & 0,094 & 0,164 \\
\hline & Média & 1,023 & 0,121 & 0,172 & 0,546 & 0,076 & 0,315 & 0,456 & 0,199 & 0,196 \\
\hline \multirow[t]{3}{*}{$\mathrm{Cl}$} & Mediana & 2,123 & 0,120 & 0,363 & 0,162 & 0,126 & 0,136 & 0,310 & 0,026 & 0,691 \\
\hline & IQR & 2,971 & 0,707 & 0,471 & 0,686 & 0,187 & 0,187 & 1,168 & 0,009 & 0,681 \\
\hline & Média & 1,786 & 0,302 & 0,282 & 0,283 & 0,104 & 0,157 & 0,608 & 0,023 & 0,773 \\
\hline \multirow[t]{3}{*}{ K } & Mediana & $1,031^{*}$ & 0,136 & 0,065 & 1,061 & 0,109 & 0,520 & 1,467 & 0,173 & 0,114 \\
\hline & IQR & 2,257 & 0,243 & 0,095 & 3,475 & 0,244 & 2,227 & 3,680 & 0,116 & 0,096 \\
\hline & Média & 1,427 & 0,200 & 0,067 & 2,048 & 0,124 & 0,944 & 2,349 & 0,186 & 0,137 \\
\hline \multirow[t]{3}{*}{$\mathrm{Ca}$} & Mediana & 0,193 & 0,088 & 0,029 & 0,124 & 0,066 & $11,675^{c}$ & 0,109 & 0,015 & 0,073 \\
\hline & IQR & 0,572 & 0,234 & 0,055 & 0,296 & 0,081 & 42,805 & 0,144 & 0,007 & 0,074 \\
\hline & Média & 0,310 & 0,114 & 0,028 & 0,180 & 0,056 & 18,291 & 0,115 & 0,015 & 0,093 \\
\hline \multirow[t]{3}{*}{$\mathrm{Ti}$} & Mediana & 0,000 & 0,000 & 0,000 & 0,000 & 0,000 & $0,032^{\star}$ & 0,006 & 0,001 & 0,003 \\
\hline & IQR & 0,012 & 0,001 & 0,002 & 0,000 & 0,000 & 0,113 & 0,009 & 0,003 & 0,003 \\
\hline & Média & 0,004 & 0,001 & 0,001 & 0,000 & 0,000 & 0,051 & 0,005 & 0,001 & 0,003 \\
\hline
\end{tabular}


Tabela 3. Continuação.

\begin{tabular}{|c|c|c|c|c|c|c|c|c|c|c|}
\hline \multirow{2}{*}{\multicolumn{2}{|c|}{ Elemento }} & \multicolumn{3}{|c|}{ Janeiro - 2009} & \multicolumn{3}{|c|}{ Maio - 2009} & \multicolumn{3}{|c|}{ Setembro - 2009} \\
\hline & & \multirow{2}{*}{$\begin{array}{c}\text { Ponto } 1 \\
0,000\end{array}$} & \multirow{2}{*}{$\frac{\text { Ponto } 2}{0,000}$} & \multirow{2}{*}{$\frac{\text { Ponto } 3}{0,000}$} & \multirow{2}{*}{$\begin{array}{c}\text { Ponto } 1 \\
0,000\end{array}$} & \multirow{2}{*}{$\begin{array}{c}\text { Ponto } 2 \\
0,000\end{array}$} & \multirow{2}{*}{$\begin{array}{c}\text { Ponto } 3 \\
0,001\end{array}$} & \multirow{2}{*}{$\begin{array}{c}\text { Ponto } 1 \\
0,000\end{array}$} & \multirow{2}{*}{$\frac{\text { Ponto } 2}{0,000}$} & \multirow{2}{*}{$\frac{\text { Ponto } 3}{0,000}$} \\
\hline $\mathbf{V}$ & Mediana & & & & & & & & & \\
\hline & IQR & 0,002 & 0,000 & 0,000 & 0,001 & 0,000 & 0,010 & 0,000 & 0,001 & 0,001 \\
\hline & Média & 0,001 & 0,000 & 0,000 & 0,000 & 0,000 & 0,004 & 0,000 & 0,000 & 0,000 \\
\hline \multirow[t]{3}{*}{$\mathrm{Cr}$} & Mediana & 0,000 & 0,000 & 0,000 & 0,000 & 0,000 & 0,000 & 0,008 & 0,001 & 0,000 \\
\hline & IQR & 0,060 & 0,000 & 0,001 & 0,000 & 0,003 & 0,001 & 0,097 & 0,004 & 0,001 \\
\hline & Média & 0,020 & 0,000 & 0,000 & 0,000 & 0,001 & 0,000 & 0,035 & 0,001 & 0,000 \\
\hline \multirow[t]{3}{*}{ Mn } & Mediana & 0,006 & 0,003 & 0,001 & 0,000 & 0,000 & 0,005 & 0,000 & 0,000 & 0,000 \\
\hline & IQR & 0,018 & 0,004 & 0,001 & 0,006 & 0,002 & 0,008 & 0,000 & 0,000 & 0,001 \\
\hline & Média & 0,008 & 0,003 & 0,001 & 0,002 & 0,001 & 0,004 & 0,000 & 0,000 & 0,001 \\
\hline \multirow[t]{3}{*}{$\mathrm{Fe}$} & Mediana & 0,207 & 0,007 & 0,008 & 0,017 & 0,015 & 0,368 & 0,004 & 0,000 & 0,020 \\
\hline & IQR & 0,282 & 0,013 & 0,032 & 0,046 & 0,009 & 1,117 & 0,006 & 0,005 & 0,082 \\
\hline & Média & 0,163 & 0,007 & 0,013 & 0,026 & 0,013 & 0,511 & 0,003 & 0,002 & 0,037 \\
\hline \multirow[t]{3}{*}{$\mathrm{Ni}$} & Mediana & $0,020^{*}$ & 0,003 & 0,000 & 0,033 & 0,004 & 0,003 & 0,022 & 0,001 & 0,002 \\
\hline & IQR & 0,016 & 0,006 & 0,000 & 0,027 & 0,004 & 0,007 & 0,019 & 0,001 & 0,003 \\
\hline & Média & 0,016 & 0,004 & 0,000 & 0,041 & 0,005 & 0,004 & 0,027 & 0,001 & 0,002 \\
\hline \multirow[t]{3}{*}{$\mathrm{Cu}$} & Mediana & 0,045 & 0,007 & 0,000 & $0,323^{a}$ & 0,023 & 0,017 & 0,000 & 0,000 & 0,003 \\
\hline & IQR & 0,026 & 0,037 & 0,000 & 0,539 & 0,042 & 0,026 & 0,000 & 0,002 & 0,029 \\
\hline & Média & 0,039 & 0,015 & 0,000 & 0,325 & 0,022 & 0,014 & 0,000 & 0,001 & 0,011 \\
\hline
\end{tabular}


Tabela 3. Continuação.

\begin{tabular}{|c|c|c|c|c|c|c|c|c|c|c|}
\hline \multirow{2}{*}{\multicolumn{2}{|c|}{ Elemento }} & \multicolumn{3}{|c|}{ Janeiro - 2009} & \multicolumn{3}{|c|}{ Maio - 2009} & \multicolumn{3}{|c|}{ Setembro - 2009} \\
\hline & & \multirow{2}{*}{$\frac{\text { Ponto } 1}{0,044^{*}}$} & \multirow{2}{*}{$\frac{\text { Ponto } 2}{0,003}$} & \multirow{2}{*}{$\frac{\text { Ponto } 3}{0,000}$} & \multirow{2}{*}{$\begin{array}{c}\text { Ponto } 1 \\
0,220^{a}\end{array}$} & \multirow{2}{*}{$\begin{array}{c}\text { Ponto } 2 \\
0,019\end{array}$} & \multirow{2}{*}{$\begin{array}{c}\text { Ponto } 3 \\
0,018\end{array}$} & \multirow{2}{*}{$\begin{array}{c}\text { Ponto } 1 \\
0,000\end{array}$} & \multirow{2}{*}{$\begin{array}{c}\text { Ponto } 2 \\
0,000\end{array}$} & \multirow{2}{*}{$\frac{\text { Ponto } 3}{0,000}$} \\
\hline $\mathbf{Z n}$ & Mediana & & & & & & & & & \\
\hline & IQR & 0,041 & 0,049 & 0,000 & 0,365 & 0,030 & 0,033 & 0,000 & 0,005 & 0,028 \\
\hline & Média & 0,036 & 0,019 & 0,000 & 0,208 & 0,017 & 0,017 & 0,000 & 0,002 & 0,010 \\
\hline \multirow[t]{3}{*}{$\mathrm{Se}$} & Mediana & 0,004 & 0,000 & 0,000 & 0,000 & 0,000 & 0,000 & 0,000 & 0,000 & 0,000 \\
\hline & IQR & 0,011 & 0,001 & 0,001 & 0,001 & 0,001 & 0,000 & 0,005 & 0,002 & 0,002 \\
\hline & Média & 0,005 & 0,000 & 0,000 & 0,000 & 0,000 & 0,000 & 0,002 & 0,001 & 0,001 \\
\hline \multirow[t]{3}{*}{$\mathrm{Br}$} & Mediana & 0,000 & 0,000 & 0,000 & 0,013 & 0,005 & 0,000 & 0,000 & 0,003 & 0,004 \\
\hline & IQR & 0,012 & 0,000 & 0,001 & 0,038 & 0,006 & 0,000 & 0,000 & 0,003 & 0,007 \\
\hline & Média & 0,004 & 0,000 & 0,000 & 0,017 & 0,005 & 0,000 & 0,000 & 0,003 & 0,004 \\
\hline \multirow[t]{3}{*}{$\mathbf{P b}$} & Mediana & 0,009 & 0,002 & 0,002 & 0,000 & 0,000 & 0,002 & 0,023 & 0,000 & 0,000 \\
\hline & IQR & 0,019 & 0,002 & 0,001 & 0,000 & 0,002 & 0,004 & 0,098 & 0,000 & 0,000 \\
\hline & Média & 0,009 & 0,001 & 0,001 & 0,000 & 0,001 & 0,003 & 0,040 & 0,000 & 0,000 \\
\hline
\end{tabular}

* e** Correspondem aos resultados que diferiram significativamente entre os três pontos em uma mesma campanha de exposição $(\mathrm{P} \leq 0,05)$.

"a" e "b" Correspondem aos resultados que diferiram significativamente para o Ponto 1 entre as três campanhas de exposição $(P \leq 0,05)$.

"c" Corresponde ao resultado que diferiu significativamente para o Ponto 2 entre as três campanhas de exposição (P $\leq 0,05)$.

"d" Corresponde ao valor que diferiu significativamente para o Ponto 3 entre as três campanhas de exposição $(P \leq 0,05)$. 
Tabela 4. Correlação de Spearman para os elementos acumulados nos filtros de policarbonato pelo Mini-sampler no Ponto 1.

\begin{tabular}{|c|c|c|c|c|c|c|c|c|c|c|c|c|c|c|c|c|c|c|}
\hline & $\mathbf{M g}$ & Al & $\mathbf{S i}$ & $\mathbf{P}$ & $\mathbf{S}$ & $\mathrm{Cl}$ & K & $\mathrm{Ca}$ & $\mathrm{Ti}$ & $\mathbf{V}$ & $\mathrm{Cr}$ & $\mathrm{Mn}$ & $\mathrm{Fe}$ & $\mathbf{N i}$ & $\mathrm{Cu}$ & $\mathrm{Zn}$ & $\mathrm{Se}$ & $\mathrm{Br}$ \\
\hline Mg & * & & & & & & & & & & & & & & & & & \\
\hline Al & * & 1 & & & & & & & & & & & & & & & & \\
\hline $\mathbf{S i}$ & * & $-0,70$ & 1 & & & & & & & & & & & & & & & \\
\hline $\mathbf{P}$ & * & 0,05 & 0,00 & 1 & & & & & & & & & & & & & & \\
\hline$S$ & * & $-0,37$ & 0,38 & 0,60 & 1 & & & & & & & & & & & & & \\
\hline $\mathrm{Cl}$ & * & $-0,07$ & $-0,18$ & 0,84 & 0,50 & 1 & & & & & & & & & & & & \\
\hline K & * & $-0,27$ & 0,30 & 0,71 & 0,30 & 0,65 & 1 & & & & & & & & & & & \\
\hline $\mathrm{Ca}$ & * & $-0,05$ & $-0,03$ & 0,58 & 0,83 & 0,42 & 0,02 & 1 & & & & & & & & & & \\
\hline $\mathrm{Ti}$ & * & $-0,37$ & 0,35 & 0,35 & 0,49 & 0,57 & 0,26 & 0,15 & 1 & & & & & & & & & \\
\hline V & * & $-0,37$ & 0,23 & $-0,11$ & 0,56 & $-0,06$ & $-0,38$ & 0,50 & 0,24 & 1 & & & & & & & & \\
\hline $\mathrm{Cr}$ & * & 0,12 & 0,22 & 0,62 & 0,24 & 0,49 & 0,68 & 0,01 & 0,35 & $-0,48$ & 1 & & & & & & & \\
\hline Mn & * & 0,01 & $-0,30$ & 0,27 & 0,33 & 0,47 & 0,03 & 0,31 & 0,24 & 0,60 & $-0,11$ & 1 & & & & & & \\
\hline $\mathrm{Fe}$ & * & $-0,03$ & $-0,33$ & 0,20 & 0,45 & 0,34 & 0,03 & 0,49 & $-0,09$ & 0,56 & $-0,16$ & 0,79 & 1 & & & & & \\
\hline $\mathrm{Ni}$ & * & $-0,30$ & 0,78 & $-0,09$ & 0,15 & $-0,48$ & 0,22 & $-0,10$ & $-0,23$ & 0,06 & 0,15 & $-0,40$ & $-0,27$ & 1 & & & & \\
\hline $\mathrm{Cu}$ & * & $-0,02$ & 0,03 & $-0,13$ & 0,29 & $-0,29$ & $-0,15$ & 0,32 & $-0,48$ & 0,57 & $-0,45$ & 0,34 & 0,63 & 0,39 & 1 & & & \\
\hline $\mathrm{Zn}$ & * & $-0,02$ & 0,00 & $-0,09$ & 0,42 & $-0,19$ & $-0,29$ & 0,46 & $-0,26$ & 0,80 & $-0,45$ & 0,56 & 0,73 & 0,22 & 0,93 & 1 & & \\
\hline $\mathrm{Se}$ & * & $-0,05$ & 0,02 & 0,76 & 0,58 & 0,73 & 0,40 & 0,51 & 0,51 & 0,36 & 0,40 & 0,73 & 0,41 & $-0,20$ & $-0,04$ & 0,19 & 1 & \\
\hline $\mathrm{Br}$ & * & $-0,45$ & 0,24 & $-0,40$ & 0,27 & $-0,38$ & $-0,51$ & 0,29 & $-0,11$ & 0,86 & $-0,59$ & 0,38 & 0,46 & 0,16 & 0,56 & 0,71 & 0,06 & 1 \\
\hline $\mathrm{Pb}$ & * & 0,33 & 0,16 & 0,40 & $-0,02$ & 0,27 & 0,46 & $-0,22$ & 0,36 & $-0,59$ & 0,90 & $-0,28$ & $-0,47$ & 0,13 & $-0,59$ & $-0,59$ & 0,20 & $-0,72$ \\
\hline
\end{tabular}

Coeficiente de correlação acima de 0,7 está destacado em negrito. 
Tabela 5. Correlação de Spearman para os elementos acumulados nos filtros de policarbonato pelo Mini-sampler no Ponto 2.

\begin{tabular}{|c|c|c|c|c|c|c|c|c|c|c|c|c|c|c|c|c|c|c|}
\hline & $\mathbf{M g}$ & Al & Si & $\mathbf{P}$ & S & $\mathrm{Cl}$ & $\mathrm{K}$ & $\mathrm{Ca}$ & $\mathrm{Ti}$ & $\mathbf{V}$ & $\mathrm{Cr}$ & Mn & $\mathrm{Fe}$ & $\mathbf{N i}$ & $\mathrm{Cu}$ & $\mathrm{Zn}$ & $\mathrm{Se}$ & $\mathrm{Br}$ \\
\hline $\mathrm{Mg}$ & 1 & & & & & & & & & & & & & & & & & \\
\hline Al & 0,86 & 1 & & & & & & & & & & & & & & & & \\
\hline $\mathrm{Si}$ & 0,52 & 0,42 & 1 & & & & & & & & & & & & & & & \\
\hline $\mathbf{P}$ & $-0,29$ & 0,07 & $-0,46$ & 1 & & & & & & & & & & & & & & \\
\hline $\mathbf{S}$ & $-0,77$ & $-0,51$ & $-0,33$ & 0,42 & 1 & & & & & & & & & & & & & \\
\hline $\mathrm{Cl}$ & $-0,05$ & 0,01 & 0,30 & $-0,15$ & $-0,27$ & 1 & & & & & & & & & & & & \\
\hline $\mathbf{K}$ & $-0,38$ & $-0,19$ & $-0,03$ & 0,20 & 0,20 & 0,40 & 1 & & & & & & & & & & & \\
\hline $\mathrm{Ca}$ & 0,01 & 0,21 & 0,37 & $-0,16$ & $-0,13$ & 0,77 & 0,70 & 1 & & & & & & & & & & \\
\hline $\mathrm{Ti}$ & $-0,48$ & $-0,52$ & 0,07 & $-0,13$ & 0,43 & 0,04 & 0,60 & 0,29 & 1 & & & & & & & & & \\
\hline V & $-0,11$ & 0,01 & $-0,47$ & 0,13 & 0,42 & $-0,20$ & $-0,12$ & $-0,16$ & $-0,02$ & 1 & & & & & & & & \\
\hline $\mathrm{Cr}$ & 0,00 & 0,09 & 0,43 & 0,16 & 0,34 & $-0,14$ & 0,52 & 0,20 & 0,52 & $-0,02$ & 1 & & & & & & & \\
\hline Mn & $-0,23$ & $-0,21$ & $-0,24$ & 0,28 & $-0,18$ & 0,16 & $-0,15$ & $-0,13$ & $-0,20$ & $-0,59$ & $-0,59$ & 1 & & & & & & \\
\hline $\mathrm{Fe}$ & 0,76 & 0,86 & 0,59 & 0,15 & $-0,48$ & 0,02 & $-0,31$ & 0,05 & $-0,56$ & $-0,37$ & 0,11 & 0,09 & 1 & & & & & \\
\hline $\mathrm{Ni}$ & 0,52 & 0,34 & 0,15 & $-0,31$ & $-0,87$ & 0,62 & 0,10 & 0,42 & $-0,29$ & $-0,22$ & $-0,38$ & 0,16 & 0,21 & 1 & & & & \\
\hline $\mathrm{Cu}$ & 0,37 & 0,22 & 0,04 & $-0,59$ & $-0,56$ & 0,14 & $-0,35$ & 0,16 & $-0,19$ & $-0,10$ & $-0,70$ & 0,27 & 0,05 & 0,49 & 1 & & & \\
\hline $\mathrm{Zn}$ & 0,20 & $-0,03$ & $-0,12$ & $-0,59$ & $-0,56$ & 0,24 & $-0,32$ & 0,09 & $-0,18$ & $-0,08$ & $-0,81$ & 0,35 & $-0,16$ & 0,58 & 0,94 & 1 & & \\
\hline $\mathrm{Se}$ & 0,01 & $-0,33$ & $-0,09$ & $-0,72$ & $-0,24$ & $-0,35$ & $-0,13$ & $-0,20$ & 0,16 & $-0,13$ & $-0,23$ & $-0,10$ & $-0,42$ & 0,06 & 0,47 & 0,52 & 1 & \\
\hline $\mathrm{Br}$ & 0,61 & 0,35 & 0,37 & $-0,69$ & $-0,30$ & $-0,23$ & $-0,47$ & $-0,15$ & $-0,14$ & 0,39 & 0,04 & $-0,69$ & 0,12 & 0,12 & 0,34 & 0,25 & 0,40 & 1 \\
\hline $\mathrm{Pb}$ & $-0,02$ & $-0,17$ & $-0,01$ & $-0,21$ & $-0,29$ & 0,68 & $-0,11$ & 0,19 & 0,00 & 0,11 & $-0,48$ & 0,26 & $-0,20$ & 0,57 & 0,33 & 0,51 & $-0,20$ & 0,02 \\
\hline
\end{tabular}

Coeficiente de correlação acima de 0,7 está destacado em negrito. 
Tabela 6. Correlação de Spearman para os elementos acumulados nos filtros de policarbonato pelo Mini-sampler no Ponto 3.

\begin{tabular}{|c|c|c|c|c|c|c|c|c|c|c|c|c|c|c|c|c|c|c|}
\hline & $\mathbf{M g}$ & $\mathbf{A l}$ & $\mathrm{Si}$ & $\mathbf{P}$ & $\mathbf{S}$ & $\mathrm{Cl}$ & $\mathrm{K}$ & $\mathbf{C a}$ & $\mathrm{Ti}$ & $\mathbf{V}$ & $\mathrm{Cr}$ & Mn & $\mathrm{Fe}$ & $\mathbf{N i}$ & $\mathrm{Cu}$ & $\mathrm{Zn}$ & $\mathrm{Se}$ & $\mathrm{Br}$ \\
\hline $\mathbf{M g}$ & 1 & & & & & & & & & & & & & & & & & \\
\hline Al & 0,51 & 1 & & & & & & & & & & & & & & & & \\
\hline Si & 0,41 & 0,54 & 1 & & & & & & & & & & & & & & & \\
\hline $\mathbf{P}$ & 0,00 & $-0,16$ & $-0,64$ & 1 & & & & & & & & & & & & & & \\
\hline$S$ & 0,41 & 0,09 & 0,72 & $-0,46$ & 1 & & & & & & & & & & & & & \\
\hline Cl & $-0,49$ & $-0,71$ & $-0,10$ & $-0,46$ & 0,07 & 1 & & & & & & & & & & & & \\
\hline $\mathrm{K}$ & 0,45 & 0,22 & 0,70 & $-0,64$ & 0,92 & 0,13 & 1 & & & & & & & & & & & \\
\hline $\mathrm{Ca}$ & 0,47 & 0,64 & 0,92 & $-0,73$ & 0,57 & $-0,08$ & 0,68 & 1 & & & & & & & & & & \\
\hline $\mathrm{Ti}$ & 0,56 & 0,56 & 0,94 & $-0,72$ & 0,67 & $-0,02$ & 0,77 & 0,96 & 1 & & & & & & & & & \\
\hline $\mathbf{V}$ & 0,30 & 0,50 & 0,55 & $-0,37$ & 0,10 & $-0,21$ & 0,10 & 0,61 & 0,53 & 1 & & & & & & & & \\
\hline $\mathrm{Cr}$ & 0,11 & 0,28 & $-0,26$ & 0,05 & $-0,04$ & $-0,35$ & 0,13 & $-0,15$ & $-0,17$ & 0,01 & 1 & & & & & & & \\
\hline Mn & $-0,01$ & 0,45 & 0,42 & $-0,09$ & 0,13 & $-0,18$ & 0,12 & 0,28 & 0,32 & 0,46 & 0,20 & 1 & & & & & & \\
\hline $\mathrm{Fe}$ & 0,20 & 0,53 & 0,68 & $-0,64$ & 0,68 & $-0,18$ & 0,78 & 0,70 & 0,65 & 0,23 & 0,35 & 0,22 & 1 & & & & & \\
\hline $\mathrm{Ni}$ & 0,72 & 0,52 & 0,84 & $-0,54$ & 0,63 & $-0,08$ & 0,71 & 0,91 & 0,94 & 0,53 & $-0,24$ & 0,19 & 0,48 & 1 & & & & \\
\hline $\mathrm{Cu}$ & 0,12 & 0,30 & 0,53 & $-0,45$ & 0,07 & 0,29 & 0,18 & 0,58 & 0,61 & 0,61 & $-0,32$ & 0,60 & 0,02 & 0,59 & 1 & & & \\
\hline $\mathrm{Zn}$ & 0,16 & 0,47 & 0,48 & $-0,54$ & 0,15 & 0,16 & 0,37 & 0,64 & 0,60 & 0,64 & 0,16 & 0,61 & 0,35 & 0,56 & 0,84 & 1 & & \\
\hline $\mathrm{Se}$ & 0,19 & $-0,02$ & $-0,25$ & 0,34 & $-0,25$ & 0,09 & $-0,14$ & $-0,25$ & $-0,09$ & $-0,37$ & $-0,05$ & 0,23 & $-0,48$ & 0,00 & 0,30 & 0,12 & 1 & \\
\hline $\mathrm{Br}$ & $-0,37$ & $-0,50$ & $-0,37$ & $-0,05$ & $-0,13$ & 0,69 & 0,02 & $-0,20$ & $-0,22$ & $-0,36$ & $-0,12$ & $-0,23$ & $-0,24$ & $-0,14$ & 0,18 & 0,25 & 0,30 & 1 \\
\hline $\mathbf{P b}$ & 0,11 & 0,59 & 0,46 & 0,02 & 0,10 & $-0,63$ & $-0,05$ & 0,25 & 0,24 & 0,48 & 0,13 & 0,64 & 0,31 & 0,10 & 0,09 & 0,05 & $-0,26$ & $-0,85$ \\
\hline
\end{tabular}

Coeficiente de correlação acima de 0,7 está destacado em negrito. 


\subsection{Teste de Micronúcleo em T. pallida}

A fim de verificar se os poluentes oriundos da atividade da queima da castanha de caju eram capazes de provocar danos no material genético de organismos a ela expostos, foi realizado o teste de micronúcleo em tétrades de T. pallida (Figura 17). Os resultados obtidos indicaram alta freqüência de micronúcleos em todos os meses estudados para o local onde é realizado o beneficiamento da castanha de caju (Ponto 1 - Comunidade do Amarelão).

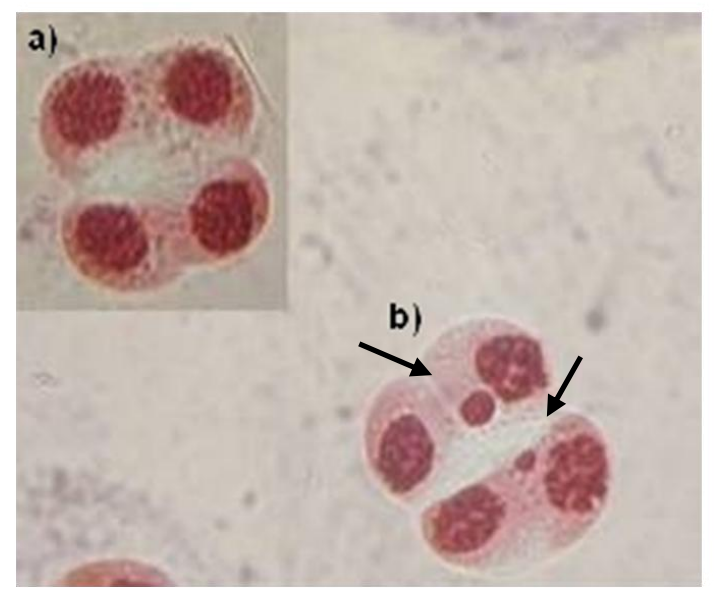

Figura 17. Microscopia óptica $(400 \mathrm{X})$ de tétrades de T. pallida corada com acetato de carmim a $2 \%$. a - Tétrade de $T$. pallida sem a presença de micronúcleos. $\mathbf{b}$ - Tétrade com dois micronúcleos (setas apontam os micronúcleos).

As médias e respectivos desvios (DP) da frequência de $\mathrm{MN}$ encontradas nos meses estudados para os diferentes pontos estão apresentadas na Tabela 7. A análise estatística indicou que em todos os meses estudados o número de MN encontrado para o Ponto 1 foi significativamente superior aos Pontos 2 e 3 . Com relação ao Ponto 3, exceto no mês de maio, a freqüência de $\mathrm{MN}$ encontradas foi um pouco superior aos resultados verificados para o Ponto 2, e significativamente inferior aos valores encontrados para o Ponto 1. No mês de Maio de 2009, o Ponto 3 apresentou a maior freqüência de MN para esse ponto, se aproximando mais do Ponto 1, do que do Ponto 2. Os resultados obtidos estão apresentados na Tabela 7 e Figura 18.

As freqüências de MN verificadas para o Ponto 1 foram: Set/08 - 5,5 \pm 1,7 \%; Jan/09 - 8,5 \pm 2,3 \%; Mai/09 - 5,4 $\pm 2,0 \%$ e Set/09 - 5,8 $\pm 2,8 \%$. Para o 
Ponto 2, os resultados foram: Set/08 - 2,2 $\pm 1,2 \%$; Jan/09 - 1,3 $\pm 0,6 \%$; Mai/09 $1,5 \pm 1,1 \%$ e Set/09 - 1,3 \pm 0,8 \%. Para o Ponto 3: Set/08 - 2,5 $\pm 0,8 \%$; Jan/09 $2,0 \pm 0,4 \%$;Mai/09 - 4,0 $\pm 2,4 \%$ e Set/09 - 2,7 $\pm 0,9 \%$.

Tabela 7. Freqüência média e desvio padrão do número de micronúcleos encontrados em tétrades de $T$. pallida no biomonitoramento realizado nos meses de setembro (2008), Janeiro, Maio e Setembro (2009). Os dados são relativos ao número de micronúcleos encontrados em cada 100 tétrades analisadas. Ponto 1 representa a Comunidade do Amarelão, Ponto 2 a Fazenda Santa Luzia e o Ponto 3 a UFRN.

\begin{tabular}{lcccc}
\hline Local & Setembro - 08 & Janeiro - 09 & Maio - 09 & Setembro - 09 \\
\hline Ponto 1 & $5,5^{\star} \pm 1,7$ & $8,5^{\star} \pm 2,3$ & $5,4^{\star} \pm 2,0$ & $5,8^{\star \star} \pm 2,8$ \\
Ponto 2 & $2,2 \pm 1,2$ & $1,3 \pm 0,6$ & $1,5 \pm 1,1$ & $1,3 \pm 0,8$ \\
Ponto 3 & $2,5 \pm 0,8$ & $2,0 \pm 0,4$ & $4,0^{\star} \pm 2,4$ & $2,7^{\star} \pm 0,9$
\end{tabular}

${ }^{*} \mathrm{e}{ }^{* *}$ Correspondem aos resultados que diferiram significativamente $(\mathrm{P} \leq 0,05)$. 

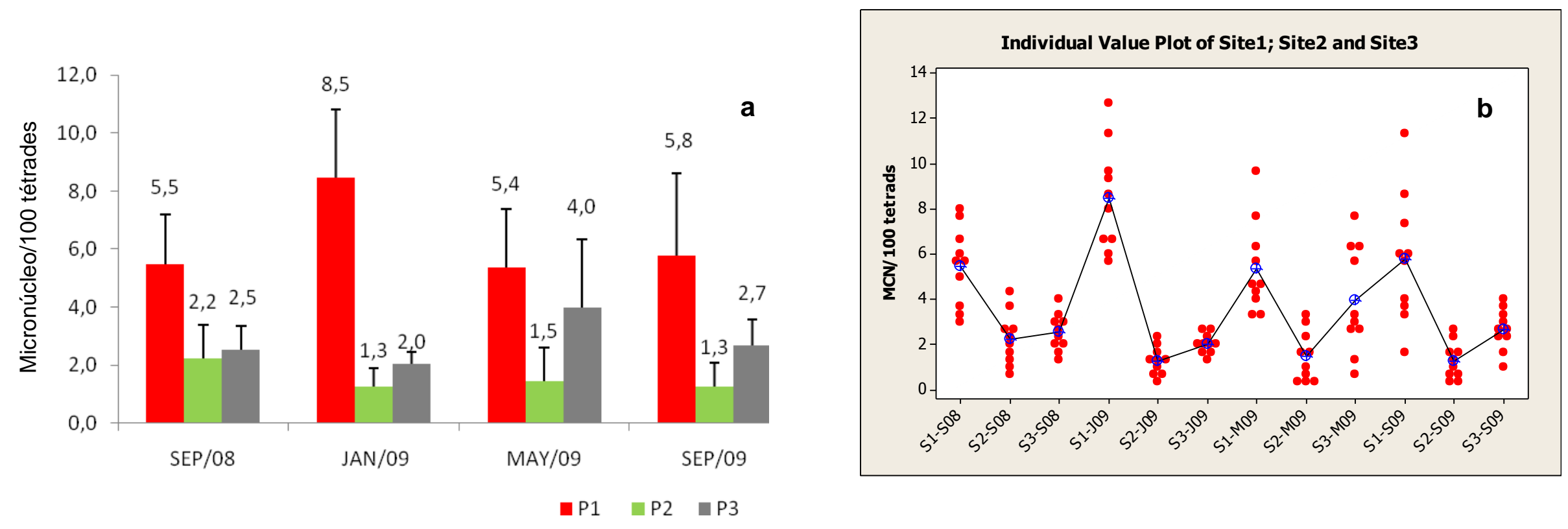

Figura 18: a - Gráfico apresentando a freqüência média e desvio padrão do número de micronúcleos encontrados em tétrades de T. pallida em cada 100 tétrades analisadas durante o biomonitoramento. P1 representa a Comunidade do Amarelão; P2 a Fazenda Sta. Luzia; P3 a UFRN. b - Gráfico de valores individuais: Cada ponto vermelho indica um valor individual encontrado na amostra e o ponto azul a média dos resultados em cada amostra. S1, S2 e S3 representam o P1, P2 e P3 respectivamente. 


\subsection{Teste de micronúcleo em mucosa oral de humanos}

\subsubsection{Características dos participantes}

Para a análise de mucosa oral foram selecionadas 90 pessoas voluntárias subdivididas em 45 trabalhadores da atividade do beneficiamento da castanha de caju e 45 pertencentes ao grupo controle. As principais características dos participantes da pesquisa estão sumarizadas na Tabela 8. O grupo teste era composto por 25 homens e 20 mulheres, enquanto o grupo controle por 21 homens e 24 mulheres. A idade média dos trabalhadores da castanha e do grupo controle eram 28,93 $\pm 10,48$ anos e 26,07 \pm 9,03 anos, respectivamente. Os trabalhadores já exerciam a atividade do beneficiamento da castanha por 12,83 anos, e o grupo controle não tinha qualquer relação com a atividade. A jornada de trabalho dos beneficiadores excedia a 10 horas diárias (10,86 $\pm 2,6$ horas), enquanto o grupo controle apresentou média de 6,4 $\pm 1,4$ horas. $O$ consumo de bebidas alcoólicas foi similar entre o grupo teste e o controle (25 e 24 pessoas respectivamente). Entre os 8 casos de câncer relatado pelos participantes da comunidade do amarelão, 2 casos foram de câncer de pulmão, 1 de mama, 1 de cabeça, 1 do tipo leucemia, 1 de próstata e 2 casos não souberam especificar o tipo. Para o grupo controle, dos 25 casos relatados, o câncer de mama foi o mais freqüente (5 casos), seguido por próstata (4 casos), pele e leucemia (3 casos cada) e em último lugar, os casos de câncer de pulmão, tireóide, garganta, estômago e não souberam especificar o tipo ( 2 casos cada).

Tabela 8. Principais características e número de $M N$ encontrados nos trabalhadores do beneficiamento da castanha de caju e indivíduos pertencentes ao grupo controle.

\begin{tabular}{lcc}
\hline & $\begin{array}{c}\text { Trabalhadores da } \\
\text { castanha de caju }\end{array}$ & Controle \\
\hline $\mathrm{N}^{\circ}$ de Indivíduos avaliados & 45 & 45 \\
$\mathrm{~N}^{\circ}$ de Homens & 25 & 21 \\
$\mathrm{~N}^{\circ}$ de Mulheres & 20 & 24 \\
Idade em anos (Média \pm DP) & $28,93 \pm 10,48$ & $26,07 \pm 9,03$ \\
Anos de exposição & 12,83 & - \\
\hline
\end{tabular}


Tabela 8. Continuação.

\begin{tabular}{|c|c|c|}
\hline & $\begin{array}{l}\text { Trabalhadores da } \\
\text { castanha de caju }\end{array}$ & Controle \\
\hline Jornada diária de trabalho em horas & $10,86 \pm 2,6$ & $6,4 \pm 1,4$ \\
\hline Fumante & 6 & 3 \\
\hline Consumo de Bebidas alcoólicas & 25 & 24 \\
\hline$N^{\circ}$ de filhos & 2,6 & 0,4 \\
\hline Câncer na família & 8 & 25 \\
\hline $\begin{array}{l}N^{\circ} \text { de abortos espontâneo / } N^{\circ} \text { de } \\
\text { mulheres que abortaram }\end{array}$ & $5 / 4$ & $2 / 2$ \\
\hline $\begin{array}{l}\text { Realizou tratamento odontológico } \\
\text { na última semana }\end{array}$ & - & - \\
\hline $\mathrm{N}^{\circ}$ de $\mathrm{MN}$ em 1000 células & $4,6^{\star} \pm 3,48$ & $2,56 \pm 1,87$ \\
\hline $\begin{array}{l}N^{\circ} \text { de MN em } 1000 \text { células } \\
\text { (Usuários de Tabaco) }\end{array}$ & $5,3^{*} \pm 3,72$ & $2,0 \pm 0,82$ \\
\hline $\begin{array}{l}N^{\circ} \text { de MN em } 1000 \text { células } \\
\text { (Usuários de bebidas alcoólicas) }\end{array}$ & $4,92^{*} \pm 3,89$ & $2,91 \pm 2,15$ \\
\hline
\end{tabular}

\subsubsection{Número de micronúcleo em mucosa oral humana}

No intuito de verificar se os trabalhadores expostos à atividade da queima da castanha de caju apresentavam aumento no número de micronúcleos em relação à população não exposta, foi realizado análise de micronúcleo em mucosa oral dos beneficiadores. Os resultados obtidos indicaram que as pessoas que atuam na atividade do beneficiamento da castanha apresentaram aumento significativo $(P \leq 0,05)$ na freqüência de micronúcleos. O grupo exposto apresentou média de 4,6 \pm 3,48 micronúcleos em cada 1000 células analisadas, enquanto o grupo não exposto apresentou média de 2,56 \pm 1,87 micronúcleos em 1000 células (Tabela 8). Não houve diferenças significativas para o número de MN obtidos dentro do grupo exposto e do grupo controle devido ao efeito do uso de cigarros ou bebidas. Nas figuras 19 e 20 verifica-se imagens das células analisadas e os resultados obtidos respectivamente. 


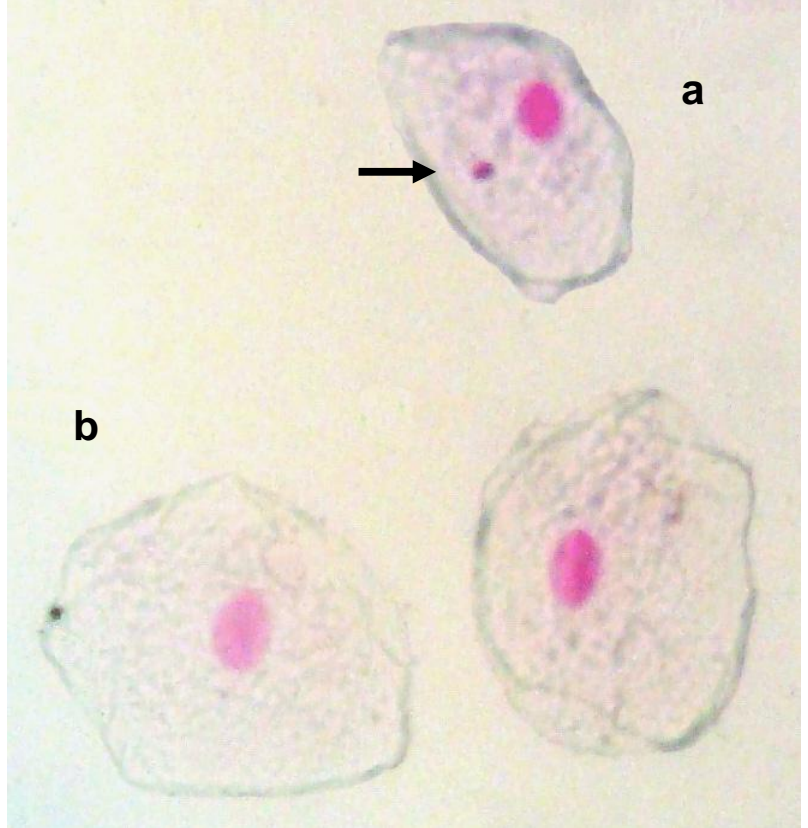

Figura 19. Microscopia óptica $(400 \mathrm{X})$ de células esfoliadas de mucosa oral humana coradas com reativo de Shiff. a - Seta indica a presença de micronúcleo; b - células esfoliadas sem a presença de micronúcleos. 


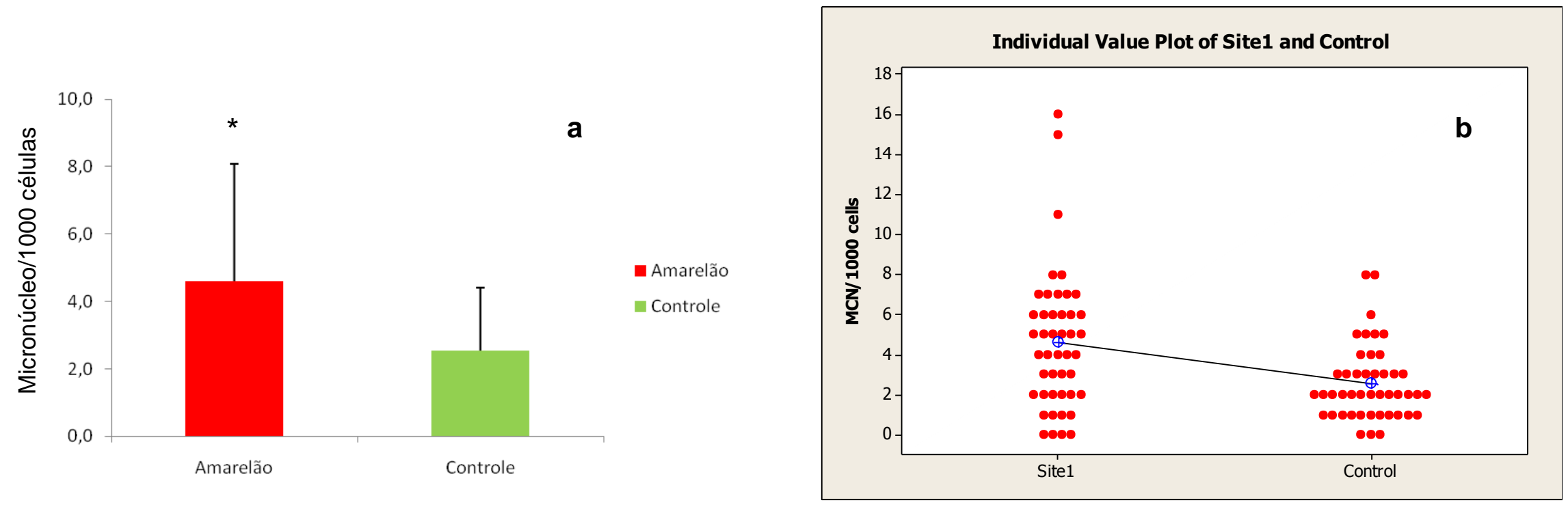

Figura 20. a - Gráfico apresentando a freqüência média e desvio padrão do número de micronúcleos encontrados em células de mucosa oral em cada 1000 células analisadas nos indivíduos pertencentes ao grupo teste e ao grupo controle. b - Gráfico de valores individuais: Cada ponto vermelho indica um valor individual encontrado na amostra; o ponto azul indica a média dos resultados em cada amostra. Site 1 e Control representam o grupo teste e o grupo controle respectivamente.

* Diferença estatisticamente significativa para $\mathrm{P} \leq 0,05$. 


\section{DISCUSSÃO}

Considerando que a qualidade do ar é um fator limitante para a saúde dos organismos e desse modo é fundamental para a qualidade de vida das pessoas, os resultados apresentados no presente trabalho indicaram que a atividade do beneficiamento artesanal da castanha de caju apresenta um grave efeito negativo na saúde ambiental. Os resultados indicaram uma clara necessidade de uma política pública de gestão dos contaminantes produzidos pelo beneficiamento artesanal da castanha de caju, além de uma demanda de ordem social para com a comunidade do Amarelão. Além dos trabalhadores que atuam na atividade, outros membros que não atuam diretamente no beneficiamento da castanha também podem sofrer influência dos poluentes. A atividade é desenvolvida no entorno das residências, e desse modo, a dispersão dos poluentes na maioria dos casos incide nas casas da comunidade, pois não existe planejamento algum entre a execução da atividade e a disposição das residências. Portanto, devido à falta de planejamento habitacional até mesmo grupos mais frágeis, como idosos e crianças na primeira infância, também recebem influencia da atividade. No presente estudo, as concentrações de alguns componentes identificados e o marcador biológico estudado ( $\mathrm{MN}$ ) indicaram alta concentração de alguns poluentes e que esses poluentes atuam de forma negativa nos organismos.

Para melhor entender quais os principais componentes presentes nos três pontos estudados foram realizadas medições de vários componentes: $\mathrm{O}_{3}, \mathrm{NO}_{2}$, MP (1,0 ųm; 2,5 ųm; 10 ųm), BC, Mg, Al, Si, P, S, Cl, K, Ca, Ti, V, Cr, Mn, Fe, Ni, $\mathrm{Cu}, \mathrm{Zn}, \mathrm{Se}, \mathrm{Br}$, e $\mathrm{Pb}$. A presença de alguns componentes em altas concentrações pode atuar como importantes indicadores de exposição a poluentes ambientais.

$\mathrm{O}_{3}$ e $\circ \mathrm{NO}_{2}$ são importantes indicadores de poluição atmosférica, os quais são monitorados comumente em áreas urbanas. De forma geral, os resultados obtidos indicaram que os dois elementos estiveram em concentrações inferiores aos limites estabelecidos pelo CONAMA e pela OMS nos três pontos estudados (CONAMA 003/1990; WHO 2005a).

$\mathrm{O} \mathrm{O}_{3}$ apresentou concentrações que diferiram estatisticamente entre os três pontos nas campanhas do mês de janeiro e setembro. Nessas duas campanhas, 
a maior concentração registrada foi para o Ponto 2. No mês de Setembro, o Ponto 1 apresentou a segunda maior concentração, também apresentando resultados superiores aos dois outros meses estudados. No mês de Maio, foram verificadas as menores concentrações do $\mathrm{O}_{3}$ para os três pontos relativos às três campanhas, não sendo identificadas diferenças estatísticas entre os diferentes locais.

$\mathrm{O}_{3}$ é um poluente secundário formado pelas reações fotoquímicas que envolvem $\mathrm{NO}_{2}, \mathrm{O}_{2}$ e radiação solar. Além das concentrações de $\mathrm{O}_{3}$ sofrerem alterações devido ao efeito da oxidação fotoquímica, existe o efeito do transporte horizontal devido a ação dos ventos que levam $0 \mathrm{O}_{3}$ do local onde é produzido para locais distantes (Dueñas et al. 2002; Pires et al. 2008). No presente estudo, as maiores concentrações do poluente foram identificadas no Ponto 2, e esse ponto localiza-se em um ambiente rural, onde não ocorre atividades urbanas ou industriais. Contudo, esse local dista aproximadamente $80 \mathrm{~km}$ da cidade de Natal, capital do estado do $\mathrm{RN}$, onde fica o maior centro urbano de toda a região e onde se localiza o Ponto 3.

Nos meses em que foram registradas as mais altas concentrações de $\mathrm{O}_{3}$, também foram registrados os menores índices pluviométricos, e maiores velocidades médias dos ventos entre as campanhas segundo dados do Instituto Nacional de Meteorologia (INMET) (ANEXO II). Além disso, o sentido predominante dos ventos em todos os meses estudados foi Sudeste (SE), ou seja, os ventos passam primeiro na cidade de Natal e em seguida no Ponto 2. Levando-se em consideração que a concentração de $\mathrm{O}_{3}$ pode ser influenciada pela precipitação, velocidade e sentido dos ventos, é provável que as maiores concentrações de $\mathrm{O}_{3}$ identificadas para o Ponto 2 tenha sido influenciada pela atividade urbana desenvolvida na cidade de Natal. Os poluentes produzidos pelas diversas atividades urbanas podem atingir outros locais carreados pelo sentido e velocidade dos ventos. Os poluentes produzidos pelas atividades urbanas altera a atmosfera local principalmente por NOx, e esses poluentes gerados podem atingir outros locais, e inclusive aumentar a concentração de $\mathrm{O}_{3}$ a partir da foto-oxidação do $\mathrm{NO}_{2}$. Além disso, nas regiões próximas as fontes de emissões de NOx (centros urbanos), onde existem abundancia de $\mathrm{NO}, \mathrm{o} \mathrm{O}_{3}$ é removido e como resultado a concentração de $\mathrm{O}_{3}$ é freqüentemente baixa em áreas urbanas, e maiores nas 
regiões suburbanas e zonas rurais adjacentes. No Ponto 1, os baixos índices de $\mathrm{O}_{3}$ detectados para os meses de janeiro e maio provavelmente foi influenciado principalmente pela intensa queima de castanha de caju, pois seria esperado que em condições normais (sem a atividade do beneficiamento da castanha), as concentrações fossem semelhantes aos resultados encontradas para o Ponto 2. O Ponto 2 dista aproximadamente $13 \mathrm{Km}$ do Ponto 1, e o Ponto 1 está localizado posteriormente ao Ponto 2 (Seguindo o sentido dos ventos - SE). Essa localização indica que os ventos que passam pelo Ponto 2 provavelmente chegariam no Ponto 1. Além disso, na região não existe elementos ambientais (relevo) ou da atividade humana (indústrias ou área de intensa atividade urbana) que diferenciariam os dois pontos. Portanto, a hipótese provável é que a queima de matéria orgânica presente no Ponto 1 leva a fortes alterações atmosféricas locais as quais podem reduzir as concentrações de $\mathrm{O}_{3}$ principalmente pela presença de NOx, o qual tem capacidade de interagir com $\circ \mathrm{O}_{3}$ e elevar as concentrações de $\mathrm{NO}_{2}$. Contudo, para confirmar essa hipótese era esperado que, simultaneamente, fosse encontrada maior variação na concentração de $\mathrm{NO}_{2}$ para o Ponto 1, pois de forma geral a presença de $\mathrm{NO}_{2}$ e $\mathrm{O}_{3}$ são inversamente proporcionais (Clapp \& Jenkin 2001), e essa variação na concentração de $\mathrm{NO}_{2}$ só ocorreu de forma sucinta. No entanto, mesmo de forma sucinta, a correlação de Espearman realizada para cada ponto no presente estudo entre $\mathrm{o}_{3} \mathrm{O}_{3} \mathrm{NO}_{2}$ indicou a ocorrência de correlações negativas entre a concentração dos dois elementos.

A presença de $\mathrm{NO}_{2}$ está relacionada principalmente a combustão. Em todos os meses estudados apenas em janeiro houve diferenças significativas com relação à concentração de $\mathrm{NO}_{2}$ entre os pontos estudados, sendo a maior concentração para o Ponto 2. Entre os meses estudados, as maiores concentrações foram registradas para o mês de maio. Como a produção de $\mathrm{NO}_{2}$ pode ser dada de forma direta, ou após a transformação do NO em NO2 por processos fotoquímicos, é provável que a menor velocidade dos ventos registrados para o mês de maio tenha favorecido a uma menor dispersão do poluente, e desse modo a identificação das maiores concentrações registrada. De forma geral, os resultados de $\mathrm{O}_{3}$ e $\mathrm{NO}_{2}$ demandam estudos complementares, com 
o objetivo de melhor entender as variações nas concentrações dos elementos principalmente para os Pontos 1 e 2.

Os resultados obtidos a partir das medições de MP realizadas na comunidade do Amarelão com o medidor portátil "DUSTTRAK"M Aerossol Monitor" indicou que os trabalhadores envolvidos no beneficiamento da castanha de caju estão expostos a uma concentração de MP que excede o nível de exposição estabelecido pela Resolução № 03 de 28 de junho de 1990 do Conselho Nacional de Meio Ambiente - CONAMA (de 500 $\mu \mathrm{g} / \mathrm{m} 3$ para partículas inaláveis, ou seja, partículas com diâmetro menor que 10,0 $\mu \mathrm{m}$ ) (CONAMA 003/1990), assim como as orientações de referencia da Organização Mundial de Saúde (WHO 2005b). Os níveis de material particulado são tão elevados, que superam o nível definido como "estado de emergência" definido na resolução brasileira.

As avaliações realizadas nos meses de Janeiro, Maio e Setembro de 2009, com o Mini-sampler confirmaram os resultados previamente obtidos e anteriormente apresentados com o "DUSTTRAK ${ }^{\text {TM }}$ Aerossol Monitor". Os resultados indicaram altas concentrações de MP para o Ponto 1 e baixos para os Pontos 2 e 3. Em todas as campanhas a concentração de MP para o Ponto 1 foi significativamente superior aos Pontos 2 e 3 . Nessas campanhas foi observado que a concentrações dos poluentes apresentaram altas variações (ver IQR Tabela 3), e essas variações podiam ocorrer diariamente devido principalmente a intensidade e variação no sentido dos ventos. Esse resultado foi devido ao caráter artesanal da atividade, a qual é desenvolvida com pouco planejamento de segurança pessoal, onde o principal elemento que diminui a exposição à fumaça são as condições de velocidade, freqüência e sentido dos ventos. Contudo, mesmo havendo essas variações diárias que inclusive eram influenciadas pelas variações anuais do clima, foi observado em todos os períodos estudados (estação seca, chuvosa e intermediária) que diariamente ocorriam momentos de forte incidência de MP sobre os beneficiadores, especialmente durante a madrugada, momento em que é dado o início da atividade e é comum a baixa intensidade dos ventos. Além disso, a diminuição da intensidade dos poluentes sobre os beneficiadores não implica em completa eliminação momentânea dos 
efeitos da atividade, pois a fumaça que deixa de incidir sobre os beneficiadores, ao se dispersar, atinge as residências do entorno.

O valor médio de MP obtido nas três campanhas para o Ponto 1 (Jan $548,412 \mu \mathrm{g} / \mathrm{m}^{3}$; Mai - 1022,232 $\mu \mathrm{g} / \mathrm{m}^{3}$; Set - 1291,946 $\mu \mathrm{g} / \mathrm{m}^{3}$ ) foi superior a, no mínimo, 20 vezes o valor máximo obtido para a atividade da queima da cana de açúcar no Sudeste do Brasil (Lara et al. 2005). Recentemente See e Balasubramanian estudaram o efeito de diferentes formas de cozer alimentos, e os resultados apresentados pelos pesquisadores demonstraram que existe maior exposição humana ao MP 2,5 ao cozinhar do que durante eventos de exposição ambiental (Götschi et al. 2005; See \& Balasubramanian 2008; Feng et al. 2009). Os resultados apresentados indicaram maiores índices de MP 2,5 por preparações de frituras, as quais são tradicionais na culinária Chinesa, Indiana e Malaia. Esse estudo apresentou resultados máximos na produção de MP 2,5 próximo da metade das menores médias encontradas no presente trabalho. $\mathrm{E}$ nesse caso os pesquisadores alertaram para uma necessidade de melhoria na ventilação das cozinhas, com o objetivo de minimizar o efeito negativo do MP na saúde dos trabalhadores (See \& Balasubramanian 2008).

Em todo mundo, principalmente em países pobres ou em desenvolvimento mais de 2 bilhões de pessoas dependem de biomassa como principal fonte de combustível para energia doméstica (Fullerton et al. 2009). Recentemente, em um estudo realizado no Malawi (África) foi avaliado o índice de MP nas residências, e os resultados obtidos foram $226 \mu \mathrm{g} / \mathrm{m}^{3}$ (Fullerton et al. 2009). Os valores obtidos no estudo desenvolvido no Malawi são muito altos, mesmo assim, são inferiores aos resultados encontrados para o beneficiamento da castanha de caju. Os maiores resultados obtidos são comparáveis apenas aos verificados em trabalhadores domésticos da área rural no Nepal, onde o MP 2,5 obteve resultados que variaram entre $136 \mu \mathrm{g} / \mathrm{m}^{3}-2610 \mu \mathrm{g} / \mathrm{m}^{3}$ (Kurmi et al. 2008).

Em regiões rurais de países ricos com inverno rigoroso, como a região norte dos EUA, é comum o uso de fornos a lenha como aquecedor residencial. Em ocasiões de inverno os indivíduos expostos podem ser submetidos a altas concentrações de MP oriundo da queima de biomassa vegetal para 0 aquecimento das residências. Nos EUA foi realizado um programa de substituição 
de fornos antigos por fornos novos e certificados pela Agencia de Poluição Ambiental Americana (EPA) no período de 2005 - 2007. Os resultados obtidos com a substituição foram níveis de redução de MP que chegaram a mais de $70 \%$, ou seja, variaram de $51,2 \mu \mathrm{g} / \mathrm{m}^{3}$ para $9,5 \mu \mathrm{g} / \mathrm{m}^{3}$ (Ward \& Noonan 2008). Ao ser comparado os resultados obtidos entre a exposição dos poluentes nos EUA com os resultados obtidos para a comunidade do Amarelão, ficam evidentes as diferenças entre os níveis de exposição dos dois locais, onde as exposições do beneficiamento da castanha são significativamente superiores. Além disso, nos EUA os fornos de aquecimento são usados em ocasiões anuais de inverno, enquanto no beneficiamento da castanha são eventos de exposição diária que ocorrem durante todo o ano.

Ao comparar os resultados do Ponto 1 com 21 locais em 20 diferentes cidades de toda a Europa, os menores resultados médios obtidos para o MP 2,5 no presente estudo excedem em, no mínimo, 13 vezes ao pior nível encontrado na Europa (Götschi et al. 2005). Os valores são tão altos que as menores médias encontradas no presente estudo superam em, no mínimo, 5 vezes ao comparar com os maiores valores por estação do ano encontrados na cidade de Xangai na China (Feng et al. 2009).

A comparação de resultados ocupacionais e ambientais indica que em ambos os casos os níveis de produção de MP na atividade do beneficiamento da castanha de caju são extremos, e, além disso, a ausência de fiscalização ou gestão na atividade demonstra uma maior fragilidade devido à falta de conhecimento associado a queima da castanha de caju. Os valores de emissão de MP se aproximam apenas em eventos de exposição em ambiente doméstico comuns em países pobres, no qual a queima de matéria orgânica funciona como combustível na preparação de alimentos.

Os Pontos 2 e 3 apresentaram baixos índices de MP, exceto para 0 Ponto 3 no mês de maio. O Ponto 3 localiza-se em um prédio da UFRN em um ambiente urbano da cidade de Natal. No Mês de maio ocorreu uma grande reforma no prédio próximo a esse ponto. Desse modo, a elevação na concentração do MP foi atribuída à poeira proveniente das obras realizadas no referido prédio. Nesse ponto, os elementos encontrados na análise elementar em 
altas concentrações durante o mês de maio ( $\mathrm{Al}, \mathrm{Ca}$ e $\mathrm{Ti}$ ) indicaram a presença de componentes comuns na construção civil (Querol et al. 2001). Os valores obtidos para o Ponto 2 em todas as campanhas foi adequado, indicando baixa concentração de MP para a região rural usada como controle. A baixa concentração de MP no Ponto 3 indicou que, mesmo em condições urbanas, a Zona Sul da cidade do Natal, apresenta baixos índices de material particulado em suspensão no ar (Tabela 1), exceto para o episódio do mês de maio.

A composição do MP pode variar significativamente no tempo e no espaço, primariamente devido a variações na fonte de emissão, condições meteorológicas, processos físicos e reações químicas, além de eventos de combustão, tráfego de veículos, ocorrência de emissões industriais e fontes naturais como a poeira influenciada pelo vento e pelo spray do mar (Götschi et al. 2005). No Ponto 1 os elementos Si, S, K, Ni, Cu, Zn, Cl, Si e Pb foram encontrados em uma, duas ou todas as campanhas em concentrações superior aos demais pontos. A presença de metais de transição como o $\mathrm{Cu}$ e o $\mathrm{Zn}$ e do metal $\mathrm{Pb}$ contribuem para a capacidade oxidativa do MP e desse modo são componentes importantes indicativos de potencial genotóxico da amostra (McNeilly et al. 2004; Di Pietro et al. 2009; Nawrot et al. 2009). Além da queima da castanha, as condições de trabalho encontradas no local favorecem a alterações na composição do MP. No local do beneficiamento, a atividade é realizada em palhoças montadas sobre a terra desprovida de qualquer revestimento. Desse modo, além da elevação de elementos oriundos da queima da castanha, componentes como o $\mathrm{Si}, \mathrm{S}, \mathrm{K}$ e o $\mathrm{Si}$ presentes na crosta terrestre podem aparecer em níveis elevados devido principalmente à poeira gerada pela ação do vento e pelo constante fluxo de pessoas e animais no mesmo ambiente em que se desenvolve a atividade.

Um importante componente pertencente ao MP é o $B C$. O $B C$ é formado pela combustão incompleta de biomassa ou de combustíveis fósseis (Höller et al. 2002). Aumento da concentração desse elemento pode alterar o balanço térmico da atmosfera pelo aumento da temperatura devido à absorção da radiação incidente (Simoneit 2002). O BC também está associado com o aumento da pressão sanguínea e com o aumento da ocorrência de infarto do miocárdio (Zanobetti \& Schwartz 2006; Irina Mordukhovich 2009). De forma semelhante ao 
MP, a concentração de $B C$ do Ponto 1 foi significativamente superior as concentrações dos Pontos 2 e 3. Para o Ponto 1 houve uma correlação positiva de 0,66 entre o MP e $B C$. Esse resultado confirma a observação de que o alto volume de castanha de caju queimada na comunidade aumenta de forma significativa a quantidade de compostos orgânicos na fração 2,5 $\mu \mathrm{m}$ dispersa na atmosfera. Com relação ao Ponto 3 , no mês de maio também houve maior concentração de $B C$, assim como aumento na concentração do MP. Mesmo com esse aumento, a concentração foi muito inferior ao Ponto 1 , se aproximando mais dos resultados obtidos para o Ponto 2. Os resultados de $B C$ encontrados para o Ponto 1 são extremos. O valor médio obtido nas três campanhas é superior a, no mínimo, 4 vezes ao valor máximo obtido em um ano de estudo na atividade da queima da cana de açúcar no Sudeste do Brasil (Lara et al. 2005).

Em conjunto, os dados contendo os indicadores de exposição aos poluentes atmosféricos demonstraram que a atividade do beneficiamento artesanal da castanha de caju possui capacidade significativa de alterar a composição dos poluentes atmosféricos. Os resultados sugerem ainda que, dependendo da capacidade de dispersão de cada poluente é possível que esses elementos interfiram na composição atmosférica de regiões adjacentes a Comunidade do Amarelão. Sendo interessante inclusive detectar qual o raio de influencia da atividade.

Levando-se em consideração que a identificação dos componentes presentes em cada ponto não pode ser considerada unicamente em avaliações ambientais, ensaios contendo organismos são importantes marcadores biológicos que demonstram o efeito real da interação entre os diferentes componentes do meio abiótico sobre os organismos. Nesse contexto, o presente estudo utilizou a freqüência de $\mathrm{MN}$ em tétrades de plantas $T$. pallida e em células esfoliadas de mucosa oral dos trabalhadores como marcadores biológicos do efeito da exposição de organismos aos poluentes da atividade do beneficiamento da castanha de caju. O ensaio de MN indica a presença de componentes mutagênicos com capacidade de atuar como agentes promotores de clastogenicidade e/ou aneugenicidade. Os dados da literatura demonstram que 0 teste de micronúcleo possui alta sensibilidade, desde que a exposição aos agentes poluentes ocorra por um período mínimo suficiente para causar o dano, 
pois é necessária a ocorrência de mitose, possibilitando a eventual formação de micronúcleo (Fenech 2000).

Os resultados obtidos com a $T$. pallida indicaram que em todos os meses avaliados o número de $\mathrm{MN}$ identificados para o Ponto 1 foi significativamente superior ao número de $\mathrm{MN}$ do Ponto 2. Além disso, exceto para o mês de maio/09, todos os resultados também foram superiores aqueles encontrados para o Ponto 3. As plantas têm sido amplamente utilizadas em estudos de genotoxicidade, demonstrado alta sensibilidade e praticidade no seu uso como organismo biomonitor. Diversos trabalhos utilizando o teste de micronúcleo em T. pallida têm apresentado resultados positivos na detecção de compostos químicos genotóxicos (Carreras et al. 2009).

Os dados obtidos para o Ponto 1 são similares aos encontrados num estudo utilizando o clone de Tradescantia BNL- 4430 em uma indústria química de PVC na Coréia do Sul, onde foi detectado o potencial mutagênico associado a compostos orgânicos voláteis (Kim et al. 2003). Os resultados obtidos na freqüência de $\mathrm{MN}$ em $T$. pallida para o Ponto 1 também são próximos dos verificados em um estudo realizado na atmosfera de Congonhas em São Paulo durante episódios agudos de poluição (Guimarães et al. 2000).

Para o Ponto 3, no mês de maio foi detectado aumento significativo no número de $\mathrm{MN}$ com relação ao Ponto 2. Esse resultado foi devido às atividades de construção civil realizadas próximo a esse ponto. No mesmo período, além do aumento do número de MN também foi verificado aumento no MP 2,5 e no $B C$. $A$ análise elementar do MP indicou a presença de aumento significativo para o metal de transição Ti. A presença do Ti representa um importante fator que pode ter contribuído para o aumento do número de $\mathrm{MN}$ detectado nesse ponto, tendo em vista a possibilidade de danos oxidativos no DNA relacionados com a presença do metal de transição nessa campanha (McNeilly et al. 2004; Di Pietro et al. 2009; Nawrot et al. 2009).

Os resultados obtidos para o Ponto 2 indicaram que a freqüência média de micronúcleos encontrada para esse ponto, foi menor do que à encontrada em outros estudos que utilizaram regiões situadas em zonas rurais como comparativas para testes utilizando a $T$. pallida para avaliações de poluentes 
atmosféricos (Guimarães et al. 2000; Carreras et al. 2006; Prajapati \& Tripathi 2008). Esse resultado indica também que em condições normais, a região onde ocorre o beneficiamento da castanha não apresenta poluentes naturais em concentrações capazes de elevar a freqüência de $\mathrm{MN}$ no biomonitor vegetal, tendo em vista que as condições naturais dos Pontos 1 e 2 são semelhantes.

Para verificar se os poluentes oriundos do beneficiamento da castanha de caju eram capazes de interagirem com material genético das células humanas, foi realizado o teste de $\mathrm{MN}$ em mucosa oral em trabalhadores que atuam diretamente com o beneficiamento da castanha de caju. Os resultados obtidos com os 45 indivíduos voluntários participantes do estudo indicaram que a atividade eleva de forma significativa a freqüência de $\mathrm{MN}$ em mucosa oral humana. Este resultado corroborou com os resultados obtidos com o biomonitor vegetal, demonstrando que ambas as técnicas foram sensíveis na detecção de compostos com efeitos genotóxicos.

Os resultados encontrados para o $\mathrm{MN}$ em células de mucosa oral foram bastante variáveis sendo verificados valores diversos em ambos os grupos, expostos a atividade e aqueles não expostos. O comportamento do biomonitor vegetal foi diferente, onde variações menores foram apresentadas. Essa diferença entre as técnicas quanto à variedade dos resultados dentro do próprio biomonitor pode ser justificada pela baixa variedade genética presente nas plantas, pois todas foram originadas por propagação assexuada, sendo todas as plantas possuidoras do mesmo material genético, diferente dos voluntários participantes do presente estudo. Em estudos realizados com humanos é impossível o alto grau de homogeneidade genética que é possível com plantas. De forma geral, estudos tanto in vitro quanto in vivo de organismos expostos a mutágenos ambientais apresentam alta variação quanto à resposta aos componentes mutagênicos. As variações são atribuídas aos complicados processos que envolvem a expressão do biomarcador e as diferenças individuais significativas relativas à susceptibilidade e resistência de cada indivíduo aos diferentes agentes mutagênicos (Au 2007). Além das características genéticas individuais, hábitos de vida como $o$ ato de fumar, deficiências nutricionais, infecções crônicas, idade, entre outras pode aumentar o efeito da exposição em certos indivíduos (Au 2007). 
Recentemente um estudo realizado em trabalhadores e/ou moradores próximos a uma refinaria de petróleo no Rio Grande do Sul (Brasil), indicou que os poluentes atmosféricos (PM 10) coletados nessa região demonstraram potencial genotóxico em testes com bactérias e linfócitos, mas não foi detectado o potencial com células de mucosa oral (Coronas et al. 2009). Do mesmo modo, um estudo envolvendo trabalhadores rurais que entram em contato com pesticida também na região Sul do Brasil, apresentou genotoxicidade para o teste de cometa, mas não resultou em aumento na freqüência de $M N$ em células de mucosa oral (Remor et al. 2009). Contudo, um estudo realizado com fumantes de tabaco em cachimbos especiais (Waterpipe), indicou resultados positivos quanto a presença de MN (El-Setouhy et al. 2008).

Os resultados obtidos com o teste de $\mathrm{MN}$, tanto no modelo vegetal quanto no modelo humano utilizados no presente trabalho, indicaram que os componentes presentes na atmosfera da comunidade do Amarelão estão causando danos no DNA e que esses danos não estão sendo totalmente corrigidos pelo sistema de reparo das células, pois a freqüência de micronúcleos foi significativamente superior aos valores encontrados para os organismos usados como controle. Em conjunto, os testes de genotoxicidade indicaram um significativo potencial mutagênico na atividade do beneficiamento artesanal da castanha de caju, representando um problema ocupacional grave, pois a contaminação por compostos genotóxicos pode afetar negativamente a qualidade de vida das pessoas e dos demais organismos, os quais convivem diariamente com os poluentes oriundos da atividade.

Os resultados obtidos com a avaliação quantitativa e qualitativa do material particulado, associado às análises de genotoxicidade, indicaram clara e urgente, necessidade de uma política pública de gestão dos contaminantes liberados na atividade do beneficiamento da castanha de caju, assim como um acompanhamento mais cuidadoso da saúde dos moradores da comunidade do Amarelão. A forma como atividade é desenvolvida é pouco conhecida pela sociedade. Além de a comunidade ter difícil acesso, o qual ocorre por estradas de terra, os grupos familiares não apresentam integração, cooperativas ou lideranças políticas locais. Essa exclusão social tem como conseqüência uma pouca representatividade política, promovendo se não o agravamento, a ausência de 
qualquer melhoria nas condições de trabalho. A comunidade apresenta gerações que vivem exclusivamente dessa atividade, e mesmo assim, o beneficiamento continua a ser desenvolvido da mesma forma com o passar dos anos.

O presente estudo identificou a presença de altas concentrações de MP na comunidade do Amarelão, provocada pela queima da castanha de caju. Adicionalmente, foi observada toxicidade genética em $T$. pallida e em mucosa oral de indivíduos expostos. Diante da importância da qualidade do ar que respiramos e da grande importância social e econômica da castanha de caju para milhares de famílias que atuam no processamento artesanal da castanha de caju em todo o mundo, se faz necessário a elaboração de um programa periódico de avaliação da qualidade do ar, levando em conta não somente os parâmetros químicos, mas também analises de mutagenicidade. A rentabilidade conhecida da atividade, e a importância especialmente para comunidades pobres tornam urgente a demanda por apoio do estado aos beneficiadores. Os resultados contidos neste estudo possibilitaram a identificação de um problema ocupacional grave. Para que ocorra mudanças faz-se necessário uma atuação significativa dos gestores públicos para que promovam a organização de associações e financiem projetos de minifábricas com sistemas de exaustão e eliminação de poluentes efetivo. A saúde dos trabalhadores é fundamental para a sustentabilidade da atividade e atualmente os resultados obtidos indicaram uma atividade inconcebível de ser praticada sem controle da incidência de poluentes nos trabalhadores. 


\section{CONCLUSÕES}

Em conjunto, os resultados de $\mathrm{NO}_{2}$ e $\mathrm{O}_{3}$ apresentaram baixas concentrações, e que essas concentrações foram provavelmente influenciadas pelas condições ambientais de índice pluviométrico, intensidade e sentido dos ventos. Contudo, os resultados demandam estudos complementares, com o objetivo de determinar qual o mecanismo de dispersão dos poluentes para elucidar o raio de ação da atividade do beneficiamento da castanha de caju, assim como a influencia da atividade urbana da cidade de Natal em regiões adjacentes.

Os resultados obtidos com dois diferentes amostradores ativos de MP indicaram concentrações muito altas da emissão de MP pela atividade do beneficiamento artesanal da castanha de caju em todas as campanhas realizadas. Os resultados obtidos para esse ponto são superiores aos limites máximos estabelecidos pelo CONAMA e pela OMS. Em contraste, os resultados obtidos para a região controle e para a região urbana da cidade de Natal apresentou baixas concentrações de MP. No entanto, apenas na campanha do mês de maio, foi detectado na região urbana de Natal maior índice de MP, e essa elevação foi atribuída a atividades de construção civil.

Os resultados obtidos indicaram que na comunidade do Amarelão havia presença de $B C$ em altas concentrações durante todo o período estudado.

A composição elementar do MP indicou que na comunidade do Amarelão alguns elementos ocorreram em maior concentração, e que esses elementos se caracterizavam pela presença de metais de transição e de elementos minerais comuns na crosta terrestre. Para o Ponto 2 não houve variações nos elementos encontrados. Para o Ponto 3 na campanha do mês de maio foi comum elementos presentes em materiais usados na construção civil.

Os resultados obtidos a partir dos testes de genotoxicidade de micronúcleo em tétrades de T. pallida indicaram potencial genotóxico da fumaça gerada pela atividade do beneficiamento artesanal da queima da castanha de caju. 
Os resultados de micronúcleo em células esfoliadas de mucosa oral em humanos corroboraram com os resultados obtidos com as plantas, onde foi verificado aumento do número de $\mathrm{MN}$ em indivíduos expostos a atividade.

A genotoxicidade encontrada foi devido principalmente aos altos índices de MP e a natureza química desses poluentes encontrados no Ponto 1 em todo o período experimental. Para o Ponto 3 o efeito mutagênico identificado para o mês de maio foi atribuída também a concentração e natureza química do MP na referida campanha.

A gravidade dos índices de poluição atmosférica encontradas no presente estudo indica que trabalhadores do processo de beneficiamento artesanal da castanha de caju, como por exemplo, os da comunidade do Amarelão, podem representar um modelo para estudos de efeito de exposição aguda e crônica a poluentes atmosféricos gerados pela pirólise de matéria orgânica.

Os resultados do presente estudo indicam a necessidade de uma ação conjunta da sociedade e poder público em propor uma alternativa viável para essa comunidade, diminuindo os efeitos lesivos da atividade da queima da castanha nas pessoas. Além disso, demonstra a necessidade do desenvolvimento de pesquisas que possam identificar problemas e auxiliar tanto a sociedade quanto aos órgãos públicos a tomar decisões voltadas para melhoria da qualidade de vida das pessoas, especialmente comunidades pobres e com pouco amparo social.

Sendo assim, a atividade da maneira como é realizada atualmente, é caracterizada como um problema ocupacional grave com sérios riscos a saúde dos trabalhadores envolvidos no processo. 


\section{PERSPECTIVAS E RECOMENDAÇÕES}

Devido à grande importância da atividade do beneficiamento da castanha de caju, os resultados obtidos no presente trabalho demonstram a necessidade de estudos contínuos que permitam auxiliar no melhoramento das condições de trabalho na atividade.

Os resultados ora obtidos, indicaram a presença de contaminantes genotóxicos, bem como concentração de material particulado muito superior ao permitido pela legislação recomendando a necessidade de uma intervenção emergencial dos gestores públicos na atividade.

Faz-se necessário ainda descobrir qual o mecanismo de mutagênese produzido pela atividade, assim como verificar a hipótese dos danos oxidativos sugerido pela identificação da composição elementar de metais de transição na comunidade.

Recomenda-se a realização de um estudo epidemiológico sobre a ocorrência de câncer e alterações cardiovasculares, sugeridas pela alta incidência de MP e $B C$ na comunidade. Os dados de internamentos e mortalidade disponíveis no DATASUS 2008 para a cidade de João Câmara demonstram uma provável subnotificaçaõ dos casos devido principalmente à fragilidade do sistema hospitalar local (DATASUS, 2008).

As informações geradas devem ser cuidadosamente analisadas e as atitudes tomadas pelos gestores têm que visar em primeiro lugar à saúde e o bem estar dos trabalhadores. Ações que visem simplesmente o fim da atividade podem causar prejuízos ainda maiores às comunidades, levando até mesmo a marginalização dos trabalhadores.

Medidas como o afastamento remunerado de mulheres grávidas deve ser sugerido imediatamente para que a saúde da mãe e filho sejam asseguradas.

A comunidade do Amarelão deve ser vista como uma comunidade que apresenta uma vocação consolidada a uma importante atividade geradora de emprego e renda. Sendo a castanha de caju um produto valioso no mercado 
local, regional, nacional e internacional. Os recursos gerados pela atividade devem ser mais bem aproveitados para que os recursos provenientes da atividade possibilitem uma melhor qualidade de vida para as famílias envolvidas com o processo.

A deficiência quanto ao sistema de saúde e a falta de escola na comunidade é um dos maiores entraves no desenvolvimento desta comunidade. A falta de escola é certamente um dos principais agentes que contribuem para a falta de melhoria da atividade, onde os jovens que conseguem no máximo se alfabetizarem, não contribuem para mudanças na atividade, pois aprendem com seus pais como executar o beneficiamento, e dessa forma constituem suas famílias, dando continuidade ao ciclo da atividade.

Portanto, diante de todos os resultados obtidos é recomendada a continuidade desse trabalho, assim como a implementação de políticas públicas que auxiliem na melhoria da qualidade de vida dos trabalhadores, para que esses aproveitem a sua vocação, gerem dinheiro e renda, mas que não condenem as futuras gerações a doenças e falta de qualidade de vida gerada pela atividade, como tem acontecido com o passar dos anos. 


\section{REFERÊNCIAS BIBLIOGRÁFICAS}

Ahmad, I., Maria, V.L., Oliveira, M., Pacheco, M. \& Santos, M.A. (2006) Oxidative stress and genotoxic effects in gill and kidney of Anguilla anguilla L. exposed to chromium with or without pre-exposure to beta-naphthoflavone. Mutation research 608, 16-28.

Akcha, F., Tanguy, A., Leday, G., Pelluhet, L., Budzinski, H. \& Chiffoleau, J.F. (2004) Measurement of DNA single-strand breaks in gill and hemolymph cells of mussels, Mytilus sp., collected on the French Atlantic Coast. Marine Environmental Research 58, 753-756.

Al-Sabti, K. \& Metcalfe, C.D. (1995) Fish micronuclei for assessing genotoxicity in water. Mutation Research/Genetic Toxicology 343, 121-135.

Allen, A.G., Cardoso, A.A. \& da Rocha, G.O. (2004) Influence of sugar cane burning on aerosol soluble ion composition in Southeastern Brazil. Atmospheric Environment 38, 5025-5038.

Alves, E.S., de Souza, S.R., Pedroso, A.N.V. \& Domingos, M. (2008) Potential of the Trad-MCN assay applied with inflorescences of Tradescantia pallida [']Purpurea' for evaluating air contamination by naphthalene. Ecotoxicology and Environmental Safety 71, 717-721.

Alvim-Ferraz, M.C.M., Sousa, S.I.V., Pereira, M.C. \& Martins, F.G. (2006) Contribution of anthropogenic pollutants to the increase of tropospheric ozone levels in the Oporto Metropolitan Area, Portugal since the 19th century. Environmental pollution (Barking, Essex : 1987) 140, 516-524.

Angerer, J., Ewers, U. \& Wilhelm, M. (2007) Human biomonitoring: State of the art. International Journal of Hygiene and Environmental Health 210, 201-228. 
Artaxo, P. \& Hansson, H.-C. (1995) Size distribution of biogenic aerosol particles from the amazon basin. Atmospheric Environment 29, 393-402.

Au, W.W. (2007) Usefulness of biomarkers in population studies: from exposure to susceptibility and to prediction of cancer. International Journal of Hygiene and Environmental Health 210, 239-246.

Barbosa, J.S., Cabral, T.M., Ferreira, D.N., Agnez-Lima, L.F. \& Batistuzzo de Medeiros, S.R. (In Press) Genotoxicity assessment in aquatic environment impacted by the presence of heavy metals. Ecotoxicology and Environmental Safety, Corrected Proof.

Batalha, J.R.F., Guimarães, E.T., Lobo, D.J.A., Lichtenfels, A.J.F.C., Deur, T., Carvalho, H.A., Alves, E.S., Domingos, M., Rodrigues, G.S. \& Saldiva, P.H.N. (1999) Exploring the clastogenic effects of air pollutants in São Paulo (Brazil) using the Tradescantia micronuclei assay. Mutation Research/Fundamental and Molecular Mechanisms of Mutagenesis 426, 229-232.

Bolognesi, C., Perrone, E., Roggieri, P., Pampanin, D.M. \& Sciutto, A. (2006) Assessment of micronuclei induction in peripheral erythrocytes of fish exposed to xenobiotics under controlled conditions. Aquatic Toxicology 78, S93-S98.

Buschini, A., Martino, A., Gustavino, B., Monfrinotti, M., Poli, P., Rossi, C., Santoro, M., Dorr, A.J.M. \& Rizzoni, M. (2004) Comet assay and micronucleus test in circulating erythrocytes of Cyprinus carpio specimens exposed in situ to lake waters treated with disinfectants for potabilization. Mutation Research/Genetic Toxicology and Environmental Mutagenesis 557, 119-129.

Carreras, H.A., Pignata, M.L. \& Saldiva, P.H.N. (2006) In situ monitoring of urban air in Córdoba, Argentina using the Tradescantia-micronucleus (Trad-MCN) bioassay. Atmospheric Environment 40, 7824-7830. 
Carreras, H.A., Rodriguez, J.H., Gonzalez, C.M., Wannaz, E.D., Garcia Ferreyra, F., Perez, C.A. \& Pignata, M.L. (2009) Assessment of the relationship between total suspended particles and the response of two biological indicators. Atmospheric Environment 43, 2944-2949.

Carslaw, D.C. (2005) Evidence of an increasing NO2/NOX emissions ratio from road traffic emissions. Atmospheric Environment 39, 4793-4802.

Carvalho-Oliveira, R., Pozo, R.M.K., Lobo, D.J.A., Lichtenfels, A.J.F.C., MartinsJunior, H.A., Bustilho, J.O.W.V., Saiki, M., Sato, I.M. \& Saldiva, P.H.N. (2005a) Diesel emissions significantly influence composition and mutagenicity of ambient particles: a case study in Sao Paulo. Environmental Research 98, 1-7.

Carvalho-Oliveira, R., Pozo, R.M.K., Lobo, D.J.A., Lichtenfels, A.J.F.C., MartinsJunior, H.A., Bustilho, J.O.W.V., Saiki, M., Sato, I.M. \& Saldiva, P.H.N. (2005b) Diesel emissions significantly influence composition and mutagenicity of ambient particles: a case study in São Paulo, Brazil. Environmental Research 98, 1-7.

Cavas, T. \& Ergene-Gozukara, S. (2005a) Genotoxicity evaluation of metronidazole using the piscine micronucleus test by acridine orange fluorescent staining. Environmental Toxicology and Pharmacology 19, 107111.

Cavas, T. \& Ergene-Gozukara, S. (2005b) Induction of micronuclei and nuclear abnormalities in Oreochromis niloticus following exposure to petroleum refinery and chromium processing plant effluents. Aquatic Toxicology 74, 264-271.

Chaloulakou, A., Mavroidis, I. \& Gavriil, I. (2008) Compliance with the annual NO2 air quality standard in Athens. Required NOx levels and expected health implications. Atmospheric Environment 42, 454-465. 
Chen, G. \& White, P.A. (2004) The mutagenic hazards of aquatic sediments: a review. Mutation Research/Reviews in Mutation Research 567, 151-225.

Clapp, L.J. \& Jenkin, M.E. (2001) Analysis of the relationship between ambient levels of $\mathrm{O} 3, \mathrm{NO} 2$ and $\mathrm{NO}$ as a function of $\mathrm{NOx}$ in the UK. Atmospheric Environment 35, 6391-6405.

Clarke, L., Edmonds, J., Krey, V., Richels, R., Rose, S. \& Tavoni, M. (2009) International climate policy architectures: Overview of the EMF 22 International Scenarios. Energy Economics 31, S64-S81.

CONAMA (003/1990) RESOLUÇÃO № 003, de 28 de junho de 1990

Cormier, S.A., Lomnicki, S., Backes, W. \& Dellinger, B. (2006) Origin and health impacts of emissions of toxic by-products and fine particles from combustion and thermal treatment of hazardous wastes and materials. Environmental Health Perspectives 114, 810-817.

Coronas, M.V., Pereira, T.S., Rocha, J.A.V., Lemos, A.T., Fachel, J.M.G., Salvadori, D.M.F. \& Vargas, V.M.F. (2009) Genetic biomonitoring of an urban population exposed to mutagenic airborne pollutants. Environment International 35, 1023-1029.

Costa, D.L. \& Dreher, K.L. (1997) Bioavailable transition metals in particulate matter mediate cardiopulmonary injury in healthy and compromised animal models. Environmental health perspectives 105, 1053-1060.

Cox, R.M. (2003) The use of passive sampling to monitor forest exposure to O3, NO2 and SO2: a review and some case studies. Environmental Pollution 126, 301-311.

Cristina dos Santos Leal, T., Crispim, V.R., Frota, M., Kelecom, A. \& Xavier da Silva, A. (2008) Use of a bioindicator system in the study of the 
mutagenetical effects in the neighborhoods of deposits of radioactive waste. Applied Radiation and Isotopes 66, 535-538.

da Silva Souza, T. \& Fontanetti, C.S. (2006) Micronucleus test and observation of nuclear alterations in erythrocytes of Nile tilapia exposed to waters affected by refinery effluent. Mutation Research/Genetic Toxicology and Environmental Mutagenesis 605, 87-93.

de Souza Lima, E., de Souza, S.R. \& Domingos, M. (2009) Sensitivity of Tradescantia pallida (Rose) Hunt. [']Purpurea' Boom to genotoxicity induced by ozone. Mutation Research/Genetic Toxicology and Environmental Mutagenesis 675, 41-45.

Dearfield, K.L., Cimino, M.C., McCarroll, N.E., Mauer, I. \& Valcovic, L.R. (2002) Genotoxicity risk assessment: a proposed classification strategy. Mutation Research/Genetic Toxicology and Environmental Mutagenesis 521, 121-135.

Delgado-Rodriguez, A., Ortíz-Marttelo, R., Graf, U., Villalobos-Pietrini, R. \& Gómez-Arroyo, S. (1995) Genotoxic activity of environmentally important polycyclic aromatic hydrocarbons and their nitro derivatives in the wing spot test of Drosophila melanogaster. Mutation Research/Genetic Toxicology 341, 235-247.

Di Pietro, A., Visalli, G., Munaò, F., Baluce, B., La Maestra, S., Primerano, P., Corigliano, F. \& De Flora, S. (2009) Oxidative damage in human epithelial alveolar cells exposed in vitro to oil fly ash transition metals. International Journal of Hygiene and Environmental Health 212, 196-208.

Dias, E.C. (2006) Condições de vida, trabalho, saúde e doença dos trabalhadores rurais no Brasil. Saúde do Trabalhador Rural - RENAST.

Diekmann, M., Waldmann, P., Schnurstein, A., Grummt, T., Braunbeck, T. \& Nagel, R. (2004) On the relevance of genotoxicity for fish populations II: 
genotoxic effects in zebrafish (Danio rerio) exposed to 4-nitroquinoline-1oxide in a complete life-cycle test. Aquatic Toxicology 68, 27-37.

Donaldson, K., Stone, V., Seaton, A. \& MacNee, W. (2001) Ambient particle inhalation and the cardiovascular system: potential mechanisms. Environmental Health Perspectives 109, 523-527.

Dueñas, C., Fernández, M.C., Cañete, S., Carretero, J. \& Liger, E. (2002) Assessment of ozone variations and meteorological effects in an urban area in the Mediterranean Coast. The Science of The Total Environment 299, 97113.

El-Setouhy, M., Loffredo, C.A., Radwan, G., Abdel Rahman, R., Mahfouz, E., Israel, E., Mohamed, M.K. \& Ayyad, S.B.A. (2008) Genotoxic effects of waterpipe smoking on the buccal mucosa cells. Mutation research $655,36-$ 40.

European-Commission (1997) Position paper on air quality: nitrogen dioxide. Working Group on Nitrogen Dioxide, EC. http://ec.europa.eu/environment/air/pdf/pp_no2.pdfS.

Fenech, M. (2000) The in vitro micronucleus technique. Mutation Research/Fundamental and Molecular Mechanisms of Mutagenesis 455, 8195.

Fenech, M.F., Bolognesi, C., Kirsch-Volders, M., Bonassi, S., Zeiger, E., Knasmuller, S. \& Holland, N. (2007) Harmonisation of the micronucleus assay in human buccal cells - a Human Micronucleus (HUMN) project (www.humn.org) initiative.

Feng, Y., Chen, Y., Guo, H., Zhi, G., Xiong, S., Li, J., Sheng, G. \& Fu, J. (2009) Characteristics of organic and elemental carbon in PM2.5 samples in Shanghai, China. Atmospheric Research 92, 434-442. 
Fernandes, J.B., Holanda, J.S.d., Chagas, M.C.M.d., Lima, J.M.P.d. \& Oliveira, J.S.F.d. (2009) Recomendações técnicas para o cultivo do cajueiro. EMPARN.

Ferreira, M.I., Domingos, M., Gomes, H.d.A., Saldiva, P.H.N. \& de Assuncao, J.V. (2007) Evaluation of mutagenic potential of contaminated atmosphere at Ibirapuera Park, Sao Paulo - SP, Brazil, using the Tradescantia stamen-hair assay. Environmental Pollution 145, 219-224.

Fullerton, D.G., Semple, S., Kalambo, F., Suseno, A., Malamba, R., Henderson, G., Ayres, J.G. \& Gordon, S.B. (2009) Biomass fuel use and indoor air pollution in homes in Malawi. Occupational and Environmental Medicine 66, 777-783.

Götschi, T., Hazenkamp-von Arx, M.E., Heinrich, J., Bono, R., Burney, P., Forsberg, B., Jarvis, D., Maldonado, J., Norbäck, D., Stern, W.B., Sunyer, J., Torén, K., Verlato, G., Villani, S. \& Künzli, N. (2005) Elemental composition and reflectance of ambient fine particles at 21 European locations. Atmospheric Environment 39, 5947-5958.

Guerra, J.G.A. (2003) Os Mendonça do Amarelão: Identidade, Memória e História oral. MNEME - REVISTA DE HUMANIDADES -ISSN 1518-3394 4.

Guimarães, E.T., Domingos, M., Alves, E.S., Caldini, N., Lobo, D.J.A., Lichtenfels, A.J.F.C. \& Saldiva, P.H.N. (2000) Detection of the genotoxicity of air pollutants in and around the city of São Paulo (Brazil) with the Tradescantiamicronucleus (Trad-MCN) assay. Environmental and Experimental Botany 44, 1-8.

Guyon, P., Graham, B., Roberts, G.C., Mayol-Bracero, O.L., Maenhaut, W., Artaxo, P. \& Andreae, M.O. (2004) Sources of optically active aerosol particles over the Amazon forest. Atmospheric Environment 38, 1039-1051. 
Hayashi, M., Tice, R.R., MacGregor, J.T., Anderson, D., Blakey, D.H., KirschVolders, M., Oleson, F.B.J., Pacchierotti, F., Romagna, F., Shimada, H., Sutou, S. \& Vannier, B. (1994) In vivo rodent erytrocyte micronúcleos assay. Mutat. Res. 312, 293 - 304.

Holland, N., Bolognesi, C., Kirsch-Volders, M., Bonassi, S., Zeiger, E., Knasmueller, S. \& Fenech, M. (2008) The micronucleus assay in human buccal cells as a tool for biomonitoring DNA damage: The HUMN project perspective on current status and knowledge gaps. Mutation Research/Reviews in Mutation Research 659, 93-108.

Höller, R., Tohno, S., Kasahara, M. \& Hitzenberger, R. (2002) Long-term characterization of carbonaceous aerosol in Uji, Japan. Atmospheric Environment 36, 1267-1275.

IBGE (2006) Produção Agrícola Municipal. INSTITUTO BRASILEIRO DE GEOGRAFIA E ESTATÍSTICA.

IBGE (2007a) Pesquisa Nacional por Amostra de Domicílios (PNAD) 2006.

IBGE (2007b) Senso Agropecuário 2006.

Irina Mordukhovich, E.W., Helen Suh, Robert Wright, David Sparrow, Pantel S. Vokonas, and Joel Schwartz (2009) Black Carbon Exposure, Oxidative Stress Genes, and Blood Pressure in a Repeated Measures Study. Environmental Health Perspectives.

James P. Lodge, J. (1988) Analysis for Atmospheric Nitrogen Dioxide (24h-H Average) Methods of Air Sampling and Analysis Editor Lewis Publishers., p:399-402.

Jenkin, M.E. (2004a) Analysis of sources and partitioning of oxidant in the UK-Part 1: the NOX-dependence of annual mean concentrations of nitrogen dioxide and ozone. Atmospheric Environment 38, 5117-5129. 
Jenkin, M.E. (2004b) Analysis of sources and partitioning of oxidant in the UK-Part 2: contributions of nitrogen dioxide emissions and background ozone at a kerbside location in London. Atmospheric Environment 38, 5131-5138.

Johansson, S.A.E. \& Campbell, J.L. (1988) PIXE A Novel Technique for Elemental Analysis. . Wiley, Chichester.

Kampa, M. \& Castanas, E. (2008) Human health effects of air pollution. Environmental Pollution 151, 362-367.

Kevekordes, S., Gebel, T., Pav, K., Edenharder, R. \& Dunkelberg, H. (1996) Genotoxicity of selected pesticides in the mouse bone-marrow micronucleus test and in the sister-chromatid exchange test with human lymphocytes in vitro. Toxicology Letters 89 , 35-42.

Kim, J.K., Shin, H.S., Lee, J.-H., Lee, J.-J. \& Lee, J.-H. (2003) Genotoxic effects of volatile organic compounds in a chemical factory as evaluated by the Tradescantia micronucleus assay and by chemical analysis. Mutation Research/Genetic Toxicology and Environmental Mutagenesis 541, 55-61.

Kornartit, C., Sokhi, R.S., Burton, M.A. \& Ravindra, K. (In press) Activity pattern and personal exposure to nitrogen dioxide in indoor and outdoor microenvironments. Environment International 36, 36-45.

Kurmi, O.P., Semple, S., Steiner, M., Henderson, G.D. \& Ayres, J.G. (2008) Particulate matter exposure during domestic work in Nepal. The Annals of occupational hygiene $52,509-517$.

Lai, H.K., Bayer-Oglesby, L., Colvile, R., Götschi, T., Jantunen, M.J., Künzli, N., Kulinskaya, E., Schweizer, C. \& Nieuwenhuijsen, M.J. (2006) Determinants of indoor air concentrations of PM2.5, black smoke and NO2 in six European cities (EXPOLIS study). Atmospheric Environment 40, 1299-1313. 
Lara, L.L., Artaxo, P., Martinelli, L.A., Camargo, P.B., Victoria, R.L. \& Ferraz, E.S.B. (2005) Properties of aerosols from sugar-cane burning emissions in Southeastern Brazil. Atmospheric Environment 39, 4627-4637.

Latza, U., Gerdes, S. \& Baur, X. (2009) Effects of nitrogen dioxide on human health: Systematic review of experimental and epidemiological studies conducted between 2002 and 2006. International Journal of Hygiene and Environmental Health 212, 271-287.

Lemieux, P.M., Lutes, C.C. \& Santoianni, D.A. (2004) Emissions of organic air toxics from open burning: a comprehensive review. Progress in Energy and Combustion Science 30, 1-32.

Lewné, M., Cyrys, J., Meliefste, K., Hoek, G., Brauer, M., Fischer, P., Gehring, U., Heinrich, J., Brunekreef, B. \& Bellander, T. (2004) Spatial variation in nitrogen dioxide in three European areas. Science of The Total Environment 332, 217-230.

Lewtas, J. (2007) Air pollution combustion emissions: Characterization of causative agents and mechanisms associated with cancer, reproductive, and cardiovascular effects. Mutation Research/Reviews in Mutation Research 636, 95-133.

Ma, T.H. (1981) Tradescantia micronucleus bioassay and pollen tube chromatid aberration test for in situ monitoring and mutagen screening. Environmental Health Perspectives 37, 85-90.

Ma, T.H., Cabrera, G.L., Chen, R., Gill, B.S., Sandhu, S.S., Vandenberg, A.L. \& Salamone, M.F. (1994a) Tradescantia micronucleus bioassay. Mutation Research/Fundamental and Molecular Mechanisms of Mutagenesis 310, 221-230. 
Ma, T.H., Cabrera, G.L., Chen, R., Gill, B.S., Sandhu, S.S., Vandenberg, A.L. \& Salamone, M.F. (1994b) Tradescantia micronucleus bioassay. Mutation research 310, 221-230.

MacGregor, J.T., Heddle, J.A., Hite, M., Margolin, B.H., Ramel, C., Salamone, M.F. \& Tice, R.R., Wild, D. (1987) Guidelines for the conduct of micronucleos assays in mammalian bone marrow erytrocytes. Matat. Res. 189, $103-112$.

Makkonen, U., Hellén, H., Anttila, P. \& Ferm, M. (In press) Size distribution and chemical composition of airborne particles in south-eastern Finland during different seasons and wildfire episodes in 2006. Science of The Total Environment 408, 644-651.

Malling, H.V. (2004) Incorporation of mammalian metabolism into mutagenicity testing. Mutation research 566, 183-189.

Mariani, R.L., Martins Jorge, M.P., Pereira, S.S., Melione, L.P., Carvalho-Oliveira, R., Ma, T.H. \& Nascimento Saldiva, P.H. (2009) Association between micronuclei frequency in pollen mother cells of Tradescantia and mortality due to cancer and cardiovascular diseases: A preliminary study in Sao José dos Campos, Brazil. Environmental Pollution 157, 1767-1770.

McMurry, P.H. (2000) A review of atmospheric aerosol measurements. Atmospheric Environment 34, 1959-1999.

McNeilly, J.D., Heal, M.R., Beverland, I.J., Howe, A., Gibson, M.D., Hibbs, L., MacNee, W. \& Donaldson, K. (2004) Soluble transition metals cause the proinflammatory effects of welding fumes in vitro. In: Toxicology and Applied Pharmacology 196, 95-107 DOI: 10.1016/j.taap.2003.11.021 (

Medeiros, J.N., Rivero, D.H.R.F., Kasahara, D.I., Saiki, M., Godleski, J.J., Koutrakis, P., Capelozzi, V.L., Saldiva, P.H.N. \& Antonangelo, L. (2004) Acute pulmonary and hematological effects of two types of particle 
surrogates are influenced by their elemental composition. Environmental Research 95, 62-70.

Meireles, J., Rocha, R., Neto, A.C. \& Cerqueira, E. (2009) Genotoxic effects of vehicle traffic pollution as evaluated by micronuclei test in tradescantia (TradMCN). Mutation Research/Genetic Toxicology and Environmental Mutagenesis 675, 46-50.

Mielli, A.C., Matta, M.E.M., Nersesyan, A., Saldiva, P.H.N. \& Umbuzeiro, G.A. (2009) Evaluation of the genotoxicity of treated urban sludge in the Tradescantia micronucleus assay. Mutation Research/Genetic Toxicology and Environmental Mutagenesis 672, 51-54.

Misík, M., Micieta, K., Solenská, M., Misíková, K., Pisarcíková, H. \& Knasmüller, S. (2007) In situ biomonitoring of the genotoxic effects of mixed industrial emissions using the Tradescantia micronucleus and pollen abortion tests with wild life plants: Demonstration of the efficacy of emission controls in an eastern European city. Environmental Pollution 145, 459-466.

Molina, R., Moreno, I., Pichardo, S., Jos, A., Moyano, R., Monterde, J.G. \& Camean, A. (2005) Acid and alkaline phosphatase activities and pathological changes induced in Tilapia fish (Oreochromis sp.) exposed subchronically to microcystins from toxic cyanobacterial blooms under laboratory conditions. Toxicon 46, 725-735.

Morawska, L. \& Zhang, J. (2002) Combustion sources of particles. 1. Health relevance and source signatures. Chemosphere 49, 1045-1058.

Mortelmans, K. \& Zeiger, E. (2000) The Ames Salmonella/microsome mutagenicity assay. Mutation Research/Fundamental and Molecular Mechanisms of Mutagenesis 455, 29-60.

Muller, P., Stock, T., Bauer, S. \& Wolff, I. (2002) Genotoxicological characterisation of complex mixtures: Genotoxic effects of a complex mixture 
of perhalogenated hydrocarbons. Mutation Research/Genetic Toxicology and Environmental Mutagenesis 515, 99-109.

Nawrot, T.S., Kuenzli, N., Sunyer, J., Shi, T., Moreno, T., Viana, M., Heinrich, J., Forsberg, B., Kelly, F.J., Sughis, M., Nemery, B. \& Borm, P. (2009) Oxidative properties of ambient PM2.5 and elemental composition: Heterogeneous associations in 19 European cities. Atmospheric Environment 43, 4595-4602.

NEP/LPAE-FMUSP (2008) Manual de Instalação, Operação e Manutenção. Coletor de Material Particulado 1,8 LPM PM 2,5 Mini Sampler.

Ohe, T., Watanabe, T. \& Wakabayashi, K. (2004) Mutagens in surface waters: a review. Mutation Research/Reviews in Mutation Research 567, 109-149.

Oliveira, S.C.S. \& Rocha, A.G.P. (2009) Diagnóstico da cadeia produtiva do caju na bahia - potencial do território de identidade semiárido nordeste II. Revista Desenbahia $N^{\circ} 10$.

Phani Kumar, P., Paramashivappa, R., Vithayathil, P.J., Subba Rao, P.V. \& Srinivasa Rao, A. (2002) Process for isolation of cardanol from technical cashew (Anacardium occidentale L.) nut shell liquid. Journal of agricultural and food chemistry 50, 4705-4708.

Pires, J.C.M., Sousa, S.I.V., Pereira, M.C., Alvim-Ferraz, M.C.M. \& Martins, F.G. (2008) Management of air quality monitoring using principal component and cluster analysis--Part II: CO, NO2 and O3. Atmospheric Environment 42, 1261-1274.

Pope, C.A., Burnett, R.T., Thun, M.J., Calle, E.E., Krewski, D., Ito, K. \& Thurston, G.D. (2002) Lung cancer, cardiopulmonary mortality, and long-term exposure to fine particulate air pollution. JAMA : the journal of the American Medical Association 287, 1132-1141. 
Prajapati, S.K. \& Tripathi, B.D. (2008) Assessing the genotoxicity of urban air pollutants in Varanasi City using Tradescantia micronucleus (Trad-MCN) bioassay. Environment International 34, 1092-1096.

Querol, X., Alastuey, A., Rodriguez, S., Plana, F., Mantilla, E. \& Ruiz, C.R. (2001) Monitoring of PM10 and PM2.5 around primary particulate anthropogenic emission sources. Atmospheric Environment 35, 845-858.

Ramanathan, V. \& Feng, Y. (2009) Air pollution, greenhouse gases and climate change: Global and regional perspectives. Atmospheric Environment 43, 3750 .

Rank, J. (2003) The method of Allium Anaphase-Telophase chromosome aberration assay. Ekologija 1, 38-42.

Rank, J. \& Jensen, K. (2003) Comet assay on gill cells and hemocytes from the blue mussel Mytilus edulis. Ecotoxicology and Environmental Safety 54, 323329.

Remor, A.P., Totti, C.C., Moreira, D.A., Dutra, G.P., Heuser, V.D. \& Boeira, J.M. (2009) Occupational exposure of farm workers to pesticides: biochemical parameters and evaluation of genotoxicity. Environment International 35, 273-278.

Ribeiro, L.R., Salvadori, D.M.F. \& Marques, E.K. (2003) Mutagênese Ambiental. 173-200.

Savóia, E.J.L., Domingos, M., Guimarães, E.T., Brumati, F. \& Saldiva, P.H.N. (2009) Biomonitoring genotoxic risks under the urban weather conditions and polluted atmosphere in Santo André, SP, Brazil, through Trad-MCN bioassay. Ecotoxicology and Environmental Safety 72, 255-260. 
See, S.W. \& Balasubramanian, R. (2008) Chemical characteristics of fine particles emitted from different gas cooking methods. Atmospheric Environment 42, 8852-8862.

Silmara de Moraes, P., Ayda Vera, A., José do Patrocínio Hora, A. \& Mário Antônio, S. (2006) The piscine micronucleus test to assess the impact of pollution on the Japaratuba river in Brazil. Environ Mol Mutagen 47, 219-224.

Simoneit, B.R.T. (2002) Biomass burning -- a review of organic tracers for smoke from incomplete combustion. Applied Geochemistry 17, 129-162.

Souza, T.S. \& Fontanetti, C.S. (2006) Micronucleus test and observation of nuclear alterations in erythrocytes of Nile tilapia exposed to waters affected by refinery effluent. Mutation Research/Genetic Toxicology and Environmental Mutagenesis 605, 87-93.

Stich, H.F., San, R.H. \& Rosin, M.P. (1983) Adaptation of the DNA-repair and micronucleus tests to human cell suspensions and exfoliated cells. Annals of the New York Academy of Sciences 407, 93-105.

Tolbert, P.E., Shy, C.M. \& Allen, J.W. (1992) Micronuclei and other nuclear anomalies in buccal smears: methods development. Mutation Research/Environmental Mutagenesis and Related Subjects 271, 69-77.

Umbuzeiro, G.d.A., Kummrow, F.b., Roubicek, D.A. \& Tominaga, M.Y. (2006a) Evaluation of the water genotoxicity from Santos Estuary (Brazil) in relation to the sediment contamination and effluent discharges. Environment international 32, 359-364.

Umbuzeiro, G.d.A., Warren, S.H. \& Claxton, L.D. (2006b) The mutation spectra of chlorinated drinking water samples using the base-specific TA7000 strains of Salmonella in the. Mut.Res.-Genetic Toxicology and Environmental Mutagenesis 609, 26-33. 
Umbuzeiro, G.d.A., Roubicek, D.A., Rech, C.M., Sato, M.I.Z. \& Claxton, L.D. (2004) Investigating the sources of the mutagenic activity found in a river using the Salmonella assay and different water extraction procedures. Chemosphere 54, 1589-1597.

USEPA, U.S.E.P.A. (1998) How Nitrogen Oxides Affect the Way We Live and Breathe. Office of Air Quality Planning and Standards, Washington, DC Publication EPA-456/F-98-005.

Villela, I.V., de Oliveira, I.M., da Silva, J. \& Henriques, J.A.P. (2006) DNA damage and repair in haemolymph cells of golden mussel (Limnoperna fortunei) exposed to environmental contaminants. Mutation research 605, 78-86.

Ward, D.E. \& Hardy, C.C. (1991) Smoke emissions from wildland fires. Environment International 17, 117-134.

Ward, T. \& Noonan, C. (2008) Results of a residential indoor PM<sub $>2.5</$ sub $>$ sampling program before and after a woodstove changeout. Indoor Air 18, 408-415.

White, P.A. \& Rasmussen, J.B. (1998) The genotoxic hazards of domestic wastes in surface waters. Mutation Research/Reviews in Mutation Research 410, 223-236.

WHO (2003) Health Aspects of Air Pollution with Particulate Matter, Ozone and Nitrogen Dioxide. Report on a WHO Working Group.

WHO (2004) Urban air pollution. Comparative Quantification of Health Risks, Chapter 17.

WHO (2005a) Air quality guidelines for particulate matter, ozone, nitrogen dioxide and sulfur dioxide. Summary of risk assessment Global update 2005:22. 
WHO (2005b) WHO Air quality guidelines for particulate matter, ozone, nitrogen dioxide and sulfur dioxide. Summary of risk assessment - Global update 2005, 22.

Wu, J.-Y. (2005) Assessing surface water quality of the Yangtze Estuary with genotoxicity data. Marine Pollution Bulletin 50, 1661-1667.

Yamasoe, M.A., Artaxo, P., Miguel, A.H. \& Allen, A.G. (2000) Chemical composition of aerosol particles from direct emissions of vegetation fires in the Amazon Basin: water-soluble species and trace elements. Atmospheric Environment 34, 1641-1653.

Yang, W. \& Omaye, S.T. (2009) Air pollutants, oxidative stress and human health. Mutation Research/Genetic Toxicology and Environmental Mutagenesis 674, 45-54.

Zagatto, P.A. \& Bertoletti, E. (2006) Ecotoxicologia Aquática - Principios e Aplicações. 478.

Zanobetti, A. \& Schwartz, J. (2006) Air pollution and emergency admissions in Boston, MA. Journal of epidemiology and community health 60, 890-895.

\subsection{Referências eletrônicas}

CETESB. Companhia Ambiental do Estado de São Paulo. Secretaria de Estado do Meio Ambiente. (http://www.cetesb.sp.gov.br/Ar/ar_saude.asp\#ozonio). Acessado em 08/12/2009.

DATASUS. Ministério da Saúde, Departamento de Informática do SUS. (2008). http://portal.saude.gov.br/portal/aplicacoes/tabfusion/tabfusion.cfm. Acessado em 10/10/2009. 
EMPARN. Empresa de Pesquisa Agropecuária do RN. http://www.emparn.rn.gov.br/contentproducao/aplicacao/emparn/principal/enviado s/index.asp. Acessado 08/09/2009.

FAO. FOOD AND AGRICULTURE ORGANIZATION OF THE UNITED NATIONS. Key statistics of food and agriculture external trade. Available at http://faostatfaoorg. 2008; Acessado em 17/06/2009.

IBGE. Instituto Brasileiro de Geografia e Estatística (2009) Indicadores Agropecuários. http://www.ibge.gov.br/home/estatistica/. Acessado em 10/10/2009.

IBGE. Instituto Brasileiro de Geografia e Estatística (2007). IBGE Cidades http://www.ibge.gov.br/cidadesat/topwindow.htm?1. Acessado em 10/10/2009.

IBGE. Instituto Brasileiro de Geografia e Estatística (2006). IBGE Cidades http://www.ibge.gov.br/cidadesat/topwindow.htm?1. Acessado em 10/10/2009.

ONU. (1992) Protocolo de Quioto à Convenção-Quadro das Nações Unidas sobre Mudança do Clima. http://www.onu-brasil.org.br/doc quioto.php. Acessado em 15/11/2009.

Porpino I. 2006. RN registra aumento de $28,3 \%$ no trabalho infantil. Tribuna do Norte. $\quad$ http://pfdc.pgr.mpf.gov.br/clipping/pdfs/outubro/clipping 26out 06.pdf. Acessado em 14/10/2009.

USDA. United States Department of Agriculture (2007). Germplasm Resources Information Network. http://www.ars-grin.gov/cgi-bin/npgs/html/taxon.pl?407023. Acessado em 10/12/2009. 


\section{ANEXOS}

Anexo I. Correlação de Spearman por ponto para os elementos: $\mathrm{O}_{3}$ e $\mathrm{NO}_{2} ; \mathrm{MP}$ e $B C$.

\begin{tabular}{lcc}
\hline Elemento & O3 X NO2 & MP X BC \\
\hline Ponto 1 & $-0,74$ & 0,66 \\
Ponto 2 & $-0,21$ & 0,18 \\
Ponto 3 & $-0,26$ & 0,59 \\
\hline
\end{tabular}

Anexo II. Os dados de precipitação correspondem ao resultado total mensal em milímetros $(\mathrm{mm})$. A direção dos ventos corresponde aos sentidos predominantes ordenados do mais freqüente para o menos. A velocidade média mensal dos ventos é apresentada em metros por segundos $(\mathrm{m} / \mathrm{s})$.

\begin{tabular}{|c|c|c|c|c|c|c|c|c|}
\hline & \multicolumn{2}{|c|}{$\begin{array}{c}\text { Setembro - } \\
2008\end{array}$} & \multicolumn{2}{|c|}{ Janeiro - 2009} & \multicolumn{2}{|c|}{ Maio - 2009} & \multicolumn{2}{|c|}{$\begin{array}{l}\text { Setembro - } \\
2009\end{array}$} \\
\hline & Ponto & Ponto & Ponto & Ponto & Ponto & Ponto & Ponto & Ponto \\
\hline & 1 e 2 & 3 & 1 e 2 & 3 & 1 e 2 & 3 & 1 e 2 & 3 \\
\hline Precipitação & 24,9 & 37,8 & 103,5 & 55,4 & 328,5 & 104,8 & 57,8 & 29,6 \\
\hline $\begin{array}{l}\text { Direção dos } \\
\text { ventos }\end{array}$ & SE, E & SE, S & SE, E & SE, E & $\mathrm{E}, \mathrm{SE}$ & SE, E & $\mathrm{SE}, \mathrm{E}$ & SE, E \\
\hline Velocidade & 4,2 & 5,2 & 3,5 & 3,9 & 2,3 & 4,6 & 2,8 & 4,6 \\
\hline
\end{tabular}

Ponto 1 e 2: Instituto Nacional de Meteorologia - INMET.

Ponto 3: Estação Meteorológica da UFRN. 


\section{Anexo III. Comitê de ética em Pesquisa.}

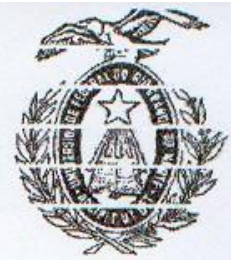

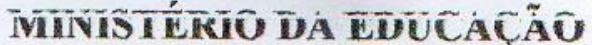

UNIVERSIDADE FEDERAL DO RIO GRANDE DO NORTE

COMTTÉ DE ETICA EM PESOUISA DO HOSPITAL

UNIYERSITÁDIO ONOFRE IOPES (CEP-HUOL)

\section{CERTIFICADO}

O Comitê de Etica em Pesquisa do Hospital Universitário Onofre Lopes (CEP-HUOL), devidamente reconhecido pela Comissão Nacional de Ética em Pesquisa (CONEP/MS), analisou o projeto:

IItulo: Avalıaçao da toxıcıdade da poluıçao por materıal partıcuiado gerado por diterentes tontes emissoras: proposição de estudos clínicos e experimentais. - Protocolo - 075/07

Pesquisador Responsável: Silvia Regina Batistuzzo de Medeiros.

Este projeto foi aprovado em seus aspectos éticos e metodológicos, incluindo o termo de consentimento IIvre e esclarecido, de acordo com as diretrizes da Kesoluçao 196/46 e complementares, do Conselho Nacional de Saúde, em reunião plenária do CEP-HUOL realizada no dia 05 de julho de 2007. Toda e qualquer alteração no projeto/protocolo de pesquisa, assim como eventos adversos que venham a ocorrer deveräo ser comunicados oficialmente $\theta$ imediatamente ao CEP-HUOL. O relatório final do projeto ou a cópia de sua publicação deverá ser encaminhado ao LEHIHUUL apos o termino do estudo, contorme cronograma, com a respectiva copia da tolna de rosto.

Natal, 05 de julho de 2007.

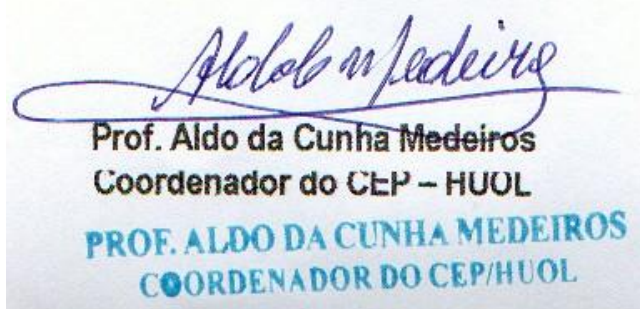

Comitê de Ética em Pesquisa do Hospital Universitário Onofre Lopes (CEP-HUOL) - Av. Nilo Peçanha 620, Petrópolis, Natal-RN, 59.012-300. Fone: 84-32023719 Ramal 242. email:cep_huol@yahoo.com.br 


\section{Anexo IV. Termo de consentimento livre e esclarecido da UFRN}

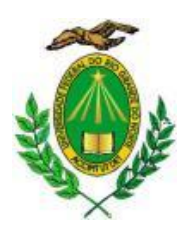

\section{UNIVERSIDADE FEDERAL DO RIO GRANDE DO NORTE} CENTRO DE BIOCIENCIAS

DEPARTAMENTO DE BIOLOGIA CELULAR E GENÉTICA

Cep - 59.015-310. Natal, RN, Brasil.

Tel. (84) 32119209 Fax. (84) 32153346.

\section{TERMO DE CONSENTIMENTO LIVRE E ESCLARECIDO}

$\mathrm{Eu}$, na qualidade de sujeito da pesquisa científica assino este termo ou coloco minha impressão datiloscópica como sinal de concordância e permito que meus dados sejam usados para fins dessa pesquisa científica sob o Título do Projeto: Avaliação da toxicidade da poluição por material particulado gerado por diferentes fontes emissoras: proposição de estudos clínicos e experimentais. FUI DEVIDAMENTE ESCLARECIDO SOBRE:

RISCOS: A colocação de aparelhos para medição de pressão arterial e eletrocardiograma não trazem riscos à saúde. Podem eventualmente trazer um desconforto momentâneo, quando o manguito do aparelho de tempo em tempo comprime o braço para medir a pressão arterial. A coleta de sangue será feita por profissionais experientes e materiais estéreis e descartáveis serão utilizados, dessa forma não representa risco à saúde. Haverá desconforto pela dor mínima provocada pela punção da veia para retirada de sangue. A verificação de micronúcleo com material de mucosa oral não oferece risco à saúde, sendo realizado com o auxilio de um abaixador de língua descartável, onde o leve atrito entre o abaixador e a mucosa oral é suficiente para a preparação da lâmina.

BENEFÍCIOS: Os dados coletados ajudarão a compreensão dos efeitos da poluição do ar sobre a saúde, contribuindo na tentativa de controle da poluição do ar na atividade da queima da castanha de caju.

ESTUDO CONFIDENCIAL: Todos os dados obtidos neste estudo serão mantidos em sigilo e não serão disponibilizados para terceiros nem utilizados para outros fins que não os da pesquisa, sem o seu expresso consentimento. Se qualquer relatório ou publicação resultar deste trabalho, a identificação do paciente não será revelada. Resultados serão relatados de forma sumariada e a pessoa não será identificada.

PARTICIPACÃO VOLUNTÁRIA: Toda participação é voluntária. Não há penalidade para alguém que decida não participar neste estudo. Ninguém será penalizado se decidir desistir de participar do estudo, em qualquer época. Podendo retirar-se da participação da pesquisa, sem correr riscos e sem prejuízo pessoal.

ESCLARECIMENTOS E PERGUNTAS: O participante poderá obter qualquer informação ou esclarecimentos, antes, durante ou após a pesquisa, e ainda a garantia de tomar conhecimento, dos resultados parciais e finais do projeto mediante contato com o Dra. Silvia Regina Batistuzzo de Medeiros (084)3215 3346, professora do Departamento de Biologia Celular e Genética da UFRN.

CONSENTIMENTO PARA PARTICIPACÃO: Eu estou de acordo com a participação no estudo descrito acima, me submeto à participação nessa pesquisa científica. Eu fui devidamente esclarecido quanto aos objetivos da pesquisa, aos procedimentos aos quais serei submetido e os possíveis riscos envolvidos na minha participação. Os pesquisadores me garantiram disponibilizar qualquer esclarecimento adicional que eu venha a solicitar 
durante o curso da pesquisa e o direito de desistir da participação em qualquer momento, sem que a minha desistência implique em qualquer prejuízo a minha pessoa ou a minha família. A minha participação na pesquisa é voluntária, e não me implicará em custos ou prejuízos adicionais, sejam esses custos ou prejuízos de caráter econômico, social, psicológico ou moral, sendo garantido o anonimato e o sigilo dos dados referentes à minha identificação.

Assinatura do sujeito: ; Testemunha:

Assinatura do responsável pela pesquisa:

\section{COMPROMISSO DO PESQUISADOR:}

Eu, Thiago de Melo Cabral, discuti e expus todas as questões acima apresentadas com cada participante no estudo ou com o seu representante legalmente autorizado. É minha opinião que cada indivíduo entende os riscos, benefícios e obrigações relacionadas a esta pesquisa.

João Câmara, Data:

Assinatura do Pesquisador

Endereço do pesquisador:

R. Jacarandá, n. 227, Nova Parnamirim, Parnamirim/RN, CEP:.59150-000

Tel. (84) 36084561 Cel. (84) 8803 6991; e mail:cabral@usp.br 


\title{
HOSPITAL DAS CLÍNICAS DA FACULDADE DE MEDICINA DA UNIVERSIDADE DE SÃO PAULO-HCFMUSP
}

\author{
MODELO DE TERMO DE CONSENTIMENTO LIVRE E ESCLARECIDO
}

\section{DADOS DE IDENTIFICAÇÃO DO SUJEITO DA PESQUISA OU RESPONSÁVEL LEGAL}

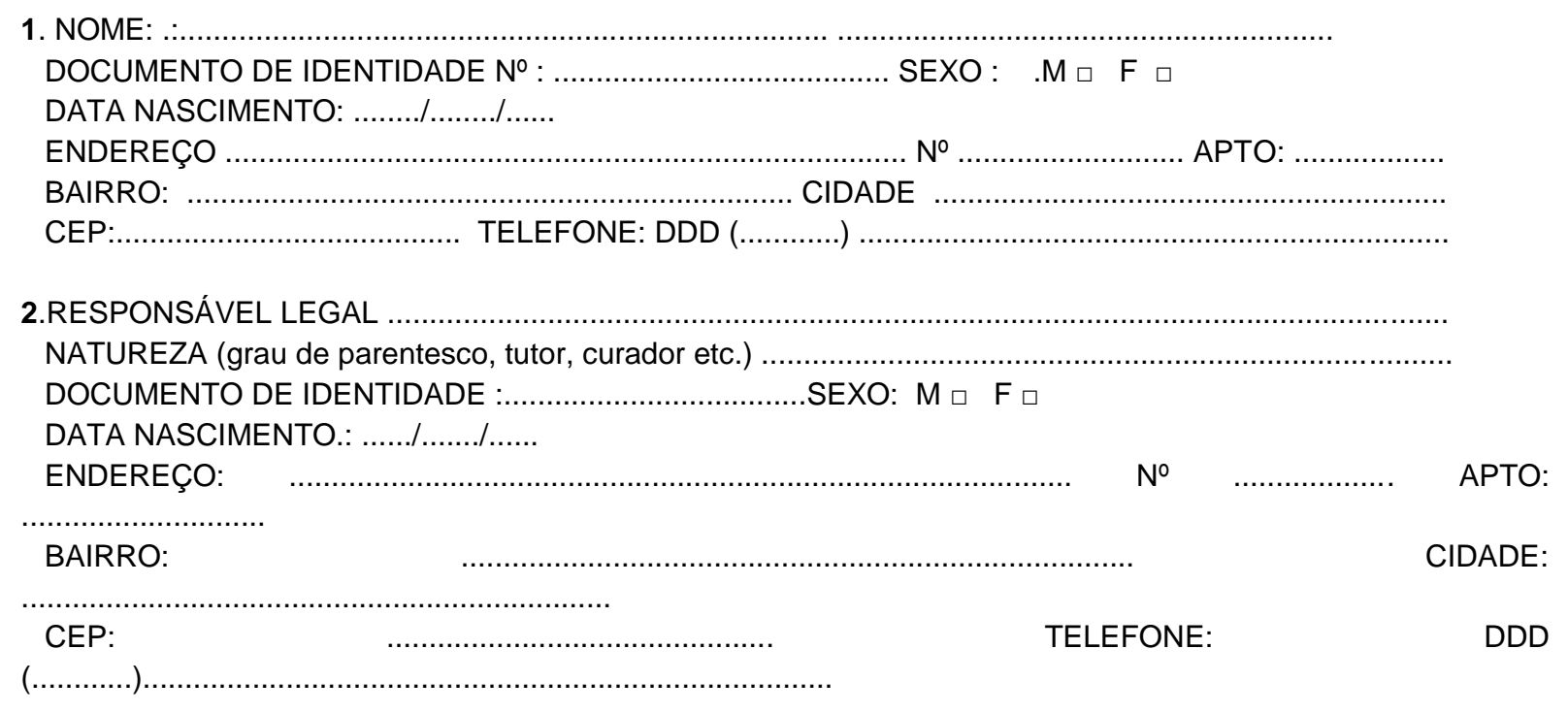

\section{DADOS SOBRE A PESQUISA}

1. TíTULO DO PROTOCOLO DE PESQUISA: Avaliação das alterações respiratórias e mutagênese em trabalhadores envolvidos na queima da castanha de caju PESQUISADOR : M.Sc. Thiago de Melo Cabral CARGO/FUnÇÃO: Doutorando do Programa de Pós-Graduação em Ciências PATOLOGIA. INSCRIÇÃO CONSELHO REGIONAL № Biólogo UNIDADE DO HCFMUSP: Departamento de Patologia 3. AVALIAÇÃO DO RISCO DA PESQUISA:

$$
\begin{array}{ll}
\text { RISCO MÍNIMO } & \text { RISCO MÉDIO } \\
\text { RISCO BAIXO } \square & \text { RISCO MAIOR }
\end{array}
$$




\section{hOSPITAL dAS CLÍNICAS DA FACULdADE DE MEDICINA DA UNIVERSIDADE DE SÃO PAULO-HCFMUSP}

1 - Desenho do estudo e objetivo(s)

Essas informações estão sendo fornecidas para sua participação voluntária neste estudo, que visa - "Avaliar os efeitos da fumaça produzida durante a queima da castanha de caju nas pessoas. Essas avaliações representam uma forma de tentar entender possíveis riscos que podem está relacionada com a fumaça".

2 - Descrição dos procedimentos que serão realizados, com seus propósitos e identificação dos que forem experimentais e não rotineiros;

Serão coletados sangue e raspado da boca (mucosa oral) para análises. Esses exames serão realizados para detectar eventuais alterações provocadas pela poluição do ar nas células do sangue e da boca.

Não há procedimento experimental

3 - Relação dos procedimentos rotineiros e como são realizados

a. Coleta de sangue do antebraço;

b. Coleta de raspado de mucosa oral com o auxílio de abaixador de língua (Semelhante ao palito de picolé).

4 - Descrição dos desconfortos e riscos esperados nos procedimentos dos itens 2 e 3;

A coleta de sangue será feita por profissionais experientes e materiais estéreis e descartáveis serão utilizados, dessa forma não representa risco à saúde. Haverá desconforto pela dor mínima provocada pela picada da agulha (punção da veia para retirada de sangue). $\mathrm{A}$ análise das células da boca não oferece risco à saúde, sendo realizado com o auxilio de um abaixador de língua descartável (Semelhante ao palito de picolé), onde o leve contato entre o abaixador e a mucosa oral é suficiente para o exame.

5 - Benefícios para o participante

Não há benefício direto para o participante. Os dados coletados ajudarão a compreensão dos efeitos da poluição do ar sobre a saúde, e ao final do estudo, caso seja comprovado o efeito lesivo da atividade, poderá ser proposto medidas que visem auxiliar na tentativa 
de controle da poluição do ar na atividade da queima da castanha de caju ou diminuir a exposição humana aos poluentes.

6 - Relação de procedimentos alternativos que possam ser vantajosos, pelos quais o paciente pode optar;

Não haverá procedimento alternativo.

7 - Garantia de acesso: em qualquer etapa do estudo, você terá acesso aos profissionais responsáveis pela pesquisa para esclarecimento de eventuais dúvidas. O principal investigador é o Dr Paulo Hilário Nascimento Saldiva que pode ser encontrado no endereço Av. Dr. Arnaldo, 455 10. andar s/1155, Cerqueira César, São Paulo, SP, CEP 01246-903, Faculdade de Medicina da USP, Departamento de Patologia, Telefone (11) 3061-7254. Se você tiver alguma consideração ou dúvida sobre a ética da pesquisa, entre em contato com o Comitê de Ética em Pesquisa (CEP) - Rua Ovídio Pires de Campos, 225 - 5o andar - tel: 3069-6442 ramais 16, 17, 18 ou 20, FAX: 3069-6442 ramal 26 - E-mail: cappesq@ honet.usp.br

8 - É garantida a liberdade da retirada de consentimento a qualquer momento e deixar de participar do estudo, sem qualquer prejuízo à continuidade de seu tratamento na Instituição;

09 - Direito de confidencialidade - As informações obtidas serão analisadas em conjunto com outros pacientes, não sendo divulgado a identificação de nenhum paciente; 10 - Direito de ser mantido atualizado sobre os resultados parciais das pesquisas, quando em estudos abertos, ou de resultados que sejam do conhecimento dos pesquisadores;

11 - Despesas e compensações: não há despesas pessoais para o participante em qualquer fase do estudo, incluindo exames e consultas. Também não há compensação financeira relacionada à sua participação. Se existir qualquer despesa adicional, ela será absorvida pelo orçamento da pesquisa. 12 - Compromisso do pesquisador de utilizar os dados e o material coletado somente para esta pesquisa.

Acredito ter sido suficientemente informado a respeito das informações que li ou que foram lidas para mim, descrevendo o estudo" Avaliação das alterações respiratórias e mutagênese em trabalhadores envolvidos na queima da castanha de caju". 
Eu discuti com o Thiago de Melo Cabral sobre a minha decisão em participar nesse estudo. Ficaram claros para mim quais são os propósitos do estudo, os procedimentos a serem realizados, seus desconfortos e riscos, as garantias de confidencialidade e de esclarecimentos permanentes. Ficou claro também que minha participação é isenta de despesas e que tenho garantia do acesso a tratamento hospitalar quando necessário. Concordo voluntariamente em participar deste estudo e poderei retirar o meu consentimento a qualquer momento, antes ou durante o mesmo, sem penalidades ou prejuízo ou perda de qualquer benefício que eu possa ter adquirido, ou no meu atendimento neste Serviço.

Assinatura do paciente/representante legal Data 111

Assinatura da testemunha

Data

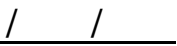

para casos de pacientes menores de 18 anos, analfabetos, semi-analfabetos ou portadores de deficiência auditiva ou visual.

(Somente para o responsável do projeto)

Declaro que obtive de forma apropriada e voluntária o Consentimento Livre e Esclarecido deste paciente ou representante legal para a participação neste estudo. 
Anexo VI. Questionário informativo sobre hábitos pessoais.

\section{UNIVERSIDADE FEDERAL DO RIO GRANDE DO NORTE CENTRO DE BIOCIÊNCIAS}

\section{QUESTIONÁRIO}

Leia e responda cuidadosamente as seguintes questões. A informação dada por você não será associada com o seu nome, sendo conhecida apenas pelos pesquisadores associados a este estudo. As respostas deste questionário poderão ter influência direta na interpretação de nossos resultados.

1-Endereço para correspondência:

2-Idade: em anos

3-Data de nascimento:

4-Sexo: ( ) Masculino ( ) Feminino

6-Estado civil:

8-Número de filhos naturais:

9-Qual o seu local de trabalho?

10-Há quanto tempo você trabalha neste local?

11-Qual a sua jornada de trabalho?

18-Passui o hábito de fumar? ( ) sim ( ) não

23-Foi ao dentista na última semana? ( ) sim ( ) não / ( ) raio-X; ( ) obturação; ( ) limpeza; ( ) tratamento de canal; ( ) clareamento; ( ) outros:

24-Consome bebidas alcoólicas? ( ) sim ( ) não - Qual? Freqüência:

32-Histórico de aborto espontâneo? ( ) sim ( ) não 34-Casos de câncer na família: ( ) sim ( ) não - grau de parentesco - 
35-Tipos de cânceres: ( ) pele; ( ) pulmão; ( ) mama; ( ) leucemia; ( ) cabeça e pescoço; ( ) outros -

Data

Assinatura do pesquisador responsável 